\title{
SUPRIMENTO DE BORO E ZINCO PARA CULTIVARES DE TRIGO: EM SOLUÇÃO NUTRITIVA E EM DOIS TIPOS DE SOLO
}

\author{
AMOACY CARVALHO FABRICIO \\ ENGENHEIRO-AGRÔNOMO
}

Orientador: Prof. Dr. ANTONIO ROQUE DECHEN

Tese apresentada à Escola Superior de Agricultura "Luiz de Queiroz", da Universidade de São Paulo, para obtenção do título de Doutor em Agronomia, Área de Concentração: Solos e Nutrição de Plantas.

\section{PIRACICABA}

Estado de São Paulo - Brasil

Agosto - 1994 
Fabricio, Amoacy Carvalho

Suprimento de boro e $z$ inco para cultivares de trigo: em solução nutritiva e em dois tipos de so 1o. Piracicaba, 1994. $92 \mathrm{p}$.

Tese - ESALQ

Bibliografia.

1. Nutriente em trigo 2. Trigo - Nutrição I. Escola Superior de Agricultura Luiz de Queiroz, Piracicaba. 


\title{
SUPRIMENTO DE BORO E ZINCO PARA CULTIVARES DE TRIGO: EM SOLUÇÃO NUTRITIVA E EM DOIS TIPOS DE SOLO
}

\author{
AMOACY CARVALHO FABRICIO
}

Aprovado em: 18.11 .94

Comissão julgadora:

Prof. Dr. Antonio Roque Dechen

ESALQ/USP

Prof. Dr. Ronaldo Ivan Silveira

ESALQ/USP

Prof. Dr. Francisco Antonio Monteiro

ESALQ/USP

Dr. José Ubirajara Garcia Fontoura

EMBRAPAVPAO

Dr. Manoel Dornelas de Souza
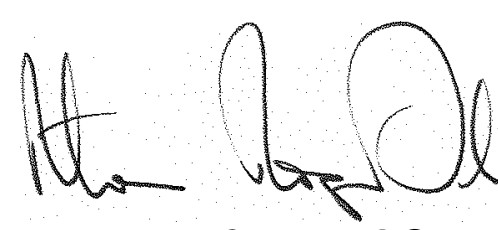

Prof. Dr. ANTONIO ROQUE DECHEN Orientador 
Aos meus pais ULYSSES (in memoriam) EVINHA

À minha esposa VIRGíNIA

Aos meus filhos ULYSSES

FABRICIO, 


\section{AGRADECIMENTOS}

Ao Professor Antonio Roque Dechen, pela orientação, apoio e amizade; Ao colega José Ubirajara Garcia Fontoura pelo incentivo e amizade;

À Empresa Brasileira de Pesquisa Agropecuária - EMBRAPA, pela liberação e apoio para a realização do curso de pós-graduação;

Ao Conselho Nacional de Desenvolvimento Científico e Tecnológico - CNPq, pela ajuda financeira;

Ao Departamento de Química da ESALQ, nas pessoas dos Professores Quirino A. de C. Carmello e Francisco A. Monteiro e aos Técnicos de Laboratório Lucia H. S. P. Forte, Lourdes A. D. de Gonzalez, Mirtes V. Sesso, Ednéia C. S. Mondoni, Nivanda M. A. C. Bovi e Fernando E. Ré, pelas facilidades e ajudas oferecidas na condução dos experimentos e nas determinações dos nutrientes;

Às Bibliotecárias Eliana Marta Garcia Sabino (ESALQ) e Eli de Lourdes Vasconcelos (CPAO) pelo auxilio na citação bibliográfica;

Aos colegas Manoel Dornelas de Souza e Rita Carla Boeira pela amizade, companheirismo e colaboração durante o curso,

Ao colega Carlos Hissao Kurihara pela ajuda e realização das análises estatísticas;

À Ivanilde Dispato e Eliete do Nascimento Ferreira pela digitação e montagem deste trabalho;

Ao colega Fernando de Assis Paiva pela versão do resumo para o Inglês; e

Aos demais colegas do CPAO que de alguma maneira tenham contribuído para a realização deste trabalho. 


\section{SUMÁRIO}

\section{Página}

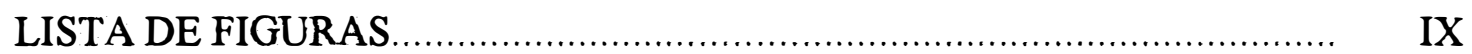

LISTA DE TABELAS ................................................................. X

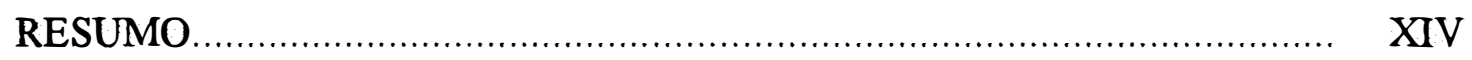

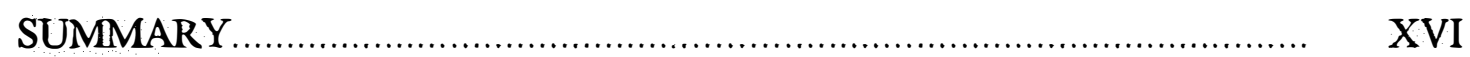

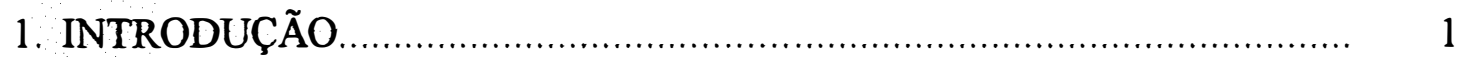

2. REVISÃO DE LITERATURA..................................................... 3

2.1. Solo ............................................................................... 3

2.1.1. Concentração e nível crítico de boro no solo ............................ 3

2.1.2. Concentração e nível crítico de zinco no solo........................... 4

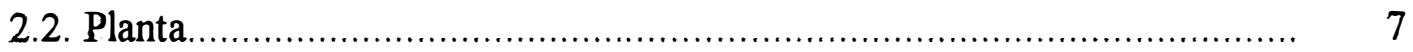

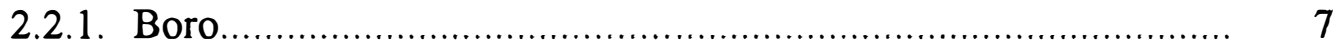

2.2.2. Zinco .................................................................... 8

2.3. Fatores que afetam a disponibilidade dos micronutrientes no solo ......... 10

2.3.1. Boro.................................................................... 10

2.3.2. Zinco ................................................................... 12

2.4. Exigências climáticas para a cultura do trigo.................................. 14 
Página

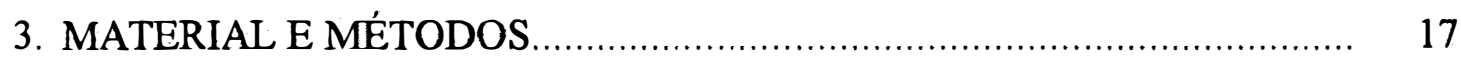

3.1. Experimentos em casa de vegetação................................................. 17

3.2. Experimentos em câmara de crescimento.............................................. 20

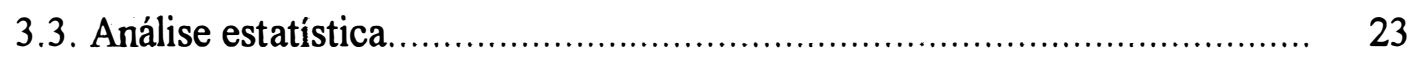

4. RESULTADOS E DISCUSSÃO

4.1. Experimentos em casa de vegetação.................................................... 25

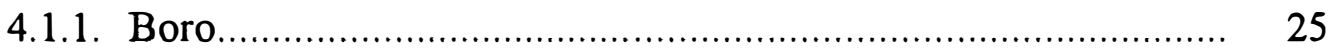

4.1.1.1. No solo ............................................................. 25

4.1.1.2. Na parte aérea da planta ........................................... 27

4.1.1.3. Componentes de produção .......................................... 28

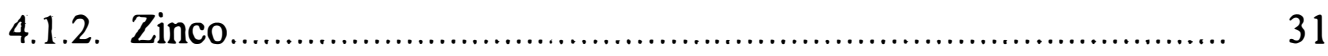

4.1.2.1. No solo ................................................................... 31

4.1.2.2. Na parte aérea da planta............................................. 33

4.1.2.3. Componentes de produção ........................................... 35

4.1.3. Fatores climáticos que influem na produção................................ 36

4.2. Experimentos em câmara de crescimento ............................................. 40

4.2.1. Boro

4.2.1.1. Comprimento da parte aérea e da raiz ......................... 40

4.2.1.2. Teor de boro na parte aérea e nas raízes....................... 44

4.2.1.3. Massa seca da parte aérea e das raízes.......................... 47

4.2.1.4. Acúmulo de boro na parte aérea e nas raízes................. 50

4.2.1.5. Eficiência de utilização de boro ...................................... 55 
Página

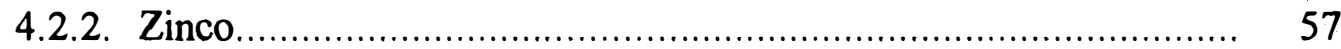

4.2.2.1. Comprimento da parte aérea e da raiz....................... 57

4.2.2.2. Teor de zinco na parte aérea e nas raízes.................... 59

4.2.2.3. Produção de massa seca da parte aérea e das raízes....... $\quad 64$

4.2.2.4. Acúmulo de zinco na parte aérea e nas raízes............... 65

4.2.2.5. Eficiência de utilização de zinco............................... 70

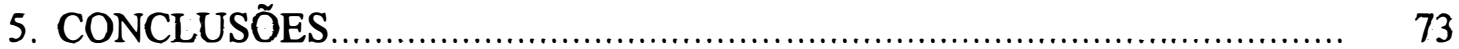

6. REFERÊNCIAS BIBLIOGRÁFICAS ........................................... 74

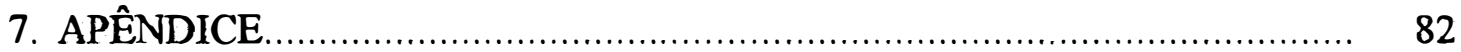




\section{LISTA DE FIGURAS}

Página

1. Teores de boro determinados em dois tipos de solo, em função da aplicação de níveis do nutriente.

2. Teores de boro na massa seca da palha das plantas em função dos níveis aplicados aos solos

3. Efeitos dos níveis de boro aplicados ao solo na produção de massa da palha de trigo no Latossolo Roxo distrófico.

4. Teores de zinco determinados em dois tipos de solo, em função da aplicação de níveis do nutriente

5. Teores de zinco na massa seca das plantas em função dos níveis aplicados aos solos

6. Temperaturas máximas e mínimas registradas no período de 15.05 .93 a 23.08 .93

7. Comprimento da parte aérea $(\mathrm{cm})$, em função dos níveis de boro

8. Teor de boro $(\mathrm{mg} / \mathrm{kg})$ na parte aérea em função dos níveis de boro

9. Acúmulo de boro na parte aérea em função dos níveis de boro

10. Acúmulo de boro nas raízes em função dos níveis de boro aplicados

11. Eficiência de utilização de boro pela parte aérea de cultivares de trigo

12. Teor de zinco na parte aérea, em função dos níveis de zinco

13. Teor de zinco nas raízes em função dos níveis de zinco.

14. Acúmulo de zinco na parte aérea das plantas de trigo

15. Acúmulo de zinco nas raízes das plantas de trigo

16. Eficiência de utilização de zinco pela parte aérea das plantas de trigo 


\section{LISTA DE TABELAS}

Página

1. Resultados das análises de terra das duas amostras de solos utilizadas nos experimentos

2. Composição das soluções estoques e da solução nutritiva usadas nos experimentos

3. Relação de cultivares de trigo usadas nos experimentos com boro e zinco em câmara de crescimento e seus respectivos ciclos

4. Teores de boro $(\mathrm{mg} / \mathrm{kg})$ no solo em função dos níveis de boro aplicados em dois tipos de solo (Latossolo Roxo distrófico - LRd e Latossolo VermelhoEscuro distrófico - LEd). Médias de quatro repetições.

5. Teores de boro $(\mathrm{mg} / \mathrm{kg})$ na massa seca das plantas em função dos níveis de boro aplicados em dois tipos de solo (Latossolo Roxo distrófico - LRd e Latossolo Vermelho-Escuro distrófico - LEd). Médias de quatro repetições.

6. Altura de planta, comprimento de espiga, número de grãos por espiga, massa de grãos e da palha em função dos níveis de boro nos dois tipos de solo: Latossolo Roxo distrófico - LRd e Latossolo Vermelho-Escuro distrófico - LEd. Médias de quatro repetições.

7. Teores de zinco (mg/kg) no solo em função dos níveis de zinco aplicados em dois tipos de solo (Latossolo Roxo distrófico - LRd e Latossolo Vermelho-Escuro distrófico - LEd). Médias de quatro repetições. 
8. Teores de zinco $(\mathrm{mg} / \mathrm{kg})$ na massa seca das plantas em função dos níveis de zinco aplicados em dois tipos de solo (Latossolo Roxo distrófico LRd e Latossolo Vermelho-Escuro distrófico - LEd). Médias de quatro repetições.

9. Altura de planta, comprimento de espiga, número de grãos por espiga, massa de grãos e da palha em função dos níveis de zinco nos dois tipos de solo: Latossolo Roxo distrófico - LRd e Latossolo Vermelho-Escuro distrófico - LEd. Médias de quatro repetições.

10. Equações de regressão e coeficientes de determinação $\left(R^{2}\right)$ entre os níveis de boro e o comprimento da parte aérea em cultivares de trigo

11. Comprimento da parte aérea em função dos níveis de boro. Médias de três repetições.

12. Comprimento das raízes $(\mathrm{cm})$ em função dos níveis de boro. Médias de três repetições

13. Equações de regressão e coeficientes de determinação $\left(R^{2}\right)$ entre níveis de boro e o teor do nutriente na parte aérea das plantas.

14. Produção de massa seca (g) da parte aérea das cultivares em função do uso de boro. Médias de três repetições.

15. Produção de massa seca (g) das raizes das cultivares em função dos niveis de boro. Médias de três repetições

16. Equações de regressão e coeficientes de determinação $\left(R^{2}\right)$ entre níveis $\mathrm{e}$ acúmulo de boro pela parte aérea 
17. Equações de regressão e coeficientes de determinação $\left(R^{2}\right)$ entre níveis e acúmulo de boro pelas raízes.

18. Acúmulo de boro nas raízes em função dos níveis de boro aplicados. Médias de três repetições.

19. Equações de regressão e coeficientes de determinação $\left(R^{2}\right)$ entre níveis e eficiência de utilização de boro pelas plantas.

20. Comprimento da parte aérea $(\mathrm{cm})$ das cultivares em função da aplicação de zinco. Médias de três repetições.

21. Comprimento das raízes $(\mathrm{cm})$ das cultivares em função da aplicação de zinco. Média de três repetições.

22. Equações de regressão e coeficientes de determinação $\left(R^{2}\right)$ entre níveis e eficiência de utilização de zinco pelas plantas.

23. Equações de regressão e coeficientes de determinação $\left(R^{2}\right)$ entre os níveis e o teor de zinco nas raízes.

24. Produção de massa seca da parte aérea (g), das cultivares em função da aplicação de zinco.

25. Produção de massa seca das raízes (g), das cultivares em função da aplicação de zinco.

26. Equações de regressão e coeficientes de determinação $\left(R^{2}\right)$ entre acúmulo de zinco na parte aérea e níveis de zinco na solução nutritiva.....

27. Equações de regressão e coeficientes de determinação $\left(R^{2}\right)$ entre acúmulo de zinco nas raízes e níveis de zinco na solução nutritiva. 
28. Equações de regressão e coeficientes de determinação $\left(R^{2}\right)$ entre níveis de zinco e acúmulo na parte aérea.

29. Eficiência de utilização [(g de $\left.\mathrm{MS})^{2 / m g} \mathrm{Zn}\right]$ pela parte aérea das plantas.. 


\title{
SUPRIMENTO DE BORO E ZINCO PARA CULTIVARES DE TRIGO: EM SOLUÇÃO NUTRITIVA E EM DOIS TIPOS DE SOLO
}

\author{
Autor: AMOACY CARVALHO FABRICIO \\ Orientador: Prof. DR. ANTONIO ROQUE DECHEN
}

\section{RESUMO}

O trigo é um cereal de grande importância na alimentação humana e no Brasil destaca-se como a principal cultura anual de inverno produzido nas Regiões Sul, Sudeste e Centro-Oeste. A produtividade da cultura está intimamente relacionada com a nutrição adequada das plantas e os micronutrientes têm importância relevante, já que são menos estudados que os macronutrientes. Partindo-se da hipótese que a produção de massa seca e absorção de nutrientes pela planta podem variar em cada cultivar e em tipos de solos, entende-se que maior conhecimento sobre esses assuntos facilitariam a recomendação de cultivares e doses de nutrientes em função da exigência dessas e o tipo de solo. Assim, realizaram-se experimentos em casa de vegetação com dois tipos de solo (Latossolo Roxo distrófico e Latossolo Vermelho-Escuro distrófico) e em câmara de crescimento, utilizando-se quatorze cultivares de trigo, avaliando-se diferentes níveis de cada nutriente (B e $\mathrm{Zn}$ ). Os experimentos com solo foram instalados em delineamento estatístico de blocos ao acaso com quatro repetições. Cada parcela constituiu-se de um vaso de plástico com 31 de terra. Os cinco níveis de cada elemento foram: boro 0,$0 ; 0,4$; 0,$8 ; 1,2$ e $1,6 \mathrm{mg} \mathrm{B} / \mathrm{dm}^{3}$ de terra na forma de $\mathrm{H}_{3} \mathrm{BO}_{3}$ e zinco 0,$0 ; 1,0 ; 2,0 ; 3,0$ e 4,0 mg $\mathrm{Zn} / \mathrm{dm}^{3}$ de terra na forma de $\mathrm{ZnCl}_{2}$. Usou-se a cultivar de trigo $\mathrm{BR}$ 18-Terena com seis plantas por vaso. Os experimentos em câmara de crescimento foram instalados em 
delineamento de blocos ao acaso com parcela subdividida com três repetições. As parcelas foram constituídas pelos quatro níveis dos nutrientes (boro: 0,$00 ; 0,25 ; 0,50 \mathrm{e}$ $1,25 \mathrm{mg} \mathrm{B} / \mathrm{l}$ e zinco: 0,$000 ; 0,025 ; 0,050$ e $0,100 \mathrm{mg} \mathrm{Zn} / \mathrm{l})$ e as subparcelas pelas quatorze cultivares de trigo. A adição de boro e zinco proporcionou aumento dos teores desses elementos nos solos e nas plantas, sem, no entanto, influir significativamente no rendimento de grãos. No Latossolo Roxo distrófico a adição de $0,8 \mathrm{mg} \mathrm{B} / \mathrm{dm}^{3}$ foi suficiente para obter rendimentos de massa seca de palha estatisticamente igual à dose máxima. Na câmara de crescimento as cultivares responderam de modo diferenciado à adição de boro e zinco. No experimento com boro, as cultivares BR 10-Formosa e BR 17-Caiuá foram mais eficientes que as demais na utilização do nutriente e, no experimento com zinco, as mais eficientes foram Anahuac e BR 18-Terena. Com relação à produção de massa seca da parte aérea e das raízes, as cultivares mais produtivas, no experimento com boro, foram IAC 18-Xavantes, BR 17-Caiuá, BR 20-Guató e BH 1146. No experimento com zinco, as mais produtivas foram BH 1146, IAC 18Xavantes e BR 31-Miriti. 


\title{
SUPPLY OF BORON AND ZINC FOR WHEAT CULTIVARS: IN NUTRITIVE SOLUTION AND ON TWO SOIL TYPES
}

\author{
Autor: AMOACY CARVALHO FABRICIO \\ Adviser: Prof. Dr. ANTONIO ROQUE DECHEN
}

\section{SUMMARY}

Wheat is a very important cereal as human food and in Brazil it stands out as the main winter crop at the South, Southest and Central West Regions. The crop yield is closely related to the apropriate plant nutrition and microelements are of utmost importance because they are less studied than the major ones. From the hypothesis that production of dry mass and absorption of elements by the plant may vary with the cultivars and the soil types, one understands that more knowledge about these matters would make recomendation of cultivars and dosage of nutrients easier. This is so because the nutrient dosage will be a function of the cultivars needs and the soil type chacteristics. Therefore experiments were carried out in greenhouse with two soil types (LRd and LEd) and growth chamber with fourteen wheat cultivars in order to evaluate levels of each element (B and $\mathrm{Zn}$ ). The experiments with soil were done using the statistical design of complete randomized blocks replicated four times. Each pot with 31 of soil was considered as a plot. The five levels of each element were: boron $=0.0 ; 0.4$; $0.8 ; 1.2$, and $1.6 \mathrm{mg}$ of $\mathrm{B} / \mathrm{dm}^{3}$ of soil as $\mathrm{H}_{3} \mathrm{BO}_{3}$ and zinc $=0.0 ; 1.0 ; 2.0 ; 3.0$, and 4.0 $\mathrm{mg}$ of $\mathrm{Zn} / \mathrm{dm}^{3}$ of soil as $\mathrm{ZnCl}_{2}$. The cultivar was "BR 18-Terena" with six plants in each 
pot. The experiments in the growth chamber were carried out in a split-plot complete randomized block design, replicated three times. The four nutrient levels (boron: 0.00; $0.25 ; 0.50$, and $1.25 \mathrm{mg}$ of $\mathrm{B} / \mathrm{l}$ and zinc: $0.000 ; 0.025 ; 0.050$, and $0.100 \mathrm{mg}$ of $\mathrm{Zn} / \mathrm{l}$ ) were the plots and the cultivars were the split-plots. Addition of boron and zinc increased the levels of the corresponding element in the soil and in the plants, without significantly influencing the grain yields. In the "Latossolo Roxo distrófico" type of soil the addition of $0.8 \mathrm{mg}$ of $\mathrm{B} / \mathrm{l}$ of soil was enough to reach dry mass yields statistically identical to maximum dosage. In the growth chamber the cultivars behaved differently to addition of both boron and zinc. With the boron experiment "BR 10-Formosa" and "BR 17-Caiuá" were the most efficient in the utilization of the nutrient, and with the zinc experiment the most efficient were "Anahuac" and "BR 18-Terena". As for the dry matter yield as shoots and roots, the most productive in the boron experiment, were "IAC 18-Xavantes", BR 17-Caiuá, "BR 20-Guató" and "BH 1146". With zinc experiment the most productive were "BH 1146", "IAC 18-Xavantes" and "BR 31Miriti". 


\section{INTRODUÇÃO}

O trigo (Triticum aestivum L.) é um cereal de grande importância na alimentação humana e ocupa os primeiros lugares dentre os cereais cultivados no mundo, com área plantada de 231,5 milhões de hectares e produção de 595,1 milhões de toneladas (FAO, 1991).

No Brasil, também é muito importante, e destaca-se como a principal cultura anual de inverno, ocupando 1,4 milhão de hectares e produzindo 2,2 milhões de toneladas (IBGE, 1993). Atualmente é cultivado nas Regiões Sul, Sudeste e CentroOeste, destacando-se os estados do Paraná, com 1,0 milhão de hectares e produção de 1,8 milhão de toneladas; Rio Grande do Sul, com 617,4 mil hectares e 682,6 mil toneladas; Mato Grosso do Sul, com 112,8 mil hectares e 155,9 mil toneladas e São Paulo, com 98,1 mil hectares e 141,7 mil toneladas de grãos (IBGE, 1993).

$\mathrm{Na}$ década de 80 e até atualmente tem ocorrido variações na área plantada, produção e produtividade dessa cultura. Essas variações têm sido em função, principalmente, das instabilidades climáticas que provocam quedas de produção e da falta de uma política agrícola estável.

Com relação aos problemas climáticos, deficiências ou excessos hídricos e baixas temperaturas em períodos críticos, provocam maiores danos associados com surgimento de enfermidades (MOTA, 1982).

A produtividade da cultura está intimamente relacionada com a nutrição adequada das plantas. O rendimento da cultura depende da interrelação de 
vários fatores, e entre eles está a nutrição mineral, que requer mais estudos. Na nutrição, os micronutrientes têm importância relevante, já que são menos estudados que os macronutrientes; entretanto, do ponto de vista qualitativo estes têm a mesma importância que aqueles.

Com relação à disponibilidade de boro e zinco, o $\mathrm{pH}$ parece ser um dos fatores preponderantes, sendo considerado, por muito tempo, o único fator a afetar a disponibilidade de boro. Para o zinco, o pH exerce também efeito marcante.

O uso crescente de calcário e adubos fosfatados têm contribuído para a maior insolubilização do zinco no solo, tornando-o não disponível para as plantas, causando assim deficiência do elemento.

A recomendação de micronutrientes para as culturas é crítica, considerando que as plantas necessitam de poucas quantidades e existe uma complexidade no comportamento químico de muitos deles no solo. É essencial determinar a disponibilidade do nutriente no solo para que se faça uma recomendação adequada, evitando-se a toxidez.

Partindo-se da hipótese que a produção de massa seca e absorção de nutrientes pela planta podem variar em cada cultivar e com tipos de solos, entende-se que maior conhecimento sobre esses assuntos facilitariam a recomendação de cultivares e doses de nutrientes em função da exigência dessas e o tipo de solo.

Visando avaliar o suprimento de boro e zinco, no solo e na planta, realizaram-se experimentos em casa de vegetação com dois tipos de solo (Latossolo Roxo distrófico e Latossolo Vermelho-Escuro distrófico) e em câmara de crescimento, utilizando-se quatorze cultivares de trigo recomendadas para o Mato Grosso do Sul, avaliando-se níveis de cada nutriente (B e $\mathrm{Zn}$ ). 


\section{REVISÃO DE LITERATURA}

\subsection{Solo}

\subsubsection{Concentração e nível crítico de boro no solo}

O conteúdo total de boro (B) no solo apresenta uma variação muito grande em função do material de origem, da região e tipo de clima onde se formaram os solos. No solo, é considerado o elemento de maior mobilidade entre os micronutrientes e, em geral, a maior concentração desse elemento ocorre nos horizontes mais superficiais, porque a sua ocorrência está intimamente relacionada com o teor de matéria orgânica total, humus e teor de argila. $\mathrm{O}$ conteúdo de boro varia também em relação à textura e ao $\mathrm{pH}$. Os solos arenosos geralmente apresentam teores menores desse elemento do que os argilosos (SIMS \& BINGHAM, 1967; KEREN et alii, 1985).

AUBERT \& PINTA (1977) citaram que os teores totais de B no solo variam de 1 a $270 \mathrm{ppm}$ e que os valores médios encontram-se entre 20 a $50 \mathrm{ppm}$. Segundo os mesmos autores o B solúvel em água representa de 1 a $3 \%$ do total e o teor disponivel para as plantas varia de 0,1 a 2 ppm. Para FLEMING (1980), os teores totais de boro no solo estão entre 4 a 98 ppm e o boro disponível para as plantas entre 0,28 a $2,0 \mathrm{ppm}$.

No estado de São Paulo, BRASIL SOBRINHO (1965), estudando sete grandes grupos de solos, encontrou o seguinte: horizonte A com 31,3 a 54,0 ppm, horizonte B com 31,2 a 67,5 ppm e horizonte C com 18,7 a 56,0 ppm. Nesse mesmo Estado, CASAGRANDE (1978) encontrou os valores de 9,8 e 34,2 ppm de B total. 
MALAVOLTA (1986 e 1987) citou que os teores de boro, extraídos com água quente, encontrados nos solos brasileiros estão entre 0,1 e 3,0 ppm, sendo que a faixa considerada como adequada varia de 0,3 a $1,0 \mathrm{ppm}$ de $\mathrm{B}$, subdividida da seguinte maneira: concentrações abaixo de $0,10 \mathrm{ppm}$ é considerada baixa; de 0,10 a $0,30 \mathrm{ppm}$ como média e acima de $0,30 \mathrm{ppm}$ como adequada.

O método de extração de boro do solo mais usado é o da água quente. Usando este método, BRADFORD (1966) e COX \& KAMPRATH (1972) determinaram níveis críticos de boro, para diversas culturas, variando entre 0,1 e 0,7 ppm de boro. CARTWRIGHT et alii (1983), utilizando a cultura do trigo em dezoito tipos de solos, mencionaram também $0,7 \mathrm{ppm}$ de boro no solo como sendo o nível crítico. LOPEZ RITAS \& LOPEZ MELIDA (1978) consideraram adequados teores entre 1,0 e 5,0 ppm de boro, para a maioria das culturas, podendo haver toxidez quando os teores estiverem acima de 5,0 ppm.

\subsubsection{Concentração e nível crítico de zinco no solo}

O zinco total e o disponível para as plantas acumulam-se nas camadas superficiais do solo e estão intimamente relacionados com o humus e a matéria orgânica. A concentração de zinco também varia com relação à textura do solo, condições de oxido-redução, pH e manejo do solo.

A solubilidade e disponibilidade de zinco tem correlação negativa com saturação de cálcio e compostos de fósforo presentes no solo. Essa relação reflete nos processos de adsorção e precipitação, bem como as interações entre esses elementos. 
A concentração de zinco no solo varia de traços a 900 ppm, sendo que a média está entre 50 a 100 ppm (AUBERT \& PINTA, 1977). Segundo KABATAPENDIAS \& PENDIAS (1985a) esta concentração varia de 17 a 125 ppm, enquanto que para LINDSAY (1972) e KNEZEK \& ELLIS (1980) a concentração de zinco no solo varia de 10 a $300 \mathrm{ppm}$.

O zinco interage com a matéria orgânica formando complexos orgânicos solúveis e insolúveis. Nos solos, $60 \%$ do zinco solúvel ocorre na forma de complexos orgânicos solúveis (HODGSON et alii, 1966). Esses mesmos autores encontraram no solo os seguintes niveis de zinco: $3 \times 10^{-8}$ e $3 \times 10^{-6} \mathrm{M}$.

BROWN et alii (1971), trabalhando com 92 solos da Califórnia e usando quatro extratores para zinco (DTPA-ácido dietileno-triamino-pentacético, ditizona, $\mathrm{HCl}$ 0,1 $\mathrm{N}$ e Na2EDTA-sal dissódico do ácido etileno-diamino-tetratécito) verificaram que o DTPA foi o que apresentou melhores resultados e o nível crítico foi de 0,5 ppm usando o milho como cultura teste.

COX \& KAMPRATH (1972) citaram que o nível crítico para zinco varia conforme o extrator, sendo de 0,5 a 1,0 ppm quando se usa o DTPA a pH 7,3;1,4 a 3,0 ppm para EDTA $+\left(\mathrm{NH}_{4}\right)_{2} \mathrm{CO}_{3} ; 0,3$ a 2,3 ppm para ditizona $+\mathrm{NH}_{4} \mathrm{C}_{2} \mathrm{H}_{3} \mathrm{O}_{2}$ e 1,0 a 7,54 ppm para $\mathrm{HCl} 0,1 \mathrm{~N}$.

LINDSAY \& NORVELL (1978), utilizando o EDTA, verificaram que o nível crítico de zinco, em 42 solos, foi de $0,8 \mathrm{ppm}$ com a cultura do milho e de 0,6 ppm, em 35 solos, com a cultura do sorgo.

SINGH et alii (1980), trabalhando com 30 solos e a cultura do trigo, determinaram o nível crítico de zinco no solo de $0,65 \mathrm{ppm}$. 
No Estado do Colorado (EUA), VIETS JUNIOR \& LINDSAY (1983) estabeleceram os seguintes níveis para o zinco: abaixo de $0,5 \mathrm{ppm}$ deficientes, de 0,5 a 1,0 ppm baixo e acima de 1,0 ppm adequado.

Em São Paulo, VALADARES \& CATANI (1974), usando análises de quatorze unidades de solos, encontraram os seguintes níveis: solos derivados de rochas básicas (Litossolo - fase substrato basalto, Terra Roxa Estruturada, Latossolo Roxo eutrófico e Latossolo Roxo distrófico) de 89 a 236 ppm; de materiais aluviais e coluviais (hidromófico), de 77 a 97 ppm; de sedimentos modernos (Latossolo Vermelho-Escuro, Latossolo Vermelho-Amarelo orto, Latossolo Vermelho-Amarelo húmico e Podzólico Vermelho-Amarelo orto), de 26 a 94 ppm; do arenito Bauru (Podzolizados de Lins e Marília), de 16 a 26 ppm e de sedimentos modernos arenosos (Latossolo VermelhoAmarelo fase arenosa, Latossolo Vermelho-Escuro fase arenosa e Regossolo), de 4 a 14 ppm.

Segundo MALAVOLTA (1986 e 1987) os teores de zinco encontrados nos solos brasileiros estão entre 0,2 e 4,0 ppm. Mencionou também que concentrações abaixo de 0,5 ppm são consideradas baixas; de 0,5 a 1,0 ppm como médias e acima de 1,0 ppm como adequadas. Essas concentrações também foram determinadas por LOPEZ RITAS \& LOPES MELIDA (1978), CAMARGO et alii (1982) e BANSAL et alii (1990).

FERREIRA \& CRUZ (1992), estudando métodos para a avaliação da disponibilidade de zinco, utilizando diversos tipos de solo de São Paulo, concluíram que os extratores DTPA $0,005 \mathrm{M}$ pH 7,3 e $\mathrm{Na}^{2}$ - EDTA $1 \%$ foram os mais eficientes considerando-se os aspectos relacionados à simplicidade de manuseio e precisão. 


\subsection{Planta}

\subsubsection{Boro}

A função do boro na planta está relacionada com a formação da parede celular, divisão celular, tamanho da célula, metabolismo e transporte de carboidratos e síntese de fitohormônios.

Os sintomas de deficiência evidenciam-se pela deformação das folhas, as quais tornam-se espessas e quebradiças, pela ruptura nos pecíolos e caules, degeneração dos tecidos meristemáticos e crescimento terminal reduzido com formação de brotação lateral. Nos frutos, tubérculos e raízes a deficiência desse nutriente resulta em necrose, secamento e podridão, enquanto que no trigo ocorre a formação de espigas, porém o florescimento é reduzido.

Os sintomas de toxicidade aparecem nas pontas das folhas mais velhas, em tonalidade caramelo, evoluindo para pontuações azul-esverdeadas e finalmente secando (GUPTA, 1979).

O boro é um elemento relativamente imóvel nas plantas, acumulandose principalmente nas pontas e margens das folhas mais velhas, as quais normalmente possuem concentração mais elevada de boro que as raízes.

Existem diversos trabalhos relacionando teores do elemento na planta $\mathrm{e}$ produção (MELSTED et alii, 1969; GUPTA et alii, 1976; YADAV \& MANCHANDA, 1979; MITRA \& JANA, 1991 e PAUL et alii, 1991). Alguns desses trabalhos referem-se ao nível crítico, outros ao nível ótimo, porém GUPTA (1979) preferiu o termo suficiência. De acordo com esse autor, para certos elementos, o limite entre deficiência e suficiência é muito próximo e determinado valor considerado como crítico em alguns trabalhos pode não ser crítico em outros em condições semelhantes. 
A concentração de boro nas plantas normalmente desenvolvidas varia muito com relação às espécies, partes da planta e tipos de solo. Normalmente, as plantas dicotiledôneas possuem teores mais elevados desse elemento do que as monocotiledôneas.

SILVA \& ANDRADE (1983) e GALRÃO \& SOUZA (1988) verificaram efeito positivo da aplicação de boro na cultura do trigo, na redução da esterilidade masculina e no aumento da produção de grãos. Nesses trabalhos os autores observaram também que a ocorrência de altas temperaturas e baixas umidades relativas do ar, na fase do espigamento do trigo, foram responsáveis pela esterilidade masculina e baixas produções de grãos.

KABATA-PENDIAS \& PENDIAS (1985b) sugeriram como nível suficiente teores entre 10 a $200 \mathrm{ppm}$ para a maioria das plantas, e excessivos ou tóxicos teores entre 50 a 200 ppm. Para o trigo, GUPTA (1979) citou os níveis de 4,6 a 6,0 ppm como deficiente, $17 \mathrm{ppm}$ suficiente e acima de $34 \mathrm{ppm}$ tóxico, avaliados na palha da cultura. MALAVOLTA et alii (1989) citaram como nível adequado 20 ppm.

\subsubsection{Zinco}

A função do zinco nas plantas está associada com a respiração, controle hormonal e síntese de proteínas. O zinco é essencial para a síntese do triptofano, precursor do ácido indolacético (AIA), que é um dos responsáveis pelo aumento do volume celular. O zinco é constituinte das seguintes enzimas: anidrase carbônica, desidrogenase láctica, desidrogenase alcoólica, desidrogenase glutâmica, carboxilase pirúvica, sintetase do triptofano e ribonuclease. 
Os sintomas de deficiência desse micronutriente são caracterizados pela ocorrência de folhas pequenas, devido à impossibilidade dos tecidos crescerem normalmente. A falta de elongação dos internódios faz com que as folhas localizadas em nós sucessivos se disponham cada vez mais próximas dando o aspecto de roseta. Em algumas espécies as folhas se tornam cloróticas, enquanto que em outras podem ser verde-escuras ou azul-esverdeadas. As folhas podem ficar deformadas e necróticas.

KNEZEK \& ELLIS (1980) e KABATA-PENDIAS \& PENDIAS (1985a) citaram que os teores de zinco nos tecidos das folhas maduras podem ser subdivididos em: deficientes, de 10 a 20 ppm; normal, de 25 a 150 ppm e tóxico, de 100 a 400 ppm. Para MALAVOLTA et alii (1989) os teores de zinco na folha, considerados como adequados para a maioria das plantas, estão entre 20 e 40 ppm.

O nível crítico ou adequado de zinco no trigo varia, entre outros fatores, da parte da planta analisada e da época de amostragem. MELSTED et alii (1969), em trabalhos desenvolvidos em Illinois (EUA) determinaram como nível crítico 15 ppm de $\mathrm{Zn}$, considerando a planta inteira no estádio 10 da escala de Feeks-Large.

SINGH et alii (1980), trabalhando com 30 solos e analisando a parte aérea da planta, consideraram como nível crítico $24,5 \mathrm{ppm}$ de $\mathrm{Zn}$. Na folha bandeira, DELL \& WILSON (1985) citam teores entre 17,4 e 25,4 ppm, enquanto que RASHID \& FOX (1992) citam 17 ppm como nível crítico. 


\subsection{Fatores que afetam a disponibilidade dos micronutrientes no solo}

\subsubsection{Boro}

As concentrações ou atividades das formas iônicas dos micronutrientes na solução do solo, que geralmente são usadas pelas plantas em solos bem drenados, são dependentes do $\mathrm{pH}$ dos solos.

$\mathrm{O} \mathrm{pH}$ foi considerado, por algum tempo, como o principal fator a influenciar na disponibilidade de boro, uma vez que à medida que aumentava $\mathrm{opH}$ diminuia a absorção de boro pelas plantas (GUPTA, 1972). Entretanto, BRASIL SOBRINHO (1965) não verificou correlação significativa entre o boro solúvel e o pH do solo, em solos pertencentes aos grandes grupos do estado de São Paulo, porém obteve correlação significativa e positiva entre esses dois parâmetros quando avaliou solos pertencentes a algumas séries do município de Piracicaba, SP.

Para o boro, a faixa ideal situa-se entre $\mathrm{pH}$ 5,0 e 6,0, sendo que a partir desse valor a sua disponibilidade para as plantas diminui (DENNIS, 1987).

Solos com textura argilosa apresentam maior teor total de boro do que os de textura arenosa, embora isto não signifique maior disponibilidade para as plantas. A quantidade e o tipo de argila também influem na capacidade de adsorção do boro (SIMS \& BINGHAM, 1967).

A relação existente entre o boro e a textura do solo pode ser atribuída ao fato de que o boro é adsorvido às partículas de argila. Quanto maior o teor de argila, menor é a atividade do $\mathrm{B}$ e a produção de massa seca responde à atividade do $\mathrm{B}$ na solução do solo e não o boro adsorvido (KEREN et alii, 1985). Por outro lado, a menor quantidade de boro em solos arenosos pode estar associada com a maior lixiviação desse 
nutriente nesses solos. Isto pode explicar também o menor teor de boro total extraído em solos arenosos.

A matéria orgânica influencia a disponibilidade de boro juntamente com seu grau de decomposição, umidade e pH do solo (FLEMTNG, 1980 e TISDALE et alii, 1985). Em solos ácidos a matéria orgânica tem maior influência do que em solos alcalinos. Nestes, o pH e cálcio disponível influenciam mais na disponibilidade de boro. Nestas condições, maiores quantidades de boro são necessárias para evitar a deficiência.

Altas concentrações de nitrogênio nítrico ou amoniacal aplicadas ao solo conduzem à redução dos teores de boro nas folhas (CAMARGO \& SILVA, 1975 e GUPTA et alii, 1976). A afinidade entre boro e nitrogênio na planta é conhecida há muito tempo e é exemplificada pelo fato de que as plantas deficientes em boro não conseguem completar a síntese das proteínas (FLEMING, 1980).

Em baixa disponibilidade de boro, o efeito do potássio é semelhante ao do cálcio. Aumentando-se o nível de potássio na solução nutritiva acentuam-se os sintomas de deficiência de boro. No entanto, em altos níveis de boro, aumentando-se os níveis de potássio acentua-se a toxicidade de boro (REEVE \& SHIVE, 1944 e FLEMING, 1980).

Condições de seca reduzem o crescimento das raízes induzindo a exploração de menor volume do solo e, conseqüentemente, provocando menor absorção do nutriente. 


\subsubsection{Zinco}

Existem diversos métodos para determinar o zinco disponível para as plantas. A proporção de zinco total que está disponível varia de acordo com o reagente usado, mas está intimamente relacionada com as características fisico-químicas e tipos de solo. Em geral, o zinco disponível varia entre 5 a $20 \%$ do zinco total (AUBERT \& PINTA, 1977).

MALAVOLTA et alii (1974) citaram que os fatores que controlam a disponibilidade de zinco são: $\mathrm{pH}$, fixação pelos minerais de argila e precipitação pelo fosfato.

Com relação ao $\mathrm{pH}$, a disponibilidade é maior em pH abaixo de 5,5 , sendo mínima na faixa entre 5,5 a 7,0, a partir da qual se verifica a formação de zincato de cálcio insolúvel.

A calagem em solos ácidos e com baixos teores de zinco reduz a disponibilidade desse nutriente. Isto é atribuído ao fato de que com o aumento do $\mathrm{pH}$ diminui a solubilidade do zinco devido à combinação com as partículas de $\mathrm{MgCO}_{3} \mathrm{e} / \mathrm{ou}$ $\mathrm{CaCO}_{3}$ (TISDALE et alii, 1985).

A adsorção de zinco pelos minerais de argila e óxidos de alumínio, ferro e magnésio é altamente dependente de $\mathrm{pH}$, uma vez que a quantidade fixada aumenta com a elevação do $\mathrm{pH}$.

$\mathrm{Na}$ fixação pelos minerais de argila o zinco pode deslocar o magnésio ocupando o seu lugar, tornando-se nesse caso de dificil aproveitamento pelas plantas.

Segundo OLSEN (1972), o mecanismo da interação fósforo x zinco não é bem conhecido, porém está relacionado a altos níveis de fósforo disponível no solo ou à aplicação desse elemento ao solo. Na precipitação pelo iônio fosfato ocorre a 
formação de fosfato de zinco insolúvel, o que provoca a diminuição da disponibilidade do elemento.

A matéria orgânica, embora sendo uma das maiores fontes de micronutrientes, pode, com o aumento do seu teor, diminuir a disponibilidade de zinco no solo. Isto ocorre porque o zinco forma complexos estáveis com determinados componentes da matéria orgânica.

Existem três tipos de reação da matéria orgânica com o zinco: a) imobilização por substâncias orgânicas com moléculas de grande peso molecular como a lignina; b) solubilização e mobilização por ácidos orgânicos de cadeias pequenas e bases; e c) complexação por substâncias orgânicas que inicialmente são solúveis e após formam sais insolúveis (TISDALE et alii, 1985).

Para ELLIS \& KNEZEK (1972) o zinco é facilmente adsorvido pelos ácidos húmicos e fúlvicos da matéria orgânica.

Nitrogênio e enxofre também interferem na adsorção de zinco. A presença de $\mathrm{SO}_{4}{ }^{2-}$ favorece a solubilidade e mobilidade do $\mathrm{Zn}^{2+}$ no solo devido à formação do composto $\mathrm{ZnSO}_{4}$. A aplicação de fertilizantes nitrogenados estimula o crescimento e desenvolvimento das culturas, provocando com isto maior demanda de zinco. A quantidade e natureza das fontes nitrogenadas também influem na disponibilidade do zinco. Fertilizantes nitrogenados de características ácidas aumentam a extração do zinco, enquanto que os de natureza neutra ou básicas diminuem a extração.

A lixiviação de zinco é um problema que está relacionado com a matéria orgânica, argila e cálcio no solo. Segundo HOROWITZ \& DANTAS (1976), a lixiviação é tanto menor quanto maior for o teor de matéria orgânica e que ao longo do perfil a adsorção de zinco é função do teor de argila. 
Solos arenosos, com baixa CTC e sujeitos a chuvas intensas podem resultar em problemas de deficiência de zinco nas plantas.

O cálcio também diminui a lixiviação de zinco, pois promove a sua fixação.

\subsection{Exigências climáticas para a cultura do trigo}

Cultivares de trigo adaptadas desenvolvem-se desde o Equador até $60^{\circ}$

de latitude As regiões mais produtoras, desse cereal, no mundo estão concentradas entre 30 e $55^{\circ}$ de latitude em ambos os hemisférios, em climas moderadamente secos e moderadamente úmidos, temperados. O clima favorável para o trigo é descrito como tendo invernos suaves, verões quentes com alta radiação solar, sem chuvas intensas, com suprimento de água fornecido principalmente pela umidade armazenada no solo (MOTA, 1982).

Existem diversos trabalhos relacionando o efeito da temperatura com a taxa e o período de enchimento dos grãos, influindo, conseqüentemente, na massa final dos grãos (SPIERTZ, 1974; SOFIELD et alii, 1977; CHOWDHURY \& WARDLAW, 1978; WIEGAND \& CUELLAR, 1981 e HUNT et alii, 1991).

De um modo geral é aceito $5^{\circ} \mathrm{C}$ como temperatura mínima e $2^{\circ} \mathrm{C}$ como ótimo para o desenvolvimento do trigo. A temperatura ótima para o desenvolvimento das folhas está entre 20 e $25^{\circ} \mathrm{C}$ e para o perfilhamento entre 15 e $20^{\circ} \mathrm{C}$. A redução do crescimento em temperaturas mais elevadas é explicada pela maior perda respiratória, especialmente durante a noite, sendo a relação fotossíntese/respiração inversamente proporcional à temperatura. 
O período da floração à maturação é relativamente constante para uma cultivar em determinado ambiente, mas varia muito quando as condições ambientais são modificadas. Os fatores que favorecem o encurtamento desse período são o aumento de temperatura, grande insolação e baixa umidade do solo.

Durante o espigamento e a floração o trigo é mais suscetivel aos danos por temperaturas excessivamente altas ou baixas, o que pode levar à esterilidade e redução na formação de grãos. Neste período a temperatura ótima está entre 18 a $24^{\circ} \mathrm{C}$, com mínima de $10^{\circ} \mathrm{C}$ e máxima de $32^{\circ} \mathrm{C}$.

CAMPBELL \& DAVIDSON (1979), em experimento com trigo, concluíram que a temperatura foi o fator mais importante a influenciar o número de espiguetas por espiga, o peso das espigas e o teor de proteína no grão.

O efeito da temperatura foi estudado por ASANA \& WILLIAMS (1965), em cinco cultivares de trigo, desenvolvidas sob as seguintes temperaturas diurnas $25^{\circ}, 28^{\circ}$ e $31^{\circ} \mathrm{C}$ e noturnas de $9^{\circ}$ e $12^{\circ} \mathrm{C}$. O aumento das temperaturas diurnas causou diminuição de $16 \%$ na produção e no peso de grãos, não havendo, porém, diferença entre cultivares. Nas temperaturas noturnas não houve efeito significativo no peso dos grãos, mas o dos colmos foi menor na temperatura de $12^{\circ} \mathrm{C}$. Em outro experimento os mesmos autores.avaliaram o comportamento de seis cultivares de trigo nas temperaturas diurnas/noturnas de $24 / 19^{\circ}, 27 / 22^{\circ}$ e $30 / 25^{\circ}$ C. Duas cultivares não mostraram resposta significativa às mudanças de temperaturas diurnas-noturnas de $24 / 190$ para $27 / 22^{\circ} \mathrm{C}$, no entanto, todas foram afetadas pelas temperaturas de $30 / 25^{\circ} \mathrm{C}$.

SOFIELD et alii (1977) avaliaram a influência da temperatura em quatro cultivares de trigo e concluíram que o maior efeito ocorreu no tempo de enchimento do grão. Aumento de temperatura diurna-noturna de $21 / 16^{\circ} \mathrm{C}$ para $30 / 25^{\circ} \mathrm{C}$ reduziu o tempo de enchimento e o tamanho dos grãos. A maior taxa de crescimento do 
peso de grãos favorecida pela temperatura de $30 / 25^{\circ} \mathrm{C}$, comparada com a de $21 / 16^{\circ} \mathrm{C}$, tende a ser compensada pela redução no número de grãos. Após o florescimento, aumentando-se a temperatura ocorre diminuição do número de grãos por espiga. 


\section{MATERIAL E MÉTODOS}

Os experimentos foram conduzidos em casa de vegetação e câmara de crescimento, da Área de Nutrição Mineral de Plantas, do Departamento de Química da Escola Superior de Agricultura "Luiz de Queiroz", em Piracicaba.

\subsection{Experimentos em casa de vegetação}

Foram utilizados dois solos (Latossolo Roxo distrófico (LRd), textura argilosa e Latossolo Vermelho-Escuro distrófico (LEd), textura média), que representam aproximadamente 11 e $23 \%$, respectivamente, da área do Mato Grosso do Sul (MATO GROSSO DO SUL, 1992).

As amostras desses solos foram coletadas à profundidade de $0,20 \mathrm{~m}$, secas ao ar, homogeneizadas e peneiradas.

As determinações de macronutrientes, matéria orgânica, $\mathrm{pH}$, acidez potencial e cálculos da soma de bases, da capacidade de troca de cátions e da porcentagem de saturação por bases foram realizados segundo RAIJ \& QUAGGIO (1983). Os micronutrientes $\mathrm{Cu}, \mathrm{Fe}, \mathrm{Mn}$ e $\mathrm{Zn}$, extraídos com DTPA-TEA conforme CAMARGO et alii (1986), e B pela água quente segundo BATAGLIA \& RAIJ (1990) estão apresentados na Tabela 1 . 
Tabela 1. Resultados das análises de terra das duas amostras de solos utilizadas nos experimentos.

\begin{tabular}{|c|c|c|c|}
\hline \multirow{2}{*}{$\begin{array}{l}\text { Componente da } \\
\text { análise }\end{array}$} & \multicolumn{2}{|c|}{ Solo ${ }^{1}$} & \multirow{2}{*}{ Extratores } \\
\hline & LRd & LEd & \\
\hline $\mathrm{P}\left(\mu \mathrm{g} / \mathrm{cm}^{3}\right)$ & 3,9 & 5,2 & Resina \\
\hline M.O. (\%) & 3,57 & 3,65 & \\
\hline $\mathrm{pH}$ & 4,35 & 4,30 & $\mathrm{CaCl}_{2}$ \\
\hline $\mathrm{K}\left(\mathrm{meq} / 100 \mathrm{~cm}^{3}\right)$ & 0,10 & 0,12 & Resina \\
\hline $\mathrm{Ca}\left(\mathrm{meq} / 100 \mathrm{~cm}^{3}\right)$ & 1,42 & 0,61 & Resina \\
\hline $\mathrm{Mg}\left(\mathrm{meq} / 100 \mathrm{~cm}^{3}\right)$ & 0,62 & 0,32 & Resina \\
\hline $\mathrm{H}+\mathrm{Al}\left(\mathrm{meq} / 100 \mathrm{~cm}^{3}\right)$ & 7,95 & 8,39 & Tampão SMP \\
\hline $\mathrm{S}\left(\mathrm{meq} / 100 \mathrm{~cm}^{3}\right)$ & 2,1 & 1,1 & \\
\hline $\mathrm{T}\left(\mathrm{meq} / 100 \mathrm{~cm}^{3}\right)$ & 10,1 & 9,4 & \\
\hline $\mathrm{V}(\%)$ & 21,2 & 11,1 & \\
\hline $\mathrm{B}(\mathrm{ppm})$ & 0,56 & 0,29 & Água quente \\
\hline $\mathrm{Cu}(\mathrm{ppm})$ & 7,10 & 1,17 & DTPA-TEA ${ }^{2}$ \\
\hline $\mathrm{Fe}(\mathrm{ppm})$ & 4,1 & 104,0 & DTPA-TEA \\
\hline $\mathrm{Mn}(\mathrm{ppm})$ & 44,40 & 3,85 & DTPA-TEA \\
\hline $\mathrm{Zn}(\mathrm{ppm})$ & 0,50 & 0,51 & DTPA-TEA \\
\hline Areia $(\%)^{3}$ & 16 & 67 & \\
\hline Silte $(\%)^{3}$ & 14 & 05 & \\
\hline Argila $(\%)^{3}$ & 70 & 28 & \\
\hline
\end{tabular}

${ }^{1}$ Solo: LRd $=$ Latossolo Roxo distrófico.

LEd = Latossolo Vermelho-Escuro distrófico.

${ }^{2}$ Ácido dietileno-triamino-pentacético e trietanolamina.

${ }^{3}$ Método da pipeta. 
Para corrigir a acidez desses solos foi realizado um teste preliminar de incubação usando-se carbonatos de cálcio e magnésio na proporção de $4: 1$. Após os resultados deste teste chegaram-se às doses de corretivo $\left(\mathrm{CaCO}_{3}+\mathrm{MgCO}_{3}\right.$ relação 4:1) de $1742,4 \mathrm{mg} / \mathrm{dm}^{3}$ para o LRd e $1936 \mathrm{mg} / \mathrm{dm}^{3}$ para o LEd.

Os experimentos foram instalados em delineamento estatístico de blocos ao acaso com quatro repetições. Cada parcela constituiu-se de um vaso forrado com saco de plástico e contendo 31 de terra. Os tratamentos constituíram-se de cinco níveis de cada elemento, sendo para o boro $0,0,0,4 ; 0,8,1,2$ e $1,6 \mathrm{mg} \mathrm{B} / \mathrm{dm}^{3}$ de terra, na forma de $\mathrm{H}_{3} \mathrm{BO}_{3}$ e para o zinco $0,0,1,0,2,0,3,0$ e $4,0 \mathrm{mg} \mathrm{Zn} / \mathrm{dm}^{3}$ de terra, na forma de $\mathrm{ZnCl}_{2}$

A adubação com nitrogênio $\left(25 \mathrm{mg} / \mathrm{dm}^{3}\right)$, fósforo $\left(66,67 \mathrm{mg} / \mathrm{dm}^{3}\right)$, potássio $\left(50 \mathrm{mg} / \mathrm{dm}^{3}\right)$ e enxofre $\left(16,67 \mathrm{mg} / \mathrm{dm}^{3}\right)$ foi realizada utilizando-se as seguintes fontes de nutrientes: fosfato monobásico de potássio $\left(\mathrm{KH}_{2} \mathrm{PO}_{4}\right)$, fosfato monobásico de amônio $\left(\mathrm{NH}_{4} \mathrm{H}_{2} \mathrm{PO}_{4}\right)$, sulfato de amônio $\left(\left(\mathrm{NH}_{4}\right)_{2} \mathrm{SO}_{4}\right)$ e cloreto de amônio $\left(\mathrm{NH}_{4} \mathrm{Cl}\right)$. Durante o desenvolvimento da cultura foram realizadas duas adubações de cobertura com nitrogênio na dose de $10 \mathrm{mg} \mathrm{N} / \mathrm{dm}^{3}$, usando-se cloreto de amônio.

A planta usada como extrator foi o trigo, cultivar BR 18-Terena, que apresenta as seguintes características subperíodo da emergência ao espigamento, 50 dias; ciclo da emergência à maturação, 109 dias e altura de planta, $65 \mathrm{~cm}$ (EMBRAPA, 1987). Foram semeadas 20 sementes por vaso em 15.5 .93 e após a germinação realizouse desbaste, deixando-se seis plantas por vaso em 24.5 .93 .

Durante o desenvolvimento das plantas, diariamente adicionava-se água deionizada nos vasos visando mantê-los com $70 \%$ da capacidade de campo. Para isto, realizou-se um outro teste preliminar visando determinar o teor de água a ser mantido em cada vaso, utilizando-se um método que simula o princípio da capacidade de 
campo, segundo MARCOS $^{1}$ e denominado torrão separado pela frente de molhamento (TSFM). Este método consta do seguinte coloca-se aproximadamente $150 \mathrm{~g}$ de amostra de terra fina seca ao ar (T.F.S.A.) numa cápsula de alumínio e, com uma pipeta, adiciona-se $2 \mathrm{ml}$ de água. Após 10 segundos retira-se o torrão úmido (separado da terra seca pela frente de molhamento), o qual é imediatamente pesado, obtendo-se assim o peso úmido. $\mathrm{O}$ teor de água deste torrão é determinado gravimetricamente.

$\mathrm{Na}$ colheita foram avaliados: altura de planta (medida com régua a partir de $1 \mathrm{~cm}$ do nível do solo até a ponta da espiga), tamanho da espiga, número de grãos por espiga, massa dos grãos e rendimento de massa seca. Após a secagem do material, este foi moído e determinaram-se os teores de nutrientes na massa seca, segundo metodologia descrita por MALAVOLTA et alii (1989). Após a colheita realizou-se, também, amostragem de terra em cada vaso, para determinações químicas dos nutrientes.

\subsection{Experimentos em câmara de crescimento}

Nestes experimentos foram avaliadas quatorze cultivares de trigo submetidas a quatro níveis de boro e zinco.

A câmara de crescimento possui as dimensões de $3,0 \times 5,4 \mathrm{~m}$, sendo que a parte iluminada corresponde à área de $2,4 \times 3,0 \mathrm{~m}$. A iluminação é composta por uma combinação de 72 lâmpadas fluorescentes de $50 \mathrm{~W}$ e 28 lâmpadas de vapor de

1 MARCOS, Z.Z. (Escola Superior de Agricultura "Luiz de Queiroz"/USP, Piracicaba, SP). Comunicação pessoal, 1990. 
mercúrio de $250 \mathrm{~W}$. A intensidade luminosa média foi de 208 micro eïnsteins, 1,13 milivolts, $0,170969 \mathrm{cal} / \mathrm{cm}^{2} /$ minuto e 4.979 lux (FLOSS, 1992).

O ciclo de iluminação utilizado foi o de 12 horas luz e 12 horas escuro, controlado através de timer. $\mathrm{O}$ controle da temperatura foi realizado com dois condicionadores de ar, com capacidades de 17.000 e 18.000 BTUs. A umidificą̧ão do ambiente era feita por constante umedecimento do chão da câmara.

As cultivares de trigo avaliadas foram provenientes do Centro de Pesquisa Agropecuária do Oeste (CPAO), da EMBRAPA de Dourados, MS. As sementes foram colocadas para germinar em papel gerbox, umedecido com água destilada na proporção de $2,2 \mathrm{ml}$ de água por grama de papel. Durante o período de germinação, que foi de quatro dias, a temperatura do germinador foi mantida a $20^{\circ} \mathrm{C}$. Após este período as plântulas foram transferidas para caixas com solução nutritiva arejada constantemente e os níveis dos elementos estudados foram aplicados 24 horas após.

A sustentação das plântulas sobre a solução nutritiva foi através de orificios em chapas de PVC opaco medindo $22 \times 50 \mathrm{~cm}$ com $0,4 \mathrm{~cm}$ de espessura, instaladas em caixas de polietileno com capacidade de 151 de solução nutritiva. As chapas de sustentação tinham 128 orificios, permitindo a avaliação de quatorze cultivares por caixa, usando-se oito plântulas por subparcela, sendo seis úteis e duas como bordadura. As caixas foram pintadas externamente, com tinta alumínio, para evitar a penetração da luz.

A composição da solução nutritiva utilizada foi baseada em FURLANI \& HANNA (1984) com modificações nas concentrações de boro e zinco, Tabela 2. 
Tabela 2. Composição das soluções estoques e da solução nutritiva usadas nos experimentos.

\begin{tabular}{|c|c|c|c|c|}
\hline \multicolumn{2}{|c|}{ Solução estoque } & \multirow{2}{*}{$\begin{array}{c}\text { Estoque/ } \\
\text { solução } \\
(\mathrm{ml} / \mathrm{l})\end{array}$} & \multicolumn{2}{|c|}{ Concentração final } \\
\hline Componente & $\begin{array}{c}\text { Concentração } \\
(\mathrm{g} / 1)\end{array}$ & & Nutriente & $\mathrm{mg} / \mathrm{l}$ \\
\hline $\mathrm{Mg}\left(\mathrm{NO}_{3}\right)_{2} \cdot 6 \mathrm{H}_{2} \mathrm{O}$ & 142,4 & 0,3 & $\mathrm{~N}-\mathrm{NO}_{3}^{-}$ & 32,93 \\
\hline $\mathrm{KH}_{2} \mathrm{PO}_{4}$ & 17,6 & 0,1 & $\mathrm{~N}_{-\mathrm{NH}_{4}}^{+}$ & 4,14 \\
\hline $\mathrm{Ca}\left(\mathrm{NO}_{3}\right)_{2} \cdot 4 \mathrm{H}_{2} \mathrm{O}$ & 270,0 & 0,7 & $P$ & 0,40 \\
\hline $\mathrm{NH}_{4} \mathrm{NO}_{3}$ & 33,8 & 0,7 & $\mathrm{~K}$ & 20,01 \\
\hline $\mathrm{FeSO}_{4} 7 \mathrm{H}_{2} \mathrm{O}$ & 24,9 & 0,4 & $\mathrm{Ca}$ & 32,08 \\
\hline $\mathrm{Na}_{2} \mathrm{EDTA}$ & 29,6 & 0,4 & $\mathrm{Mg}$ & 4,05 \\
\hline $\mathrm{KCl}$ & 18,6 & 0,5 & $\mathrm{~S}$ & 4,06 \\
\hline $\mathrm{KNO}_{3}$ & 24,6 & 0,5 & $\mathrm{Cl}$ & 4,76 \\
\hline $\mathrm{K}_{2} \mathrm{SO}_{4}$ & 44,0 & 0,5 & $\mathrm{Cu}$ & 0,02 \\
\hline $\mathrm{MnCl}_{2} \cdot 4 \mathrm{H}_{2} \mathrm{O}$ & 2,34 & 0,4 & $\mathrm{Fe}$ & 0,50 \\
\hline $\mathrm{CuSO}_{4} .5 \mathrm{H}_{2} \mathrm{O}$ & 0,20 & 0,4 & $\mathrm{Mn}$ & 0,26 \\
\hline $\mathrm{MoO}_{3}$ & 0,30 & 0,1 & Mo & 0,03 \\
\hline $\mathrm{H}_{3} \mathrm{BO}_{3}$ & 2,86 & 0,1 & $\mathrm{~B}$ & - \\
\hline $\mathrm{ZnSO}_{4} \cdot \mathrm{H}_{2} \mathrm{O}$ & 1,37 & 0,1 & $\mathrm{Zn}$ & - \\
\hline
\end{tabular}


Nesses experimentos utilizou-se o delineamento estatístico de blocos ao acaso com três repetições e os tratamentos alocados de acordo com parcelas subdivididas. As parcelas foram constituídas pelos quatro niveis dos nutrientes (boro: $0,0,0,25,0,50$ e $1,25 \mathrm{mg} \mathrm{B} / \mathrm{l}$, e zinco: $0,000,0,025,0,050$ e $0,100 \mathrm{mg} \mathrm{Zn} / \mathrm{l})$ e as subparcelas pelas quatorze cultivares de trigo (Tabela 3). As plântulas permaneceram durante quinze dias na solução nutritiva. Após esse período foram coletadas separandose a parte aérea das raízes. Nesse material foram avaliados o comprimento (do colo até a ponta da folha de maior comprimento e do colo até a ponta da raiz mais comprida), massa seca, teor dos nutrientes e eficiência de utilização (EU). A eficiência de utilização de nutrientes tem sido definida como sendo a quantidade de biomassa produzida por unidade de nutriente presente nessa biomassa. Entretanto, para SIDDIQI \& GLASS (1981), em um sistema dinâmico como é solo-planta isto não representa realmente o conceito de utilização e demonstraram que o quadrado da quantidade de biomassa produzida por unidade de nutriente na biomassa é o índice que representa melhor o conceito de eficiência de utilização e este foi o modelo utilizado nos nossos experimentos.

\subsection{Análise estatística}

Os parâmetros avaliados foram submetidos à análise de variância com significância pelo teste $\mathrm{F}$ ao nível de $5 \%$ de probabilidade.

Quando a fonte de variação revelou-se significativa, realizou-se o seu

desdobramento para regressões, quando pertinentes, utilizando-se o teste $\mathrm{F}$ e $\mathrm{o}$ coeficiente de determinação para escolher a regressão que melhor se ajustasse aos dados. 
Tabela 3. Relação de cultivares de trigo usadas nos experimentos com boro e zinco em câmara de crescimento e seus respectivos ciclos.

Cultivar

Ciclo

Anahuac

intermediário

BH 1146

precoce

EMBRAPA 10-Guajá1

intermediário

Trigo BR 10-Formosa ${ }^{2}$

intermediário/tardio

Trigo BR 17-Caiuá

precoce

Trigo BR 18-Terena

intermediário

Trigo BR 20-Guató

precoce/intermediário

Trigo BR 30-Cadiuéu ${ }^{1}$

intermediário

Trigo BR 31-Miriti

intermediário

Trigo BR 36-Ianomami

precoce/intermediário

IAC 13-Lorena

precoce

IAC 18-Xavantes

precoce

IAC 24-Tucuruí

intermediário

IAPAR 6-Tapejara

precoce

IAPAR 17-Caeté

intermediário

IAPAR 28-Igapó

intermediário

${ }^{1}$ Usadas somente no experimento com zinco.

2 Usadas somente no experimento com boro. 


\section{RESULTADOS E DISCUSSÃO}

\subsection{Experimentos em casa de vegetação}

\subsubsection{Boro}

\subsubsection{No solo}

Os teores de boro determinados inicialmente nos dois tipos de solo (Latossolo Roxo distrófico e Latossolo Vermelho-Escuro distrófico) foram 0,56 e $0,29 \mathrm{mg} / \mathrm{kg}$, respectivamente. Após a correção da acidez desses solos e a aplicação do nutriente em função dos diferentes tratamentos, ocorreram modificações as quais podem ser observadas na Tabela 4.

Tabela 4. Teores de boro $(\mathrm{mg} / \mathrm{kg})$ no solo em função dos níveis de boro aplicados em dois tipos de solo (Latossolo Roxo distrófico - LRd e Latossolo VermelhoEscuro distrófico - LEd). Médias de quatro repetições.

\begin{tabular}{ccc}
\hline $\begin{array}{c}\text { Boro } \\
\mathrm{mg} / \mathrm{dm}^{3}\end{array}$ & & Solo \\
& LRd & LEd \\
\hline 0,0 & $0,54 \quad \mathrm{c}$ & $0,63 \quad \mathrm{~b}$ \\
0,4 & $0,65 \quad \mathrm{c}$ & $0,78 \mathrm{ab}$ \\
0,8 & $0,86 \quad \mathrm{~b}$ & $0,97 \mathrm{ab}$ \\
1,2 & $0,96 \mathrm{ab}$ & $1,08 \mathrm{a} \mathrm{b}$ \\
1,6 & $1,05 \mathrm{a}$ & $1,26 \mathrm{a}$ \\
\hline
\end{tabular}

Médias seguidas de mesma letra não diferem estatisticamente ao nível de $5 \%$ de significância pelo teste de Duncan. 
Pelos resultados verifica-se que as doses do nutriente proporcionaram aumentos crescentes e estatisticamente significativos nos teores de boro (Tabela 4). Os teores de boro mais elevados no LRd que no LEd detectados na análise inicial estão de acordo com SIMS \& BINGHAM (1967), os quais afirmaram que os solos de textura argilosa apresentam maior teor total de boro do que os de textura arenosa. Porém, a análise de terra após a colheita do experimento apresentou teores de boro mais elevados no LEd do que no LRd.

Os teores do nutriente determinados nos dois tipos de solos estão dentro dos limites citados por AUBERT \& PINTA (1977), FLEMING (1980) e MALAVOLTA (1986 e 1987).

A análise de regressão aplicada aos dados mostrou efeito linear para a aplicação dos níveis de boro em ambos os solos (Figura 1).

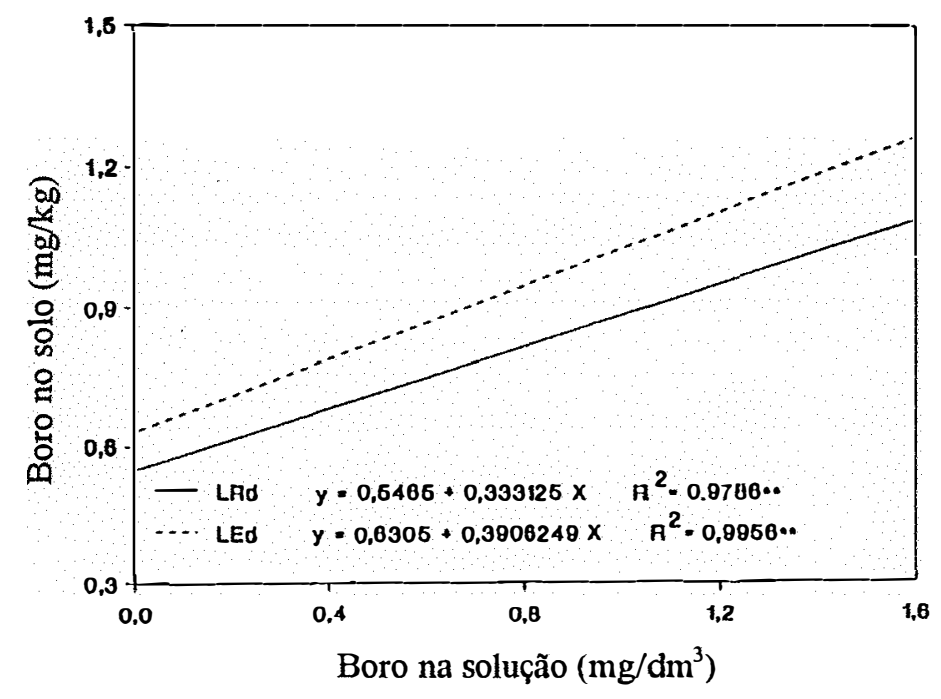

Figura 1. Teores de boro determinados em dois tipos de solo, em função da aplicação de níveis do nutriente. 


\subsubsection{Na parte aérea da planta}

Os teores médios obtidos nas determinações de boro na massa seca das plantas, na maturação plena, são apresentados na Tabela 5, e estes dados estão de acordo com os limites citados por MELSTED et alii (1969), GUPTA (1979) e MALAVOLTA et alii (1989).

Observando-se os resultados verifica-se que não houve diferença de remoção, pelas plantas, em função do tipo de solo. Isso sugere que, em ambos os solos, as quantidades de boro na solução do solo estavam prontamente disponíveis para as plantas. Percebe-se também que, com o aumento dos teores do nutriente no solo, ocorreram aumentos desse nutriente na massa seca das plantas. Isso também foi detectado por GUPTA et alii (1976) e YADAV \& MANCHANDA (1979).

A estes resultados também ajustam-se modelos lineares, conforme mostra a Figura 2.

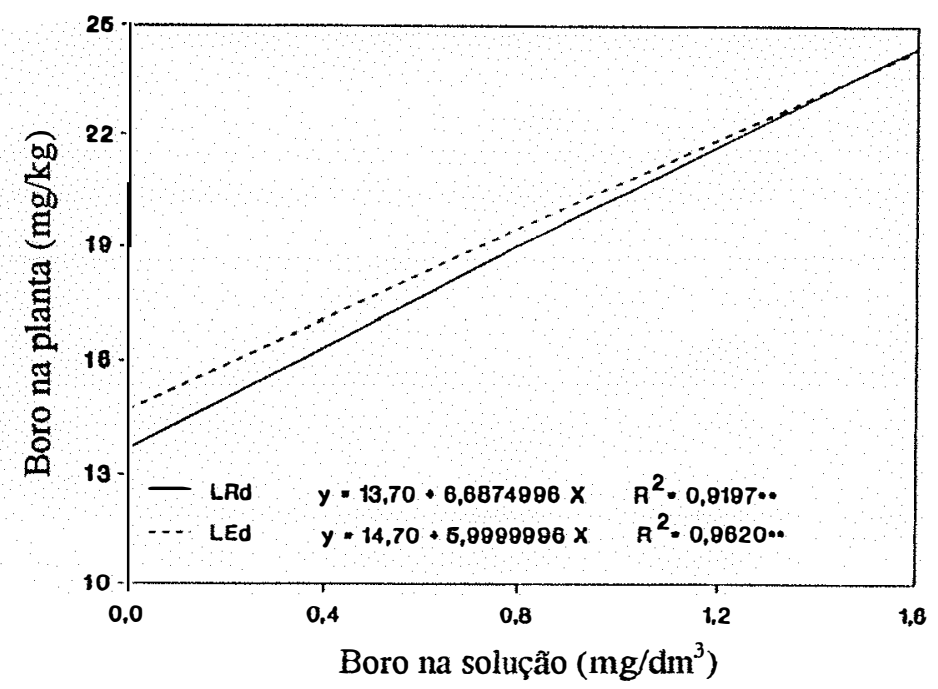

Figura 2. Teores de boro na massa seca da palha das plantas em função dos níveis aplicados aos solos. 
Tabela 5. Teores de boro ( $\mathrm{mg} / \mathrm{kg}$ ) na massa seca das plantas em função dos níveis de boro aplicados em dois tipos de solo (Latossolo Roxo distrófico - LRd e Latossolo Vermelho-Escuro distrófico - LEd). Médias de quatro repetições.

\begin{tabular}{|c|c|c|}
\hline \multirow{2}{*}{$\begin{array}{l}\text { Boro } \\
\mathrm{mg} / \mathrm{dm}^{3}\end{array}$} & \multicolumn{2}{|c|}{ Solo } \\
\hline & LRd & LEd \\
\hline 0,0 & $14 \mathrm{~b}$ & $16 \mathrm{~b}$ \\
\hline 0,4 & $16 \mathrm{ab}$ & $16 \mathrm{~b}$ \\
\hline 0,8 & $19 \mathrm{ab}$ & $10 \mathrm{ab}$ \\
\hline 1,2 & $23 \mathrm{a}$ & $21 \mathrm{a}$ \\
\hline 1,6 & $24 \mathrm{a}$ & $25 \mathrm{a}$ \\
\hline
\end{tabular}

Médias seguidas de mesma letra não diferem estatisticamente ao nível de $5 \%$ de significância pelo teste de Duncan.

\subsubsection{Componentes de produç̃̃o}

Os componentes de produção altura de planta, comprimento de espiga, número de grãos por espiga, massa dos grãos e da palha determinados no final do experimento estão apresentados na Tabela 6.

Observando-se esses resultados nota-se que, com exceção do comprimento de espiga, os demais componentes de produção apresentaram valores absolutos maiores no LEd do que no LRd, e isso deve estar associado com os teores do elemento nos solos. Conforme KEREN et alii (1985), a produção responde à atividade do boro na solução do solo e não ao adsorvido e quanto maior o teor de argila, menor é a atividade do boro. Citam também que a quantidade de boro extraída pelas plantas é maior nos solos que possuem teor de areia mais elevado. No LRd, o menor número de grãos foi compensado pelo maior peso individual dos grãos. Esse fato também foi verificado por SPIERTZ (1974) 
Tabela 6. Altura de planta, comprimento de espiga, número de grãos por espiga, massa de grãos e da palha em função dos níveis de boro nos dois tipos de solo: Latossolo Roxo distrófico - LRd e Latossolo Vermelho-Escuro distrófico LEd. Médias de quatro repetições.

\begin{tabular}{|c|c|c|c|c|c|c|c|c|c|c|}
\hline \multirow[t]{2}{*}{$\begin{array}{l}\text { Boro } \\
\mathrm{mg} / \mathrm{dm}^{3}\end{array}$} & \multicolumn{2}{|c|}{$\begin{array}{l}\text { Altura de } \\
\text { planta } \\
\text { (cm) }\end{array}$} & \multicolumn{2}{|c|}{$\begin{array}{l}\text { Comprimento } \\
\text { da espiga } \\
\text { (cm) }\end{array}$} & \multicolumn{2}{|c|}{$\begin{array}{l}\text { Número de } \\
\text { grãos/ } \\
\text { espiga }\end{array}$} & \multicolumn{2}{|c|}{$\begin{array}{l}\text { Massa dos } \\
\text { grãos } \\
\text { (g) }\end{array}$} & \multicolumn{2}{|c|}{$\begin{array}{l}\text { Massa da } \\
\text { palha } \\
\text { (g/vaso) }\end{array}$} \\
\hline & $\overline{\text { LRd }}$ & LEd & $\overline{\mathrm{LRd}}$ & LEd & LRd & LEd & $\overline{\mathrm{LRd}}$ & LEd & LRd & LEd \\
\hline 0,0 & 57,6 & 63,3 & 6,7 & 6,7 & 20 & 26 & 1,03 & 1,23 & 5,58 b & 6,62 \\
\hline 0,4 & 59,2 & 62,6 & 6,6 & 6,9 & 22 & 28 & 1,06 & 1,31 & 5,62 b & 6,98 \\
\hline 0,8 & 57,8 & 63,8 & 6,8 & 6,9 & 21 & 27 & 1,05 & 1,30 & $6,15 \mathrm{ab}$ & 6,82 \\
\hline 1,2 & 58,8 & 61,1 & 7,0 & 6,7 & 23 & 24 & 1,12 & 1,21 & $6,35 \mathrm{a}$ & 6,42 \\
\hline 1,6 & 59,5 & 62,7 & 6,9 & 7,0 & 21 & 27 & 1,09 & 1,31 & $6,07 \mathrm{ab}$ & 6,92 \\
\hline
\end{tabular}

Médias seguidas de mesma letra não diferem estatisticamente ao nível de $5 \%$ de significância pelo teste de Duncan.

Na Tabela 6 observa-se também que, somente na produção de massa seca e no LRd, houve diferença significativa para as doses de boro (Figura 3). A dose 1,2 $\mathrm{mg} \mathrm{B} / \mathrm{dm}^{3}$ foi a mais produtiva, porém não diferindo das doses 0,8 e $1,6 \mathrm{mg} \mathrm{B} / \mathrm{dm}^{3} . \mathrm{Na}$ dose zero foi onde ocorreu a menor produção de massa seca, não diferindo estatisticamente das doses 0,$4 ; 0,8$ e $1,6 \mathrm{mg} \mathrm{B} / \mathrm{dm}^{3}$. 


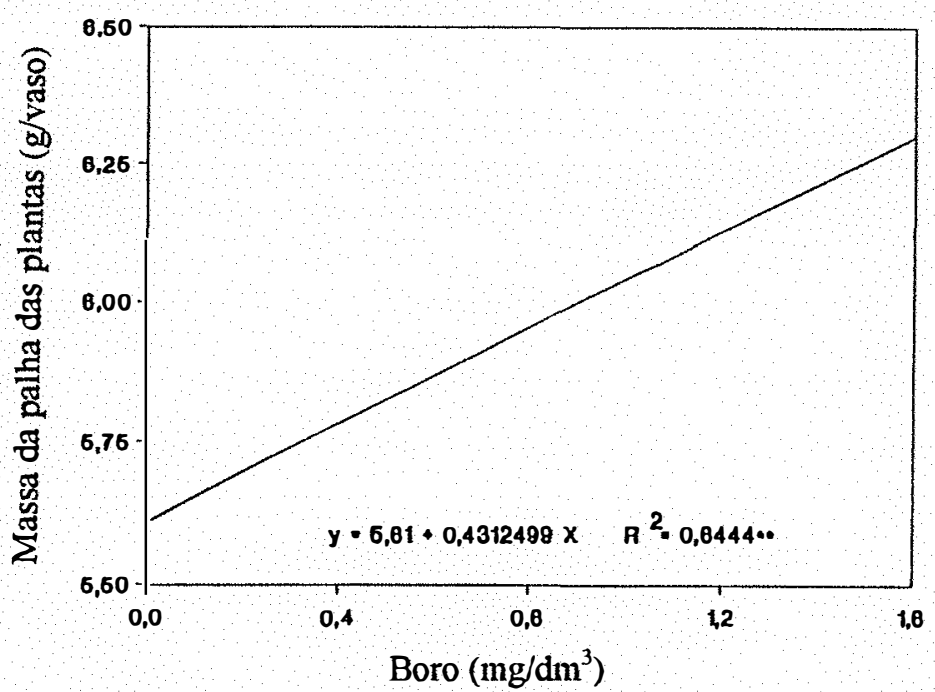

Figura 3. Efeitos dos níveis de boro aplicados ao solo na produção de massa seca da palha de trigo no Latossolo Roxo distrófico.

GUPTA et alii (1976), em seus experimentos em casa de vegetação, verificaram que a aplicação de $0,5 \mathrm{ppm}$ de boro foi suficiente para reduzir a produção de trigo. Verificaram também que aplicando $50 \mathrm{ppm}$ ou mais de nitrogênio houve decréscimo na absorção de boro e diminuição dos efeitos da toxidez. A concentração de boro nas plantas aumentou com as doses de boro mas diminuiu com o aumento das doses de nitrogênio. Plantas com mais de $16 \mathrm{ppm}$ de boro apresentaram sintomas de toxidez. Em experimentos no campo, os sintomas de toxicidade de boro nas folhas estavam associados com concentrações maiores que $11 \mathrm{ppm}$ no tecido. Ocorreram decréscimos de produção com o aumento das doses de boro associados com queima das pontas das folhas nos primeiros estádios de crescimento, mesmo os sintomas 
desaparecendo com o desenvolvimento das plantas. Nesse experimento a concentração de boro nos tecidos também aumentou com as doses aplicadas.

AHMAD et alii (1979), também trabalhando com níveis de boro na cultura do trigo, verificaram que o peso de mil grãos e a produção aumentaram até a dose de $1 \mathrm{ppm}$ de boro e depois houve decréscimo. Segundo os autores a resposta do trigo à aplicação de boro indicou que havia baixa disponibilidade do elemento no solo, entretanto sem sintomas de deficiência. A aparência das plantas tanto nas parcelas testemunhas como nas tratadas era a mesma.

\subsubsection{Zinco}

\subsubsection{No solo}

Os teores de zinco determinados na análise inicial nos dois tipos de solo (LRd e LEd) foram de 0,50 e $0,51 \mathrm{mg} / \mathrm{kg}$, respectivamente, os quais são considerados como nível crítico no solo por BROWN et alii (1971) e COX \& KAMPRATH (1972), porém, para LINDSAY \& NORVELL (1978), SINGH et alii (1980) e VIETS JUNIOR \& LINDSAY (1983) são considerados como nível baixo.

Após a correção da acidez desses solos, aplicação de zinco em diferentes níveis e extração pela cultura do trigo obtiveram-se os resultados que estão na Tabela 7. 
Tabela 7. Teores de zinco $(\mathrm{mg} / \mathrm{kg})$ no solo em função dos níveis de zinco em dois tipos de solo (Latossolo Roxo distrófico - LRd e Latossolo Vermelho-Escuro distrófico - LEd). Médias de quatro repetições.

\begin{tabular}{|c|c|c|c|c|}
\hline \multirow{2}{*}{$\begin{array}{l}\text { Zinco } \\
\mathrm{mg} / \mathrm{dm}^{3}\end{array}$} & \multicolumn{4}{|c|}{ Solo } \\
\hline & LRd & & $\mathrm{LEd}$ & \\
\hline 0,0 & 0,72 & d & 0,27 & $\mathrm{~d}$ \\
\hline 1,0 & 0,79 & d & 0,50 & $d$ \\
\hline 2,0 & 0,96 & c & 0,66 & c \\
\hline 3,0 & $1,15 \quad b$ & b & 0,84 & \\
\hline 4,0 & 1,29 a & & 1,03 & \\
\hline
\end{tabular}

Médias seguidas de mesma letra não diferem estatisticamente ao nível de $5 \%$ de significância pelo teste de Duncan.

Observa-se que em ambos os solos ocorreram aumentos significativos do nutriente em função das doses aplicadas. No LEd o teor do nutriente no nivel zero é considerado como baixo, nos níveis 1,$0 ; 2,0$ e 3,0 como médio e no nível 4,0 como adequado, enquanto que no LRd os teores estão entre os limites considerados como médios a adequados por LOPES RITAS \& LOPEZ MELIDA (1978), CAMARGO et alii (1982), MALAVOLTA (1986 e 1987) e BANSAL et alii (1990).

Verifica-se também que no LRd os teores são maiores que no LEd em todos os tratamentos e isso deve estar associado à textura do solo.

A esses resultados ajustam-se equações lineares em função dos níveis de zinco aplicados (Figura 4). 


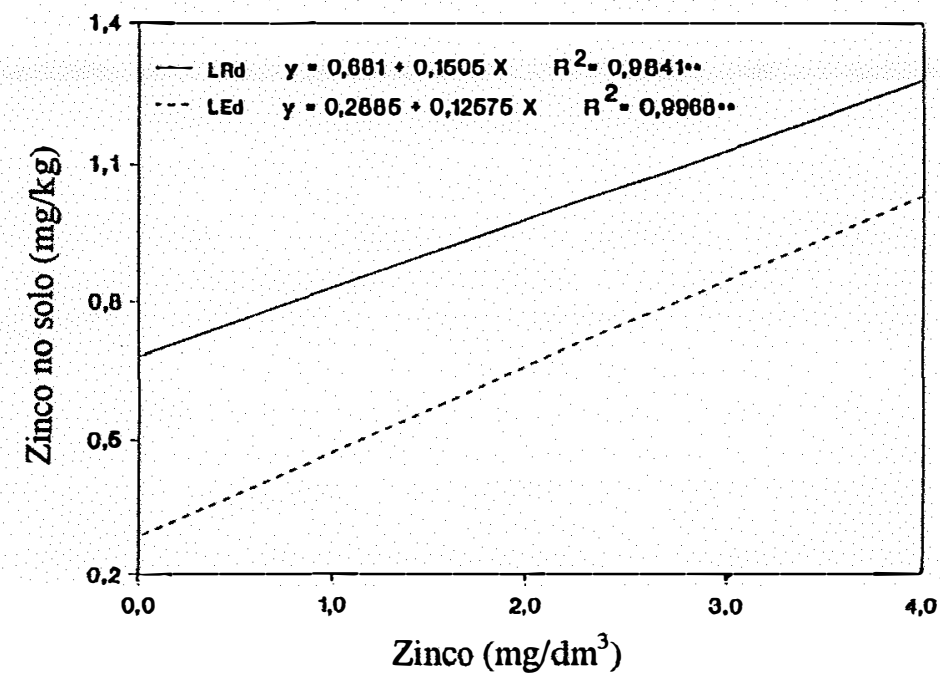

Figura 4. Teores de zinco determinados em dois tipos de solo, em função da aplicação de niveis do nutriente.

\subsubsection{Na parte aérea da planta}

Os teores médios encontrados nas determinações de zinco na massa seca das plantas, na maturação plena, apresentados na Tabela 8 , são considerados baixos segundo KNEZEK \& ELLIS (1980), SINGH et alii (1980), KABATA-PENDIAS \& PENDIAS (1985a) e MALAVOLTA et alii (1989).

Os teores nas plantas no LRd apresentam diferenças estatisticamente significativas, enquanto que no LEd isso não ocorreu. 
Tabela 8. Teores de zinco $(\mathrm{mg} / \mathrm{kg})$ na massa seca das plantas em função dos níveis de zinco aplicados em dois tipos de solo (Latossolo Roxo distrófico - LRd e Latossolo Vermelho-Escuro distrófico - LEd). Médias de quatro repetições.

\begin{tabular}{cccc}
\hline \multirow{2}{*}{$\begin{array}{c}\text { Zinco } \\
\mathrm{mg} / \mathrm{dm}^{3}\end{array}$} & \multicolumn{2}{c}{ Solo } \\
\cline { 2 - 3 } & & LRd & LEd \\
\hline 0,0 & $11 \mathrm{~b}$ & $8 \mathrm{a}$ \\
1,0 & $12 \mathrm{~b}$ & $9 \mathrm{a}$ \\
2,0 & $17 \mathrm{ab}$ & $11 \mathrm{a}$ \\
\hline 3,0 & $19 \mathrm{a}$ & $10 \mathrm{a}$ \\
4,0 & $19 \mathrm{a}$ & $11 \mathrm{a}$ \\
\hline
\end{tabular}

Médias seguidas de mesma letra não diferem estatisticamente ao nível de $5 \%$ de significância pelo teste de Duncan.

Aumentos de concentração de zinco na palha em função das doses aplicadas também foram observados por SINHA et alii, 1984 e RAJ \& GUPTA, 1986.

RASHID \& FOX (1992), trabalhando com diversas culturas e entre elas o trigo, concluíram que a concentração de $17 \mathrm{ppm}$ de $\mathrm{Zn}$ na folha bandeira está associada com $95 \%$ da produção máxima.

Os aumentos dos teores de zinco na massa seca das plantas também apresentaram efeito linear com o aumento das doses aplicadas (Figura 5). 


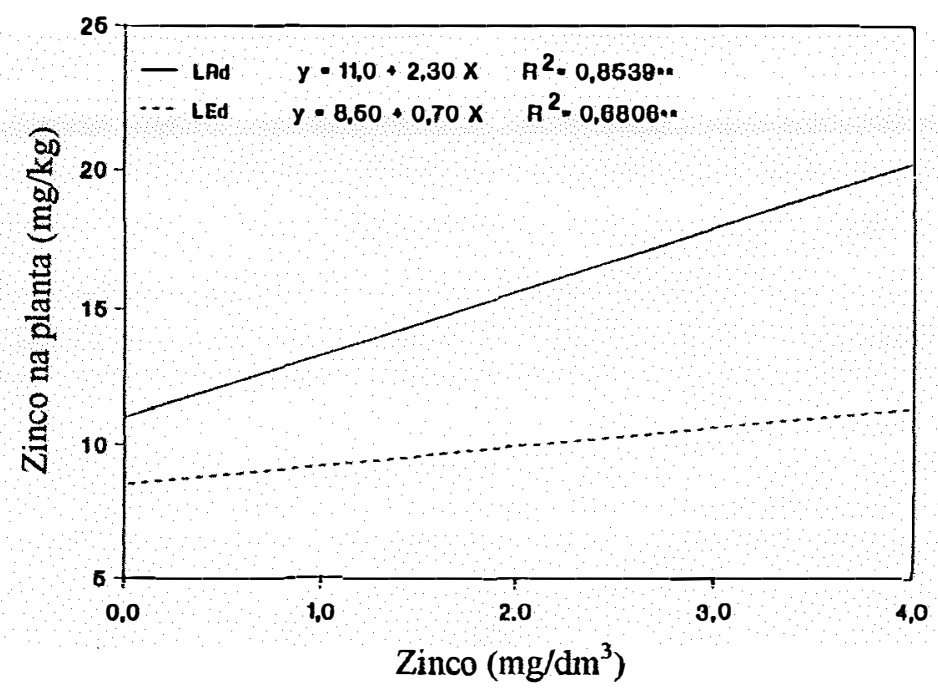

Figura 5. Teores de zinco na massa seca das plantas em função dos níveis aplicados aos solos.

\subsubsection{Componentes de produção}

Os componentes de produção altura de planta, comprimento de espiga, número de grãos por espiga, massa dos grãos e da palha determinados na época da colheita do experimento estão na Tabela 9 . A análise estatística desses resultados não apresentou diferenças para qualquer dos componentes de produção avaliados.

Observando-se os resultados da Tabela 9 verifica-se que o número de grãos, massa dos grãos e da palha foram menores no LRd do que no LEd. Com relação aos grãos, o menor número foi compensado pelo maior valor individual dos grãos. SPIERTZ (1974) observou que redução de $50 \%$ no número de grãos aumentou em $25 \%$ o peso individual dos mesmos. RAJ \& GUPTA (1986) também verificaram aumentos de concentração e extração de zinco com o aumento das doses aplicadas sem, 
no entanto, influenciar na produção. Segundo esses autores, isso indica que uma vez alcançado o mínimo exigido pela planta, pode haver acumulação do nutriente sem acarretar em aumentos de produção.

Tabela 9. Altura de planta, comprimento de espiga, número de grãos por espiga, massa de grãos e da palha em função dos diferentes níveis de zinco nos dois tipos de solo: Latossolo Roxo distrófico - LRd e Latossolo Vermelho-Escuro distrófico - LEd. Médias de quatro repetições.

\begin{tabular}{|c|c|c|c|c|c|c|c|c|c|c|}
\hline \multirow[t]{2}{*}{$\begin{array}{c}\text { Zinco } \\
\mathrm{mg} / \mathrm{dm}^{3}\end{array}$} & \multicolumn{2}{|c|}{$\begin{array}{l}\text { Altura de } \\
\text { planta } \\
\text { (cm) }\end{array}$} & \multicolumn{2}{|c|}{$\begin{array}{l}\text { Comprimento } \\
\text { da espiga } \\
\text { (cm) }\end{array}$} & \multicolumn{2}{|c|}{$\begin{array}{c}\text { Número de } \\
\text { grãos/ } \\
\text { espiga }\end{array}$} & \multicolumn{2}{|c|}{$\begin{array}{l}\text { Massa dos } \\
\text { grãos } \\
\text { (g) }\end{array}$} & \multicolumn{2}{|c|}{$\begin{array}{c}\text { Massa da } \\
\text { palha } \\
\text { (g/vaso) }\end{array}$} \\
\hline & LRd & LEd & LRd & LEd & LRd & LEd & LRd & LEd & LRd & LEd \\
\hline 0,0 & 62,0 & 61,4 & 6,9 & 6,9 & 23 & 26 & 1,13 & 1,24 & 6,35 & 6,90 \\
\hline 1,0 & 61,4 & 61,6 & 7,0 & 7,0 & 22 & 26 & 1,16 & 1,26 & 6,58 & 6,82 \\
\hline 2,0 & 62,7 & 61,9 & 6,9 & 7,0 & 24 & 24 & 1,16 & 1,21 & 6,12 & 7,18 \\
\hline 3,0 & 61,9 & 59,8 & 7,0 & 7,0 & 24 & 28 & 1,17 & 1,31 & 6,68 & 6,80 \\
\hline 4,0 & 61,6 & 61,1 & 7,2 & 7,2 & 22 & 27 & 1,04 & 1,32 & 6,55 & 7,15 \\
\hline
\end{tabular}

\subsubsection{Fatores climáticos que influem na produção}

A produção de folhas, perfilhamento e espigamento são afetados pela temperatura e intensidade luminosa. Durante o emborrachamento a temperatura tem grande influência na taxa de crescimento, enquanto que a intensidade luminosa determina o número de espigas por planta e o desenvolvimento das espiguetas.

SPIERTZ (1974), estudando o comportamento do trigo aos fatores climáticos, concluiu que a produção de grãos depende do balanço entre o suprimento de 
carboidratos e a produção de espigas. O suprimento de carboidratos é determinado pela temperatura e intensidade luminosa porque ambos afetam a taxa de assimilação e o período de duração da área foliar. A redução do número de grãos por espiga pode ser compensada parcialmente pelo aumento do peso dos grãos. A temperatura afeta a produção de espigas pela influência que tem na taxa de assimilação e acumulação de carboidratos nas mesmas. Há evidências de que a temperatura influi em vários processos, tais como taxa de translocação de assimilados, acúmulo de açúcares no grão e taxa de conversão de açúcares em amido

Durante o período de desenvolvimento dos experimentos, de 15.5 .93 a 23.8.93, foi anotada a temperatura do ar com termohigrógrafo, dentro da casa de vegetação, e os valores estão representados na Figura 6.

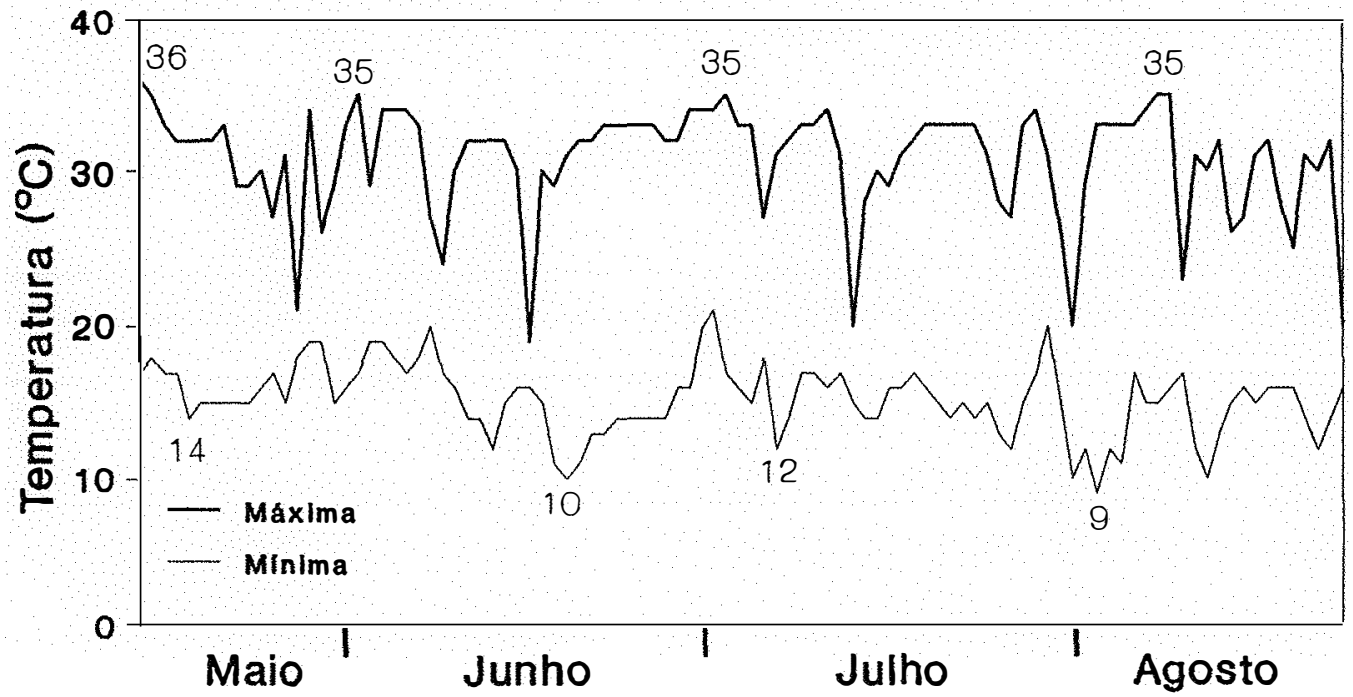

Figura 6. Temperaturas máximas e mínimas registradas no período de 15.5 .93 a 23.8.93. 
Pelos valores de temperatura apresentados na Figura 6 depreende-se que a mesma pode ter afetado o rendimento final da cultura, uma vez que essa apresentou um período de 46 dias da emergência ao espigamento e 97 dias da emergência à maturação completa, portanto menores do que os relatados por EMBRAPA (1987), os quais foram de 50 e 109 dias, respectivamente. Analisando-se a Figura 6 , verifica-se que durante 0 mês de maio as temperaturas mínimas não apresentaram problemas, uma vez que a média dessas temperaturas ficou em $16^{\circ} \mathrm{C}$, atingindo o máximo de $19^{\circ} \mathrm{C}$. Com relação às temperaturas máximas, essas apresentaram valores acima do considerado ideal para as plantas, atingindo o máximo de $36^{\circ} \mathrm{C}$ e a média do período com $31^{\circ} \mathrm{C}$. No mês de junho a média das temperaturas mínimas foi de $15^{\circ} \mathrm{C}$ com o máximo de $20^{\circ} \mathrm{C}$. A média das temperaturas máximas foi de $31^{\circ} \mathrm{C}$ e a mais alta foi de $35^{\circ} \mathrm{C}$, temperaturas consideradas altas para a cultura nesse período.

Em julho a média das mínimas ficou em $16^{\circ} \mathrm{C}$, não apresentando problemas para o trigo, no entanto, a média das temperaturas máximas ficou em $31^{\circ} \mathrm{C}$ com pico máximo de $35^{\circ} \mathrm{C}$. Nesse período as temperaturas altas foram prejudiciais à cultura porque o início do espigamento ocorreu em 3.7.93, quando a temperatura máxima estava em $34^{\circ} \mathrm{C}$, sendo que a máxima permitida para esta fase do desenvolvimento é de $32^{\circ} \mathrm{C}$. No mês de agosto as temperaturas foram mais baixas, ficando a média das mínimas em $14^{\circ} \mathrm{C}$ e a das máximas em $30^{\circ} \mathrm{C}$. As temperaturas máximas nesta fase do desenvolvimento da cultura também foram elevadas.

Há uma relação inversa entre número e tamanho de grãos. $O$ peso de grãos diminui com aumentos de temperatura acima de $18^{\circ} \mathrm{C}$ dia e $13^{\circ} \mathrm{C}$ noite (CHOWDHURY \& WARDLAW, 1978 e HUNT et alii, 1991). O peso dos grãos diminui $2,8 \mathrm{mg}$ a cada ${ }^{\circ} \mathrm{C}$ de aumento de temperatura (WIEGAND \& CUELLAR, 1981). 
Temperaturas baixas durante a maturação do grão favorecem o aumento do peso individual dos mesmos, bem como a sua formação. Por isso produções de trigo em regiões frias normalmente são maiores do que as de regiões quentes.

Aumentos de temperatura reduzem o período mas aumentam a taxa de enchimento dos grãos (SPIERTZ, 1974; CHOWDHURY \& WARDLAW, 1978 e HUNT et alii, 1991). Acréscimos de $1^{\circ} \mathrm{C}$ na temperatura diminuíram em três dias o enchimento dos grãos (WIEGAND \& CUELLAR, 1981).

SPIERTZ (1974) verificou que após o florescimento a taxa de crescimento dos grãos aumentou com a temperatura, assim como a senescência das folhas e outras partes verdes da planta. $\mathrm{O}$ resultado disso foi um rápido aumento na taxa de crescimento num período curto a $25^{\circ} \mathrm{C}$ e um crescimento lento por um período mais longo a $15^{\circ} \mathrm{C}, 18,3^{\circ} \mathrm{C}$ e $21,7^{\circ} \mathrm{C}$. $\mathrm{O}$ tempo de enchimento dos grãos foi de 52 dias a $15^{\circ} \mathrm{C}$ e de 26 dias a $25^{\circ} \mathrm{C}$. Aumentos de $10^{\circ} \mathrm{C}$ na temperatura diminuíram para a metade o tempo de enchimento dos grãos. A área foliar também diminuiu de $63 \mathrm{~cm}^{2}$ a $15^{\circ} \mathrm{C}$ para $21 \mathrm{~cm}^{2}$ a $25^{\circ} \mathrm{C}$.

O início do florescimento diferiu entre diversas cultivares, variando de 44 a 67 dias após a germinação e o período de enchimento dos grãos variou entre 28,7 a 36,4 dias em temperaturas constantes de $20^{\circ} \mathrm{C}$ dia e $15^{\circ} \mathrm{C}$ noite (HUNT et alii, 1991).

TOLLENAAR et alii (1991) também verificaram efeito da temperatura na produção de massa seca e concluíram que a maior produção ocorreu com temperaturas de $23 / 14^{\circ} \mathrm{C}$ dia/noite, comparadas com $16 / 7^{\circ} \mathrm{C}$ e $33 / 24^{\circ} \mathrm{C}$ dia e noite, respectivamente

Outro fator relevante é com relação à temperatura da espiga. PARARAJASINGHAM \& HUNT (1991) constataram que a temperatura da espiga foi 
$1,5^{\circ} \mathrm{C}$ maior que a temperatura ambiente no campo com adequado suprimento de água. Em casa de vegetação a temperatura das espigas foi 3 a $4^{\circ} \mathrm{C}$ maior que a do ambiente.

O suprimento de assimilados para o crescimento dos órgãos das plantas depende da atividade e duração da fotossíntese, principalmente nas folhas. A temperatura influencia no suprimento de assimilados de várias maneiras. Temperaturas baixas favorecem a eficiência da fotossíntese (TOLLENAAR et alii, 1991). Temperaturas altas aceleram a senescência das folhas e aumentam a respiração das folhas, colmos e espigas. Há evidências de que em altas temperaturas o movimento de nitrogênio das folhas para os grãos é grande (SPIERTZ, 1974). Isso pode ser um fator importante afetando o período de duração da área foliar.

\subsection{Experimentos em câmara de crescimento}

\subsubsection{Boro}

\subsubsection{Comprimento da parte aérea e da raiz}

As análises de variância dos resultados mostraram que os níveis de boro influíram significativamente no comprimento da parte aérea, porém o mesmo não aconteceu com o comprimento das raízes. Com relação às cultivares, as mesmas também

responderam significativamente à aplicação de boro. $\mathrm{O}$ desdobramento das interações apresentou resultados diferentes para cada cultivar. Na Tabela 10 são apresentadas as equações de regressão entre os níveis de boro e o comprimento da parte aérea e seus coeficientes de determinação. 
Tabela 10. Equações de regressão e coeficientes de determinação $\left(R^{2}\right)$ entre os níveis de boro e o comprimento da parte aérea em cultivares de trigo.

\begin{tabular}{lcc}
\hline Cultivar & \multicolumn{1}{c}{ Equação } & $\mathrm{R}^{2}$ \\
\hline BR 17-Caiuá & $\mathrm{Y}=20,8489+11,5023 \sqrt{\mathrm{X}}-6,90348 \mathrm{X}$ & $0,747^{* *}$ \\
BR 31-Miriti & $\mathrm{Y}=19,8846+19,3225 \sqrt{\mathrm{X}}-12,8996 \mathrm{X}$ & $0,735^{* *}$ \\
IAC 13-Lorena & $\mathrm{Y}=18,5614+15,217 \sqrt{\mathrm{X}}-10,3136 \mathrm{X}$ & $0,626^{*}$ \\
IAC 18-Xavantes & $\mathrm{Y}=25,1957+12,8654 \sqrt{\mathrm{X}}-7,34837 \mathrm{X}$ & $0,602^{*}$ \\
IAC 24-Tucuruí & $\mathrm{Y}=17,1468+11,6381 \sqrt{\mathrm{X}}-7,49035 \mathrm{X}$ & $0,700^{* *}$ \\
IAPAR 6-Tapejara & $\mathrm{Y}=22,2983+9,24861 \mathrm{X}-5,70165 \mathrm{X}^{2}$ & $0,513^{*}$ \\
IAPAR 17-Caeté & $\mathrm{Y}=19,5416+10,8724 \sqrt{\mathrm{X}}-6,38981 \mathrm{X}$ & $0,578^{*}$ \\
IAPAR 28-Igapó & $\mathrm{Y}=20,0475+10,4269 \sqrt{\mathrm{X}}-7,55033 \mathrm{X}$ & $0,657^{* *}$ \\
\hline
\end{tabular}

Para as cultivares Anahuac, BR 10-Formosa, BR 18-Terena, BH 1146, BR 20-Guató e BR 36-Ianomami (Tabela 11) os resultados não se ajustaram aos modelos matemáticos usados. Todas as cultivares apresentaram taxa de crescimento mais acentuado entre os níveis zero e $0,25 \mathrm{mg} \mathrm{B/1}$ (Figura 7a e b e Tabela 11).

A cultivar IAPAR 28-Igapó atingiu o máximo de tamanho da parte aérea com o nível de boro de 0,48 mg B/l. As cultivares BR 31-Miriti e IAC 13-Lorena tiveram comportamento semelhante, atingindo o máximo comprimento com os níveis de 0,56 e 0,54 mg B/l e a partir daí decresceram. No entanto, a BR 31-Miriti apresentou maior tamanho que a IAC 13-Lorena. A cultivar BR 17-Caiuá apresentou comprimento máximo com o nível de boro de $0,69 \mathrm{mg} \mathrm{B} / \mathrm{l}$. AS cultivares IAC 18-Xavantes e IAC 24Tucuruí atingiram o máximo de crescimento com os níveis de boro de 0,87 e 0,60 mg B/l. A IAC 18-Xavantes foi a cultivar que apresentou maior desenvolvimento da parte aérea entre todas as cultivares avaliadas. As cultivares IAPAR 6-Tapejara e 
IAPAR 17-Caeté apresentaram crescimento máximo com os níveis de boro de 0,81 e $0,72 \mathrm{mg} \mathrm{B} / 1$, respectivamente (Figura $7 \mathrm{a} \mathrm{e} \mathrm{b}$ ).

Tabela 11. Comprimento da parte aérea em função dos níveis de boro. Médias de quatro repetições.

\begin{tabular}{lcccc}
\hline & \multicolumn{4}{c}{ Boro (mg/l) } \\
\cline { 2 - 5 } Cultivar & 0,00 & 0,25 & 0,50 & 1,25 \\
\hline Anahuac & -12 & 25 & 25 & 25 \\
BH 1146 & 23 & 27 & 28 & 26 \\
BR 10-Formosa & 22 & 24 & 24 & 24 \\
BR 18-Terena & 23 & 26 & 24 & 25 \\
BR 20-Guató & 24 & 28 & 25 & 27 \\
BR 36-Ianomami & 24 & 26 & 23 & 25 \\
\end{tabular}




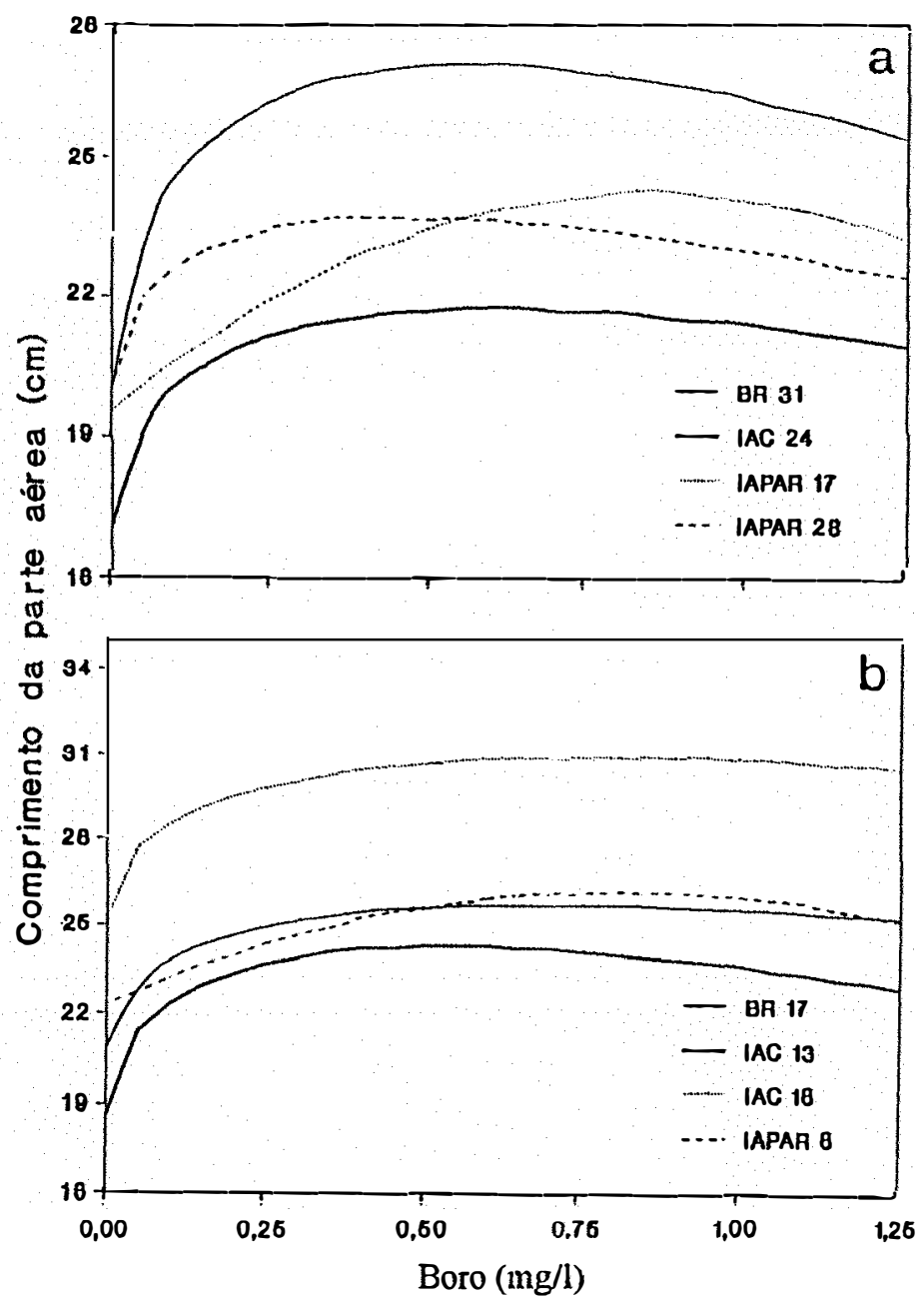

Figura 7. Comprimento da parte aérea $(\mathrm{cm})$, em função dos níveis de boro.

Com relação às raízes, embora a análise de variância tenha indicado interação significativa entre os níveis de boro e cultivares, os resultados não se ajustaram aos modelos matemáticos avaliados. $\mathrm{Na}$ Tabela 12 estão os valores relativos ao comprimento das raízes em função dos níveis de boro avaliados e pela análise desses resultados verifica-se que todas as variedades apresentaram maior desenvolvimento das raízes com o nível 1,25 mg B/l. No entanto, para $\mathrm{BH} 1146$, IAC 13-Lorena, IAC 24- 
Tucuruí e IAPAR 28-Igapó, o comprimento das raízes com 0,25 mg B/l foi estatisticamente igual ao nível máximo.

Tabela 12. Comprimento das raízes $(\mathrm{cm})$ das cultivares em função dos níveis de boro. Médias de três repetições.

\begin{tabular}{lllll}
\hline & \multicolumn{4}{c}{ Boro (mg/l) } \\
\cline { 2 - 4 } Cultivar & 0,00 & 0,25 & 0,50 & 1,25 \\
\hline Anahuac & $43 \mathrm{c}$ & $51 \mathrm{~b}$ & $46 \mathrm{bc}$ & $60 \mathrm{a}$ \\
BH 1146 & $58 \mathrm{~b}$ & $65 \mathrm{a}$ & $58 \mathrm{~b}$ & $70 \mathrm{a}$ \\
BR 10-Formosa & $48 \mathrm{bc}$ & $50 \mathrm{~b}$ & $44 \mathrm{c}$ & $62 \mathrm{a}$ \\
BR 17-Caiuá & $57 \mathrm{~b}$ & $57 \mathrm{~b}$ & $49 \mathrm{c}$ & $64 \mathrm{a}$ \\
BR 18-Terena & $41 \mathrm{c}$ & $49 \mathrm{~b}$ & $41 \mathrm{c}$ & $58 \mathrm{a}$ \\
BR 20-Guató & $58 \mathrm{c}$ & $64 \mathrm{~b}$ & $61 \mathrm{bc}$ & $70 \mathrm{a}$ \\
BR 31-Miriti & $58 \mathrm{~b}$ & $63 \mathrm{~b}$ & $58 \mathrm{~b}$ & $71 \mathrm{a}$ \\
BR 36-Ianomami & $43 \mathrm{~d}$ & $55 \mathrm{~b}$ & $48 \mathrm{c}$ & $69 \mathrm{a}$ \\
IAC 13-Lorena & $53 \mathrm{~b}$ & $58 \mathrm{ab}$ & $54 \mathrm{a}$ & $63 \mathrm{a}$ \\
IAC 18-Xavantes & $59 \mathrm{~b}$ & $63 \mathrm{~b}$ & $59 \mathrm{~b}$ & $73 \mathrm{a}$ \\
IAC 24-Tucuruí & $51 \mathrm{c}$ & $57 \mathrm{ab}$ & $54 \mathrm{bc}$ & $61 \mathrm{a}$ \\
IAPAR 6-Tapejara & $59 \mathrm{~b}$ & $62 \mathrm{~b}$ & $64 \mathrm{ab}$ & $69 \mathrm{a}$ \\
IAPAR 17-Caeté & $52 \mathrm{~b}$ & $56 \mathrm{~b}$ & $52 \mathrm{~b}$ & $65 \mathrm{a}$ \\
IAPAR 28-Igapó & $51 \mathrm{~b}$ & $58 \mathrm{a}$ & $57 \mathrm{a}$ & $62 \mathrm{a}$ \\
\hline
\end{tabular}

Médias seguidas de mesma letra, na horizontal, não diferem pelo teste de Duncan ao nível de $5 \%$ de significância.

\subsubsection{Teor de boro na parte aérea e nas raízes}

As análises de variância dos resultados mostraram que os níveis de boro aplicados influíram nos teores desse elemento na parte aérea das plantas e as cultivares responderam de modo diferente a esses níveis. PAUL et alii também 
obtiveram aumentos de concentração de boro na parte aérea do trigo em função dos niveis de boro aplicados. Com relação às raizes, as cultivares não responderam aos niveis de boro aplicados. Na Tabela 13 estão as equações de regressão entre os niveis de boro e o teor do nutriente na parte aérea das plantas.

Tabela 13. Equações de regressão e coeficientes de determinação $\left(\mathrm{R}^{2}\right)$ entre niveis de boro e o teor do nutriente na parte aérea das plantas.

\begin{tabular}{llc}
\hline Cultivar & \multicolumn{1}{c}{ Equação } & $\mathrm{R}^{2}$ \\
\hline Anahuac & $\mathrm{Y}=52,2983+43,2488 \mathrm{X}+60,9650 \mathrm{X}^{2}$ & $0,902^{* *}$ \\
BH 1146 & $\mathrm{Y}=41,869+118,762 \mathrm{X}$ & $0,819^{* *}$ \\
BR 10-Formosa & $\mathrm{Y}=102,528-195,281 \mathrm{X}+236,862 \mathrm{X}^{2}$ & $0,938^{* *}$ \\
BR 17-Caiuá & $\mathrm{Y}=46,4143-2,15459 \mathrm{X}+60,0810 \mathrm{X}^{2}$ & $0,861^{* *}$ \\
BR 18-Terena & $\mathrm{Y}=24,6823+184,288 \sqrt{\mathrm{X}}-63,6126 \mathrm{X}$ & $0,811^{* *}$ \\
BR 20-Guató & $\mathrm{Y}=33,4524+108,095 \mathrm{X}$ & $0,862^{* *}$ \\
BR 31-Miriti & $\mathrm{Y}=28,2738+96,2857 \mathrm{X}$ & $0,939^{* *}$ \\
BR 36-Ianomami & $\mathrm{Y}=80,5469-28,0439 \mathrm{X}+92,2135 \mathrm{X}^{2}$ & $0,779^{* *}$ \\
IAC 13-Lorena & $\mathrm{Y}=26,2976+99,2381 \mathrm{X}$ & $0,925^{* *}$ \\
IAC 18-Xavantes & $\mathrm{Y}=15,8499+170,701 \sqrt{\mathrm{X}}-44,152 \mathrm{X}$ & $0,843^{* *}$ \\
IAC 24-Tucurui & $\mathrm{Y}=24,0424+153,646 \mathrm{X}-40,9575 \mathrm{X}^{2}$ & $0,944^{* *}$ \\
IAPAR 6-Tapejara & $\mathrm{Y}=38,0589+202,494 \mathrm{X}-63,941 \mathrm{X}^{2}$ & $0,862^{* *}$ \\
IAPAR 17-Caeté & $\mathrm{Y}=79,7569+24,4642 \mathrm{X}+43,7568 \mathrm{X}^{2}$ & $0,828^{* *}$ \\
IAPAR 28-Igapó & $\mathrm{Y}=36,5595+97,7143 \mathrm{X}$ & $0,888^{* *}$ \\
& & \\
\hline
\end{tabular}

A cultivar BR 10-Formosa apresentou menor teor de boro na parte aérea com $0,41 \mathrm{mg} \mathrm{B} / \mathrm{le}$ a seguir apresentou aumentos até maior nivel (Figura $8 \mathrm{a}$ ). As cultivares Anahuac, IAPAR 17-Caeté, mostraram aumentos nos teores de boro, a partir do nível $0,00 \mathrm{mg} \mathrm{B/l}$ (Figura 8a e b). BR 18-Terena e IAC 18-Xavantes responderam positivamente aos níveis de boro, apresentando taxa máxima de crescimento com os níveis 2,10 e $3,74 \mathrm{mg} \mathrm{B} / \mathrm{l}$, respectivamente (Figuras $8 \mathrm{a}$ e d). As cultivares IAC 24- 
Tucuruí e IAPAR 6-Tapejara também apresentaram resposta positiva e com efeito quadrático aos níveis de boro, com taxa de crescimento máxima com os níveis 1,88 e 1,58 mg B/l (Figura 8b e d). As cultivares BR 17-Caiuá e BR 36-Ianomami apresentaram aumentos nos teores de boro a partir dos níveis 0,02 e $0,15 \mathrm{mg} \mathrm{B} / \mathrm{l}$, respectivamente (Figura 8c). As cultivares BR 31-Miriti, IAPAR 28-Igapó, BH 1146, BR 20-Guató e IAC 13-Lorena apresentaram aumentos lineares, dos teores de boro na parte aérea, em função dos níveis desse nutriente na solução nutritiva (Figura 8b, c e d).

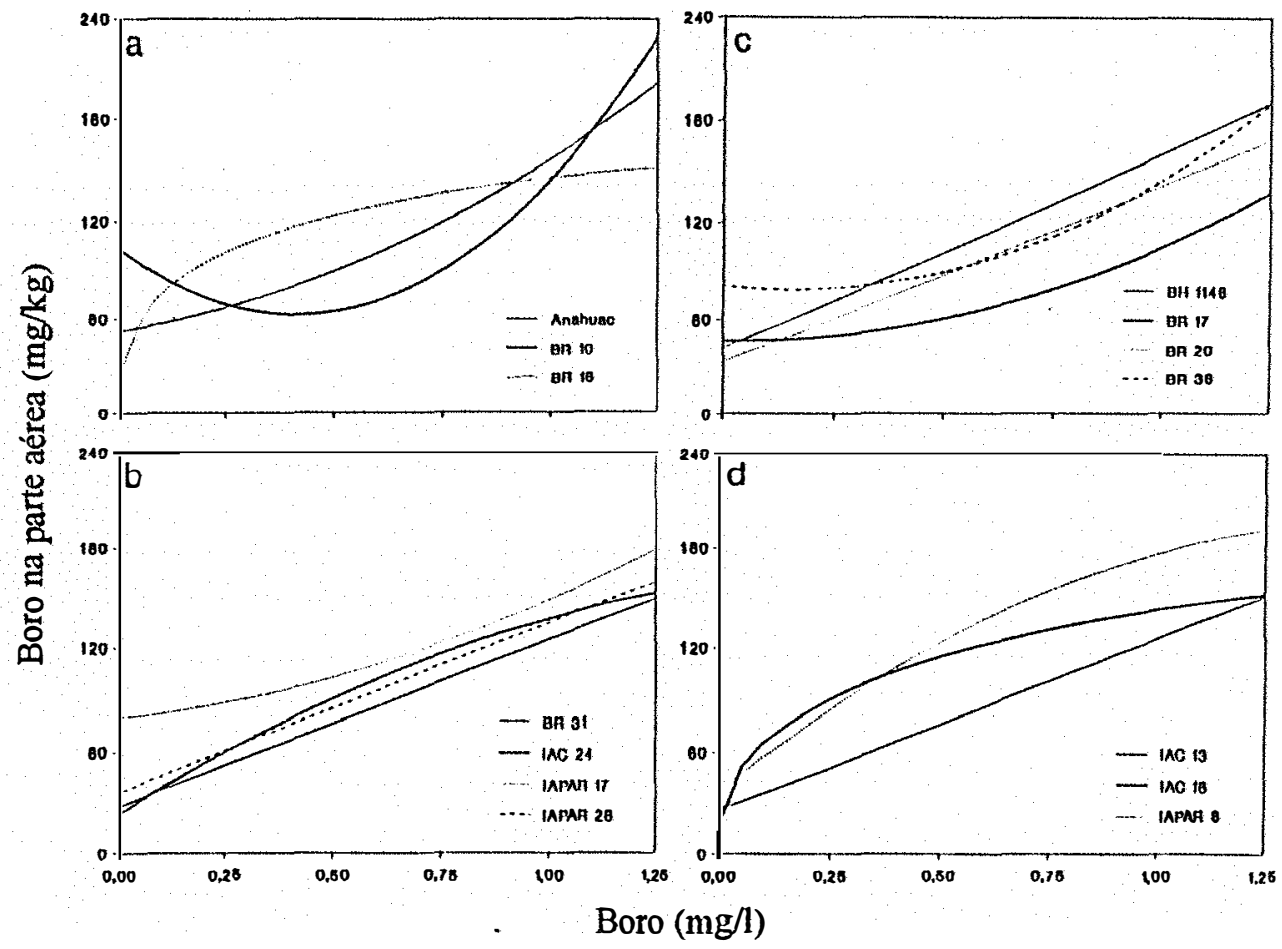

Figura 8. Teor de boro na parte aérea em tunção dos niveis de boro. 


\subsubsection{Massa seca da parte aérea e das raizes}

As análises de variância dos resultados de produção de massa seca da parte aérea e raizes mostraram que houve resposta significativa tanto para niveis quanto para cultivares.

Com relação à parte aérea, embora tenha havido significância para os niveis de boro, não houve ajuste de regressão com os valores obtidos. Com relação às cultivares, as mesmas responderam de forma diferenciada à aplicação do nutriente, conforme apresentado na Tabela 14.

Tabela 14. Produção de massa seca $(\mathrm{g})$ da parte aérea das cultivares em função do uso de boro. Médias de três repetições.

\begin{tabular}{|c|c|c|}
\hline Cultivar & & lédia \\
\hline IAC 18-Xavantes & $0,48 a$ & \\
\hline BR 17-Caiuá & $0,47 a$ & \\
\hline BH 1146 & $0,45 a$ & \\
\hline IAC 13-Lorena & 0,40 & $\mathrm{~b}$ \\
\hline BR 20-Guató & 0,40 & $\mathrm{~b}$ \\
\hline BR 31-Miriti & 0,35 & c \\
\hline Anahuac & 0,34 & c \\
\hline BR 18-Terena & 0,34 & c \\
\hline BR 10-Formosa & 0,31 & $\mathrm{~cd}$ \\
\hline IAPAR 17-Caeté & 0,31 & $\mathrm{~cd}$ \\
\hline IAPAR 6-Tapejara & 0,29 & $\mathrm{~d}$ \\
\hline BR 36-Ianomami & 0,29 & $\mathrm{~d}$ \\
\hline IAC 24-Tucuruí & 0,23 & e \\
\hline IAPAR 28-Igapó & 0,22 & e \\
\hline
\end{tabular}

Médias seguidas de mesma letra não diferem estatisticamente ao nível de $5 \%$ de significância pelo teste de Duncan. 
Pelos resultados de produção de massa seca da parte aérea, as cultivares IAC 18-Xavantes, BR 17-Caiuá e BH 1146 foram as mais produtivas. A seguir estão as cultivares IAC 13-Lorena e BR 20-Guató. Formando o terceiro grupo estão as cultivares BR 31-Miriti, Anahuac, BR 18-Terena, BR 10-Formosa e IAPAR 17-Caeté. Essas duas últimas não diferiram estatisticamente do grupo seguinte, formado por IAPAR 6-Tapejara e BR 36-Ianomami. Por último, formando o grupo das menos produtivas, estão a IAC 24-Tucuruí e IAPAR 28-Igapó.

Na produção de massa seca das raízes, cujos dados estão apresentados na Tabela 15, houve resposta significativa para níveis de boro, variedades e significância para a interação entre ambos os fatores.

Observando-se os dados da Tabela 15,verifica-se que a cultivar Anahuac apresentou a maior produção de massa seca das raízes, com o nível 0,25 mg B/l BH 1146 apresentou maior produção no nível $1,25 \mathrm{mg} \mathrm{B//} \mathrm{porém} \mathrm{não} \mathrm{diferiu} \mathrm{de}$ $0,25 \mathrm{mg} \mathrm{B} / \mathrm{l}$ e foi estatisticamente superior aos demais. Para as demais cultivares as produções de massa seca no nível zero foram maiores ou não diferiram estatisticamente dos níveis mais elevados de boro.

YADAV \& MANCHANDA (1979) verificaram que a produção relativa, tanto de palha quanto de grãos, diminuiu com o aumento das doses de boro. 
Tabela 15. Produção de massa seca (g) das raízes das cultivares em função dos níveis de boro. Médias de três repetições.

\begin{tabular}{|c|c|c|c|c|}
\hline \multirow{2}{*}{ Cultivar } & \multicolumn{4}{|c|}{ Boro (mg/l) } \\
\hline & 0,00 & 0,25 & 0,50 & 1,25 \\
\hline Anahuac & $0,30 b^{1}$ & $0,37 \mathrm{a}$ & $0,30 \mathrm{~b}$ & $0,33 \mathrm{ab}$ \\
\hline BH 1146 & $0,30 \mathrm{~b}$ & $0,37 \mathrm{a}$ & $0,30 \mathrm{~b}$ & $0,40 \mathrm{a}$ \\
\hline BR 10-Formosa & $0,30 \mathrm{a}$ & $0,27 \mathrm{a}$ & $0,20 \mathrm{~b}$ & $0,30 \mathrm{a}$ \\
\hline BR 17-Caiuá & $0,37 \mathrm{a}$ & $0,40 \mathrm{a}$ & $0,30 \mathrm{~b}$ & $0,40 \mathrm{a}$ \\
\hline BR 18-Terena & $0,40 \mathrm{a}$ & $0,33 \mathrm{bc}$ & $0,27 \mathrm{c}$ & $0,37 \mathrm{ab}$ \\
\hline BR 20-Guató & $0,37 \mathrm{a}$ & $0,40 \mathrm{a}$ & $0,37 \mathrm{a}$ & $0,40 \mathrm{a}$ \\
\hline BR 31-Miriti & $0,30 \mathrm{a}$ & $0,30 \mathrm{a}$ & $0,20 \mathrm{a}$ & $0,30 \mathrm{a}$ \\
\hline BR 36-Ianomami & $0,33 \mathrm{a}$ & $0,30 \mathrm{a}$ & $0,20 \mathrm{~b}$ & $0,30 \mathrm{a}$ \\
\hline IAC 13-Lorena & $0,37 \mathrm{a}$ & $0,33 \mathrm{ab}$ & $0,27 \mathrm{~b}$ & $0,37 \mathrm{a}$ \\
\hline IAC 18-Xavantes & $0,50 \mathrm{a}$ & $0,40 \mathrm{~b}$ & $0,33 \mathrm{c}$ & $0,43 \mathrm{~b}$ \\
\hline IAC 24-Tucuruí & $0,30 \mathrm{a}$ & $0,27 \mathrm{ab}$ & $0,20 \mathrm{c}$ & $0,23 \mathrm{bc}$ \\
\hline IAPAR 6-Tapejara & $0,40 \mathrm{a}$ & $0,37 \mathrm{a}$ & $0,30 \mathrm{~b}$ & $0,37 \mathrm{a}$ \\
\hline IAPAR 17-Caeté & 0,33 a & $0,33 \mathrm{a}$ & $0,27 \mathrm{a}$ & $0,30 \mathrm{a}$ \\
\hline IAPAR 28-Igapó & $0,30 \mathrm{a}$ & $0,30 \mathrm{a}$ & $0,20 \mathrm{~b}$ & $0,20 \mathrm{~b}$ \\
\hline
\end{tabular}

Médias seguidas da mesma letra, na horizontal, não diferem pelo teste de Duncan, ao nível de $5 \%$ de significância. 


\subsubsection{Acúmulo de boro na parte aérea e nas raízes}

As análises de variância do acúmulo de boro na parte aérea e raízes mostraram que houve significância para os níveis de boro aplicados, as cultivares responderam de modo diferenciado e que houve significância para a interação entre cultivares e níveis de boro.

Com relação ao acúmulo de boro na parte aérea o desdobramento das interações mostrou que as cultivares se comportaram de maneiras distintas. Na Tabela 16 estão apresentadas as equações de regressão entre os níveis de boro e o acúmulo do nutriente na parte aérea das plantas.

Tabela 16. Equações de regressão e coeficientes de determinação $\left(R^{2}\right)$ entre níveis e acúmulo de boro pela parte aérea.

\begin{tabular}{lll}
\hline Cultivar & \multicolumn{1}{c}{ Equação } & $\mathrm{R}^{2}$ \\
\hline Anahuac & $\mathrm{Y}=18,27+10,5695 \mathrm{X}+23,1366 \mathrm{X}^{2}$ & $0,841^{* *}$ \\
BR 10-Formosa & $\mathrm{Y}=30,8663-61,7446 \mathrm{X}+77,6662 \mathrm{X}^{2}$ & $0,972^{* *}$ \\
BR 18-Terena & $\mathrm{Y}=8,8169+57,0337 \sqrt{\mathrm{X}}-15,0229 \mathrm{X}$ & $0,773^{*}$ \\
BR 31-Miriti & $\mathrm{Y}=9,09167+35,6667 \mathrm{X}$ & $0,950^{* *}$ \\
IAC 24-Tucuruí & $\mathrm{Y}=5,35119+27,4476 \mathrm{X}$ & $0,937^{* *}$ \\
IAPAR 17-Caeté & $\mathrm{Y}=24,0199+4,61668 \mathrm{X}+18,8198 \mathrm{X}^{2}$ & $0,850^{* *}$ \\
IAPAR 28-Igapó & $\mathrm{Y}=7,68571+22,8952 \mathrm{X}$ & $0,647^{* *}$ \\
BH 1146 & $\mathrm{Y}=18,356+56,3714 \mathrm{X}$ & $0,811^{* *}$ \\
BR 17-Caiuá & $\mathrm{Y}=19,2381+7,61515 \mathrm{X}+25,5381 \mathrm{X}^{2}$ & $0,877^{* *}$ \\
BR 20-Guató & $\mathrm{Y}=13,7107+43,8286 \mathrm{X}$ & $0,822^{* *}$ \\
BR 36-Ianomami & $\mathrm{Y}=23,1631-14,875 \mathrm{X}+33,8298 \mathrm{X}^{2}$ & $0,843^{* *}$ \\
IAC 13-Lorena & $\mathrm{Y}=10,1845+40,4476 \mathrm{X}$ & $0,922^{* *}$ \\
IAC 18-Xavantes & $\mathrm{Y}=17,6155+55,1524 \mathrm{X}$ & $0,742^{* *}$ \\
IAPAR 6-Tapejara & $\mathrm{Y}=11,8548+41,1905 \mathrm{X}$ & $0,886^{* *}$ \\
\hline
\end{tabular}


A cultivar BR 10-Formosa apresentou pequeno decréscimo no acúmulo de boro na parte aérea até o nivel de $0,40 \mathrm{mg} \mathrm{B} / \mathrm{e}$ a partir desse ponto as taxas de acúmulo foram crescentes a cada nível de boro avaliado (Figura 9a). Anahuac, IAPAR 17-Caeté, BR 17-Caiuá também tiveram um comportamento de forma quadrática com relação aos níveis de boro, apresentando inicialmente uma taxa de crescimento muito pequena até o nível $0,50 \mathrm{mg} \mathrm{B} / \mathrm{le}$ a partir daí com incrementos maiores (Figuras 9a, b e c). BR 18-Terena teve taxa de acúmulo mais acentuada até o nível $0,25 \mathrm{mg} \mathrm{B} / \mathrm{e}$ a seguir as taxas de acréscimo foram menores, atingindo o maior acúmulo com o nível 3,60 mg B/l (Figura 9a). As demais cultivares IAPAR 28-Igapó, IAC 24-Tucuruí, BR 31-Miriti, BH 1146, BR 20-Guató, IAC 18-Xavantes, IAPAR 6-Tapejara e IAC 13Lorena mostraram efeito linear ao acúmulo de boro, apresentando taxas de crescimento distintas em função dos níveis de boro avaliados (Figura 9b, c e d).

Em relação ao acúmulo de boro pelas raízes o desdobramento das interações mostrou o comportamento bem diferenciado pelas cultivares. Na Tabela 17 são apresentadas as equações de regressão que melhor se ajustaram às cultivares, e na Tabela 18 estão os resultados relativos às demais cultivares. Nesta última tabela verificase que para as cultivares BH 1146, BR 18-Terena e IAC 18-Xavantes o maior acúmulo de boro nas raízes ocorreu no nível $0,25 \mathrm{mg} \mathrm{B/1}$. BR 20-Guató teve maior acúmulo de boro no nível $0,50 \mathrm{mg} \mathrm{B} / \mathrm{l}$, enquanto que com a $\mathrm{BR} 31$-Miriti isso ocorreu no nível zero. 


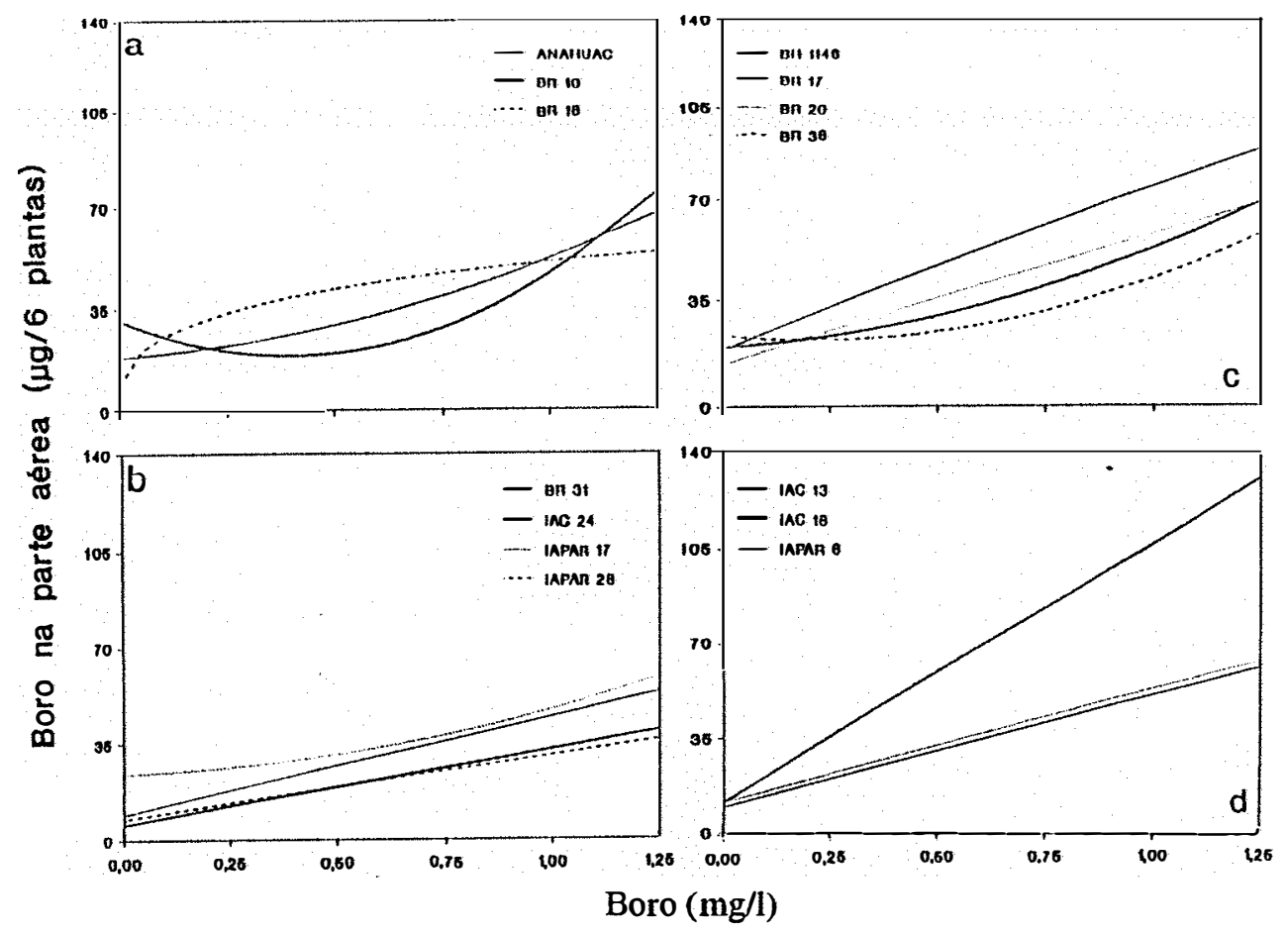

Figura 9. Acúmulo de boro na parte aérea em função dos níveis de boro.

Tabela 17. Equações de regressão e coeficientes de determinação $\left(R^{2}\right)$ entre níveis e acúmulo de boro pelas raízes.

\begin{tabular}{lcc}
\hline Cultivar & \multicolumn{1}{c}{ Equação } & $\mathrm{R}^{2}$ \\
\hline Anahuac & $\mathrm{Y}=71,9353-123,037 \mathrm{X}+78,1686 \mathrm{X}^{2}$ & $0,672 * *$ \\
BR 10-Formosa & $\mathrm{Y}=56,1381-133,985 \mathrm{X}+86,8714 \mathrm{X}^{2}$ & $0,718^{* *}$ \\
BR 17-Caiuá & $\mathrm{Y}=101,273-211,606 \mathrm{X}+138,339 \mathrm{X}^{2}$ & $0,834^{* *}$ \\
BR 36-Ianomami & $\mathrm{Y}=78,9893-168,731 \mathrm{X}+104,589 \mathrm{X}^{2}$ & $0,921^{* *}$ \\
IAC 13-Lorena & $\mathrm{Y}=83,9926-150,028 \mathrm{X}+93,8592 \mathrm{X}^{2}$ & $0,645^{* *}$ \\
IAC 24-Tucuruí & $\mathrm{Y}=27,25+75,5692 \sqrt{\mathrm{X}}-79,4044 \mathrm{X}$ & $0,622^{*}$ \\
IAPAR 6-Tapejara & $\mathrm{Y}=31,5499+83,2794 \sqrt{\mathrm{X}}-51,1679 \mathrm{X}$ & $0,725^{* *}$ \\
IAPAR 17-Caeté & $\mathrm{Y}=1 /(0,0202373+0,0294308 \mathrm{X})$ & $0,659^{* *}$ \\
IAPAR 28-Igapó & $\mathrm{Y}=1 /(0,0112291+0,0295582 \mathrm{X})$ & $0,906^{* *}$ \\
\hline
\end{tabular}


Tabela 18. Acúmulo de boro nas raízes em função dos níveis de boro aplicados. Médias de três repetições.

\begin{tabular}{lcccc}
\hline \multirow{2}{*}{ Cultivar } & \multicolumn{4}{c}{ Boro (mg/l) } \\
\cline { 2 - 5 } & 0,00 & 0,25 & 0,50 & 1,25 \\
\hline BH 1146 & 51,9 & 81,8 & 28,2 & 38,4 \\
BR 18-Terena & 48,0 & 70,9 & 44,0 & 39,6 \\
BR 20-Guató & 57,3 & 54,0 & 66,2 & $.38,8$ \\
BR 31-Miriti & 63,6 & 56,4 & 31,8 & 47,1 \\
IAC 18-Xavantes & 55,5 & 74,0 & 56,4 & 47,7 \\
\hline
\end{tabular}

As cultivares BR 17-Caiuá, IAC 13-Lorena, BR 36-Ianomami, Anahuac e BR 10-Formosa tiveram comportamento semelhante e o acúmulo de boro nas raízes decresceu até os níveis de 0,$76 ; 0,89 ; 0,81 ; 0,79$ e $0,77 \mathrm{mg} \mathrm{B} / 1$, respectivamente e depois teve um pequeno acréscimo (Figura 10a e b). IAPAR 6-Tapejara apresentou aumento de acúmulo até o nível $0,66 \mathrm{mg} \mathrm{B} / 1$ e após esse nível praticamente não houve aumento na taxa de acúmulo, permanecendo os valores praticamente constantes (Figura 10a). IAC 24-Tucuruí também teve taxa de crescimento no acúmulo de boro nas raízes até o nível de $0,23 \mathrm{mg} \mathrm{B} / 1$ e após esse nível houve decréscimo no acúmulo do nutriente em função dos níveis avaliados (Figura 10c). IAPAR 28-Igapó e IAPAR 17-Caeté apresentaram comportamento semelhante e os valores foram decrescentes com os aumentos dos níveis de boro (Figura 10c). 

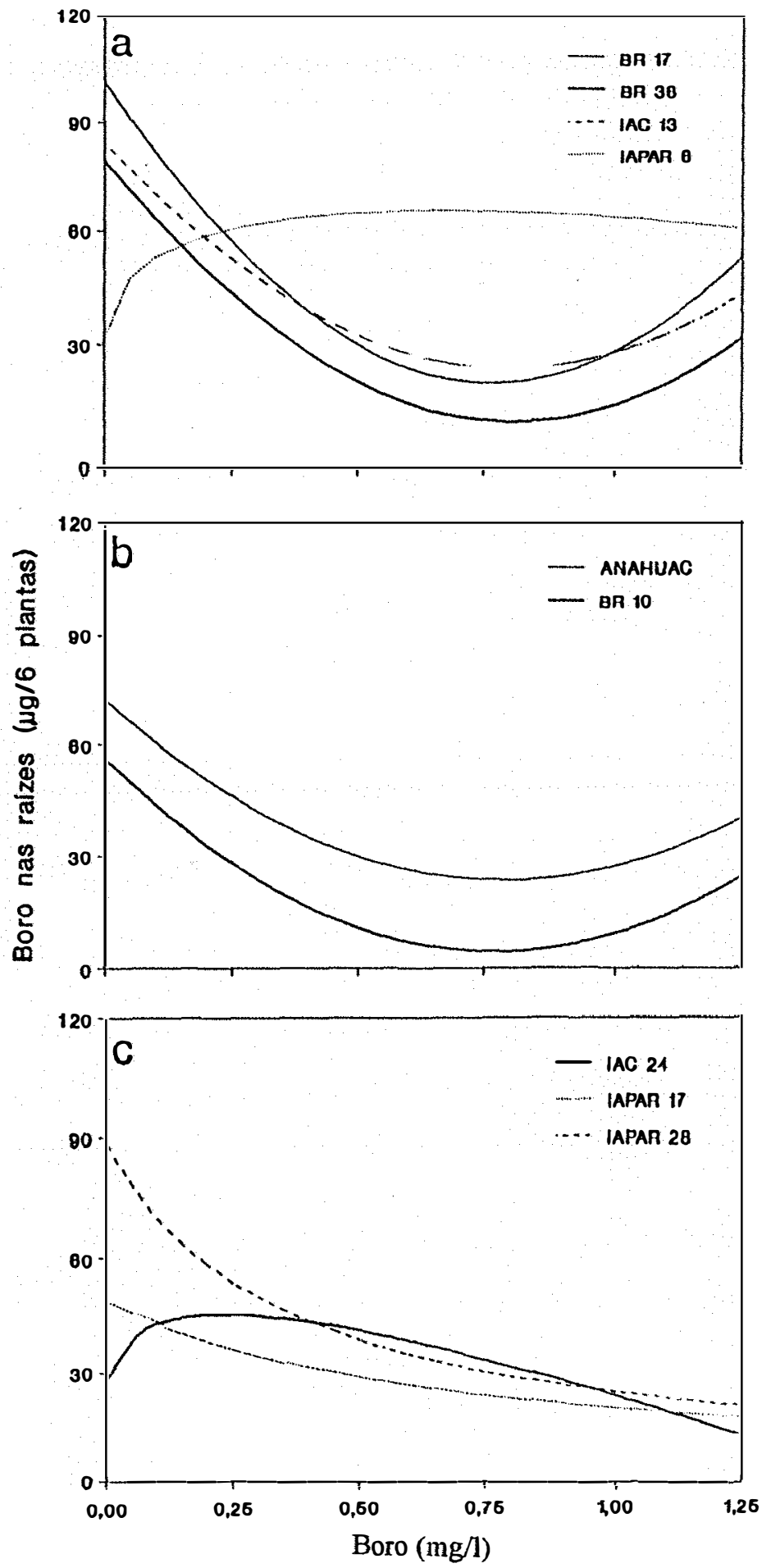

Figura 10. Acúmulo de boro nas raizes em função dos níveis de boro aplicados. 


\subsubsection{Eficiência de utilização de boro}

A análise de variância dos resultados mostrou que os níveis de boro influíram significativamente na eficiência de utilização desse nutriente, as cultivares responderam de modo diferenciado e houve significância para a interação entre os níveis e as cultivares avaliadas. $\mathrm{O}$ desdobramento das interações evidenciou o comportamento de cada uma das cultivares dentro dos níveis de boro (Tabela 19).

Tabela 19. Equações de regressão e coeficientes de determinação $\left(R^{2}\right)$ entre níveis e eficiência de utilização de boro pelas plantas.

\begin{tabular}{lll}
\hline Cultivar & \multicolumn{1}{c}{ Equação } & \multicolumn{1}{c}{$\mathrm{R}^{2}$} \\
\hline Anahuac & $\mathrm{Y}=1 /(0,12386+0,377529 \mathrm{X})$ & $0,820^{* *}$ \\
BH 1146 & $\mathrm{Y}=11,2296-18,3914 \mathrm{X}+9,23963 \mathrm{X}^{2}$ & $0,705^{* *}$ \\
BR 10-Formosa & $\mathrm{Y}=2,90897+8,77146 \sqrt{\mathrm{X}}-9,04038 \mathrm{X}$ & $0,884^{* *}$ \\
BR 17-Caiuá & $\mathrm{Y}=8,82909+7,6019 \sqrt{\mathrm{X}}-11,0476 \mathrm{X}$ & $0,754^{*}$ \\
BR 18-Terena & $\mathrm{Y}=16,0598-33,5469 \sqrt{\mathrm{X}}+19,2894 \mathrm{X}$ & $0,911^{* *}$ \\
BR 20-Guató & $\mathrm{Y}=9,48033-9,34306 \mathrm{X}+2,927 \mathrm{X}^{2}$ & $0,818^{* *}$ \\
BR 31-Miriti & $\mathrm{Y}=11,7097-20,0225 \mathrm{X}+10,1864 \mathrm{X}^{2}$ & $0,811^{* *}$ \\
BR 36-Ianomami & $\mathrm{Y}=1 /(0,262556+0,27204 \mathrm{X})$ & $0,417^{*}$ \\
IAC 13-Lorena & $\mathrm{Y}=1 /(0,0716811+0,240809 \mathrm{X})$ & $0,864^{* *}$ \\
IAC 18-Xavantes & $\mathrm{Y}=41,353-96,0966 \sqrt{\mathrm{X}}+56,2379 \mathrm{X}$ & $0,873^{* *}$ \\
IAC 24-Tucuruí & $\mathrm{Y}=13,1252-26,4628 \sqrt{\mathrm{X}}+14,7012 \mathrm{X}$ & $0,877^{* *}$ \\
IAPAR 6-Tapejara & $\mathrm{Y}=11,4847-23,0804 \sqrt{\mathrm{X}}+13,0249 \mathrm{X}$ & $0,849^{* *}$ \\
IAPAR 17-Caeté & $\mathrm{Y}=1 /(0,246321+0,23408 \mathrm{X})$ & $0,678^{* *}$ \\
IAPAR 28-Igapó & $\mathrm{Y}=7,37404-14,845 \mathrm{X}+8,11404 \mathrm{X}^{2}$ & $0,652^{* *}$ \\
\hline
\end{tabular}

De maneira geral, em todas as cultivares a eficiência de utilização diminuiu com o aumento dos níveis de boro. BR 10-Formosa e BR 17-Caiuá tiveram comportamento semelhante, sendo que a última apresentou valores mais elevados 
(Figura 11a e c). Anahuac e BR 20-Guató também apresentaram comportamento semelhante, não havendo diferença significativa entre os níveis zero e $0,25 \mathrm{mg} \mathrm{B} /$, porém diferente dos demais em ambas as cultivares (Figura 11a e c). BR 18-Terena, IAC 24-Tucuruí e IAPAR 6-Tapejara comportaram-se de maneira semelhante, com eficiência de utilização maior no nível zero e decrescendo rapidamente até o nível 0,25 mg B/l e a partir daí com pouca variação (Figura 11a, b e d). BR 31-Miriti, IAPAR 28-Igapó, BH 1146 e IAC 13-Lorena decresceram até o nível aproximado de $0,70 \mathrm{mg} \mathrm{B} / 1$ e após mantiveram eficiência de utilização praticamente constante, entretanto a cultivar IAPAR 28-Igapó apresentou valores menores que as demais (Figuras 11b, c e d). IAPAR 17-Caeté e BR 36-Ianomami praticamente não tiveram alteração na eficiência de utilização em função dos níveis de boro (Figura 11b e c). A cultivar IAC 18-Xavantes foi a que apresentou comportamento mais distinto, com eficiência alta no nível zero diminuindo drasticamente até o nível $0,25 \mathrm{mg} \mathrm{B} / \mathrm{l}$ e chegando a praticamente zero após o nível 0,50 mg B/l (Figura 11d). 


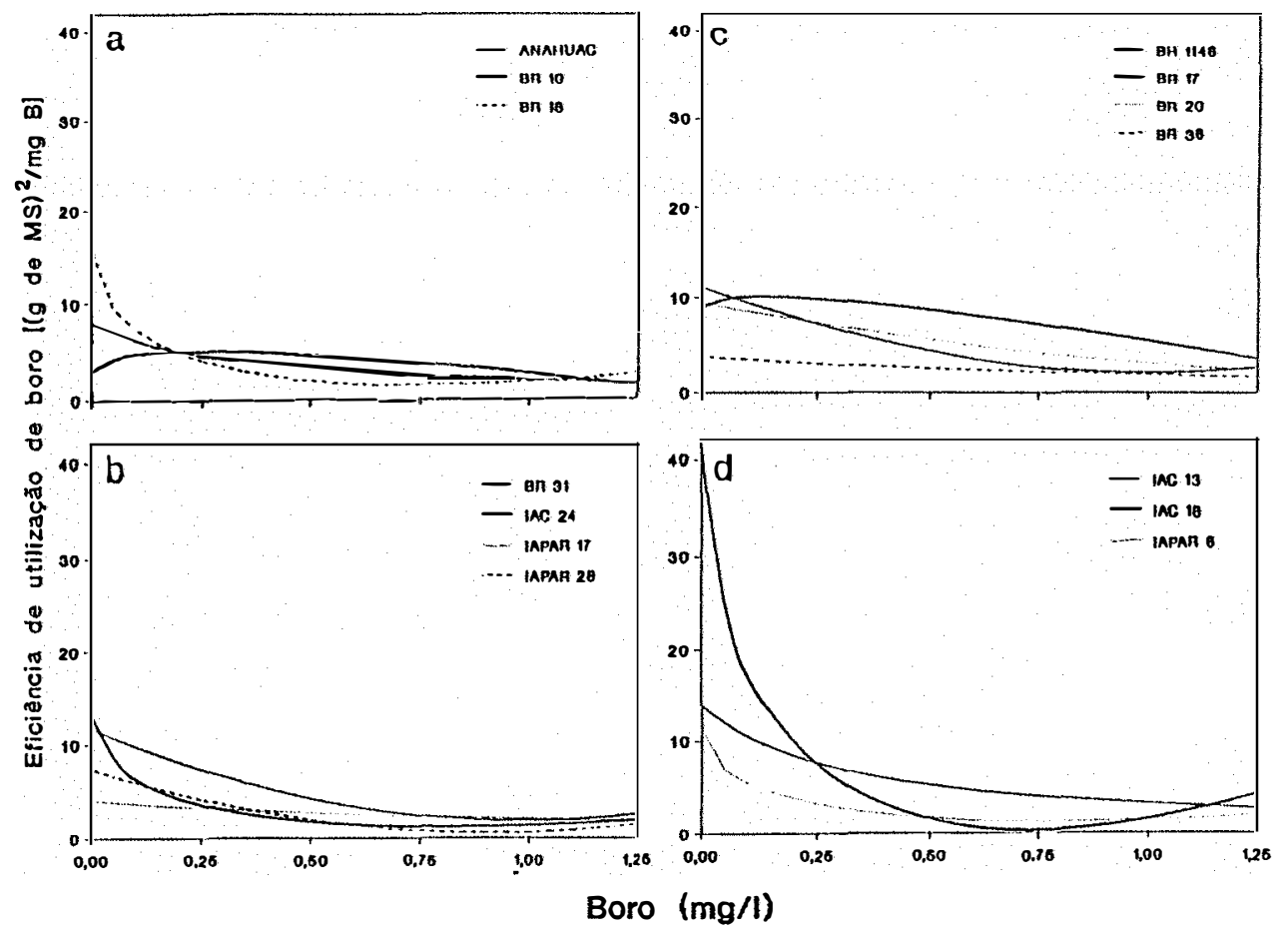

Figura 11. Eficiência de utilização de boro pela parte aérea de cultivares de trigo.

\subsubsection{Zinco}

\subsubsection{Comprimento da parte aérea e da raiz}

As análises de variância dos resultados mostraram que não houve resposta significativa aos níveis de zinco utilizados, porém as cultivares tiveram comportamento diferenciado em relação ao nutriente. Na Tabela 20 são apresentados os resultados referentes ao desenvolvimento da parte aérea das plantas. 
Tabela 20. Comprimento da parte aérea $(\mathrm{cm})$ das cultivares em função da aplicação de zinco. Médias de três repetições.

\begin{tabular}{|c|c|c|}
\hline Cultivar & \multicolumn{2}{|c|}{ Média } \\
\hline IAC 18-Xavantes & $27,6 \mathrm{a}$ & \\
\hline BH 1146 & $26,6 \mathrm{a}$ & \\
\hline BR 31-Miriti & 24,3 & $\mathrm{~b}$ \\
\hline BR 20-Guató & 23,8 & bc \\
\hline BR 36-Ianomami & 23,7 & bc \\
\hline Anahuac & 23,3 & bcd \\
\hline EMBRAPA 10-Guajá & 23,0 & bcd \\
\hline BR 30-Cadiuéu & 22,6 & $\mathrm{~cd}$ \\
\hline IAPAR 6-Tapejara & 21,9 & $\mathrm{de}$ \\
\hline IAPAR 17-Caeté & 21,8 & de \\
\hline IAC 13-Lorena & 20,8 & e \\
\hline BR 18-Terena & 20,7 & e \\
\hline IAPAR 28-Igapó & 20,6 & e \\
\hline BR 17-Caiuá & 20,2 & e \\
\hline
\end{tabular}

Médias seguidas de mesma letra não diferem pelo teste de Duncan, ao nível de $5 \%$ de significância.

Pelos resultados apresentados na Tabela 20 pode-se separar as cultivares em três grupos, em função do desenvolvimento da parte aérea. IAC 18Xavantes e BH 1146 como as mais produtivas; IAPAR 6-Tapejara, IAPAR 17-Caeté, IAC 13-Lorena, BR 18-Terena, IAPAR 28-Igapó e BR 17-Caiuá as que apresentaram menor desenvolvimento vegetativo e as demais situando-se numa posição intermediária. As cultivares que apresentaram melhor desenvolvimento pertencem ao ciclo precoce e as menos produtivas aos ciclos intermediário e precoce.

Com relação ao comprimento das raízes também pode-se dividir as cultivares em três grupos, porém diferentes daqueles citados na parte aérea. As cultivares IAC 18-Xavantes e BH 1146 também apresentaram maior desenvolvimento, juntamente 
com IAPAR 28-Igapó, BR 31-Miriti, BR 20-Guató e IAPAR 6-Tapejara. Anahuac apresentou menor desenvolvimento radicular $\mathrm{e}$ as demais cultivares tiveram comprimentos intermediários às citadas (Tabela 21).

Tabela 21. Comprimento das raízes $(\mathrm{cm})$ das cultivares em função da aplicação de zinco. Médias de três repetições.

\begin{tabular}{ll}
\hline Cultivar & Média \\
\hline IAC 18-Xavantes & $42,4 \mathrm{a}$ \\
IAPAR 28-Igapó & $41,9 \mathrm{a}$ \\
BH 1146 & $41,7 \mathrm{a}$ \\
BR 31-Miriti & $41,7 \mathrm{a}$ \\
BR 20-Guató & $40,9 \mathrm{a}$ \\
IAPAR 6-Tapejara & $40,2 \mathrm{a}$ \\
BR 17-Caiuá & $36,9 \mathrm{~b}$ \\
BR 36-Ianomami & $35,6 \mathrm{bc}$ \\
IAPAR 17-Caeté & $35,5 \mathrm{bc}$ \\
BR 30-Cadiuéu & $35,1 \mathrm{bcd}$ \\
IAC 13-Lorena & $34,1 \mathrm{~cd}$ \\
BR 18-Terena & $33,4 \mathrm{~cd}$ \\
EMBRAPA 10-Guajá & $33,1 \mathrm{~d}$ \\
Anahuac & $30,8 \mathrm{~d}$ \\
\hline
\end{tabular}

Médias seguidas de mesma letra não diferem pelo teste de Duncan, ao nível de $5 \%$ de significância.

\subsubsection{Teor de zinco na parte aérea e nas raizes}

Pelos resultados da análise de variância verifica-se que os níveis de zinco influíram no teor desse nutriente tanto na parte aérea como nas raízes. As cultivares também responderam à aplicação de zinco e houve efeito interativo entre os 
níveis e as cultivares. $\mathrm{O}$ desdobramento das interações mostrou o comportamento distinto de cada cultivar (Tabelas 22 e 23), dentro dos níveis de zinco.

Tabela 22. Equações de regressão e coeficientes de determinação $\left(R^{2}\right)$ entre níveis e eficiência de utilização de zinco pelas plantas.

\begin{tabular}{lcc}
\hline Cultivar & \multicolumn{1}{c}{ Equação } & $\mathrm{R}^{2}$ \\
\hline Anahuac & $\mathrm{Y}=35,9454-289,576 \mathrm{X}+4436,36 \mathrm{X}^{2}$ & $0,689^{* *}$ \\
BH 1146 & $\mathrm{Y}=38,2-342,667 \mathrm{X}+4000 \mathrm{X}^{2}$ & $0,501^{*}$ \\
EMBRAPA 10-Guajá & $\mathrm{Y}=28,8+221,714 \mathrm{X}$ & $0,690^{* *}$ \\
BR 17-Caiuá & $\mathrm{Y}=29,3333+118,095 \mathrm{X}$ & $0,571^{* *}$ \\
BR 18-Terena & $\mathrm{Y}=30,0+228,571 \mathrm{X}$ & $0,719^{* *}$ \\
BR 20-Guató & $\mathrm{Y}=26,1333+164,571 \mathrm{X}$ & $0,601^{* *}$ \\
BR 31-Miriti & $\mathrm{Y}=28,8364+617,939 \mathrm{X}-4024,24 \mathrm{X}^{2}$ & $0,771^{* *}$ \\
BR 36-Ianomami & $\mathrm{Y}=22,6364+720,605 \mathrm{X}-3757,57 \mathrm{X}^{2}$ & $0,836^{* *}$ \\
IAC 13-Lorena & $\mathrm{Y}=24,9091+475,151 \mathrm{X}-1939,39 \mathrm{X}^{2}$ & $0,821^{* *}$ \\
IAC 18-Xavantes & $\mathrm{Y}=17,9091+615,151-3806,06 \mathrm{X}^{2}$ & $0,694^{* *}$ \\
BR 30-Cadiuéu & $\mathrm{Y}=18,8546+518,909 \mathrm{X}-3369,7 \mathrm{X}^{2}$ & $0,741^{* *}$ \\
IAPAR 6-Tapejara & $\mathrm{Y}=18,3818+780,363 \mathrm{X}-4654,54 \mathrm{X}^{2}$ & $0,813^{* *}$ \\
IAPAR 17-Caeté & $\mathrm{Y}=24,1152+941,697 \mathrm{X}-5987,88 \mathrm{X}^{2}$ & $0,835^{* *}$ \\
IAPAR 28-Igapó & $\mathrm{Y}=22,2061+753,212 \mathrm{X}-4315,15 \mathrm{X}^{2}$ & $0,701^{* *}$ \\
\hline
\end{tabular}

As cultivares EMBRAPA 10-Guajá, BR 18-Terena, BR 20-Guató e BR 17-Caiuá apresentaram um comportamento linear e crescente nos teores de zinco na parte aérea, em função dos níveis desse nutriente (Figura 12a e c). As cultivares BR 31Miriti, IAPAR 17-Caeté, BR 30-Cadiuéu, IAPAR 6-Tapejara e IAC 18-Xavantes responderam à aplicação de zinco de forma quadrática, atingindo os valores máximos com o nível de zinco entre 0,077 e $0,084 \mathrm{mg} \mathrm{Zn} / 1$ e com tendência a decréscimo após 
esse ponto (Figura 12a, b e d). Anahuac e BH 1146 também apresentaram resposta de forma quadrática, porém os teores decresceram atingindo os mínimos valores, respectivamente, com os níveis de 0,033 e 0,043 $\mathrm{mg} \mathrm{Zn} / 1$, sendo que após esse mínimo, tiveram comportamento crescente (Figura 12a e c). DELL \& WILSON (1985) observaram comportamento semelhante, com a cultura do trigo. Partindo do nível zero, a concentração de zinco na parte aérea diminuiu nas duas doses menores e aumentou nas doses maiores. IAPAR 28-Igapó, BR 36-Ianomami e IAC 13-Lorena responderam de forma quadrática, atingindo valores máximos com os níveis 0,087 e $0,122 \mathrm{mg} \mathrm{Zn} / \mathrm{l}$ (Figura 12b, c e d).

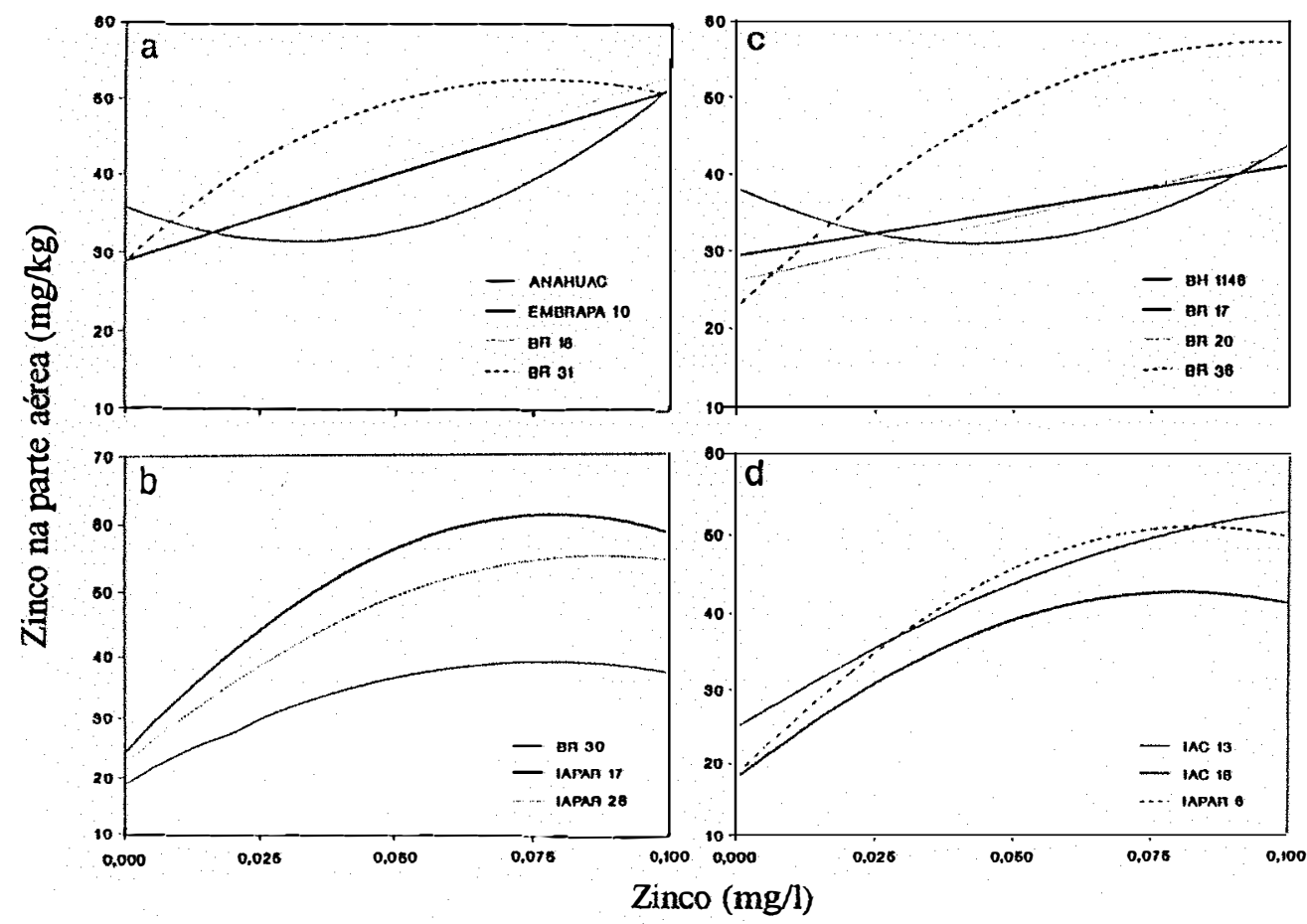

Figura 12. Teor de zinco na parte aérea, em função dos níveis de zinco. 
Tabela 23. Equações de regressão e coeficientes de determinação $\left(\mathbf{R}^{2}\right)$ entre os níveis e o teor de zinco nas raízes.

\begin{tabular}{llc}
\hline Cultivar & \multicolumn{1}{c}{ Equação } & $\mathrm{R}^{2}$ \\
\hline Anahuac & $\mathrm{Y}=24,0667+448,0 \mathrm{X}$ & $0,798^{* *}$ \\
BH 1146 & $\mathrm{Y}=26,9909+1702,85 \mathrm{X}-9393,94 \mathrm{X}^{2}$ & $0,899^{* *}$ \\
EMBRAPA 10-Guajá & $\mathrm{Y}=29,8+315,048 \mathrm{X}$ & $0,681^{* *}$ \\
BR 18-Terena & $\mathrm{Y}=34,6+361,524 \mathrm{X}$ & $0,650^{* *}$ \\
BR 20-Guató & $\mathrm{Y}=51,9303+50,727 \mathrm{X}+3357,57 \mathrm{X}^{2}$ & $0,829^{* *}$ \\
BR 31-Miriti & $\mathrm{Y}=31,4424-120,848 \mathrm{X}+5793,93 \mathrm{X}^{2}$ & $0,841^{* *}$ \\
BR 36-Ianomami & $\mathrm{Y}=38,7030-184,727 \mathrm{X}+6642,42 \mathrm{X}^{2}$ & $0,818^{* *}$ \\
IAC 13-Lorena & $\mathrm{Y}=39,1940-738,547 \mathrm{X}+15781,8 \mathrm{X}^{2}$ & $0,915^{* *}$ \\
IAC 18-Xavantes & $\mathrm{Y}=44,8091-226,849 \mathrm{X}+10193,9 \mathrm{X}^{2}$ & $0,842^{* *}$ \\
BR 30-Cadiuéu & $\mathrm{Y}=35,0576+117,515 \mathrm{X}+4739,39 \mathrm{X}^{2}$ & $0,838^{* *}$ \\
IAPAR 6-Tapejara & $\mathrm{Y}=36,3091-176,849 \mathrm{X}+6860,6 \mathrm{X}^{2}$ & $0,812^{* *}$ \\
IAPAR 17-Caeté & $\mathrm{Y}=47,103-603,394 \mathrm{X}+9842,42 \mathrm{X}^{2}$ & $0,759^{* *}$ \\
IAPAR 28-Igapó & $\mathrm{Y}=38,7849-577,03 \mathrm{X}+7987,88 \mathrm{X}^{2}$ & $0,693^{* *}$ \\
\hline
\end{tabular}

As cultivares Anahuac, BR 18-Terena e EMBRAPA 10-Guajá tiveram aumentos crescentes no teor de zinco nas raízes em função dos níveis aplicados (Figura 13c). As demais cultivares apresentaram resposta de forma quadrática, em função dos niveis de zinco. As cultivares BR 20-Guató e BR 30-Cadiuéu apresentaram aumentos crescentes com taxas de crescimento também crescentes, em função dos níveis de zinco (Figura 13a e d). As cultivares BR 36-Ianomami, IAPAR 6-Tapejara, IAC 18-Xavantes e BR 31-Miriti tiveram aumentos nos teores de zinco nas raizes a partir dos níveis 0,014 ; 0,013; 0,011 e 0,010 mg Zn/l, respectivamente (Figura 13a, b e c). As cultivares IAC 13Lorena, IAPAR 17-Caeté e IAPAR 28-Igapó apresentaram o mínimo teor de zinco nas 
raízes nos níveis 0,$023 ; 0,031$ e $0,036 \mathrm{mg} \mathrm{Zn/1}$ e após esses níveis os teores e taxas de crescimento aumentaram, em função dos níveis de zinco utilizados (Figura 13 b e d). A cultivar BH 1146 apresentou o teor máximo de zinco nas raízes com o nível 0,091 mg $\mathrm{Zn} / \mathrm{l}$ (Figura 13a).

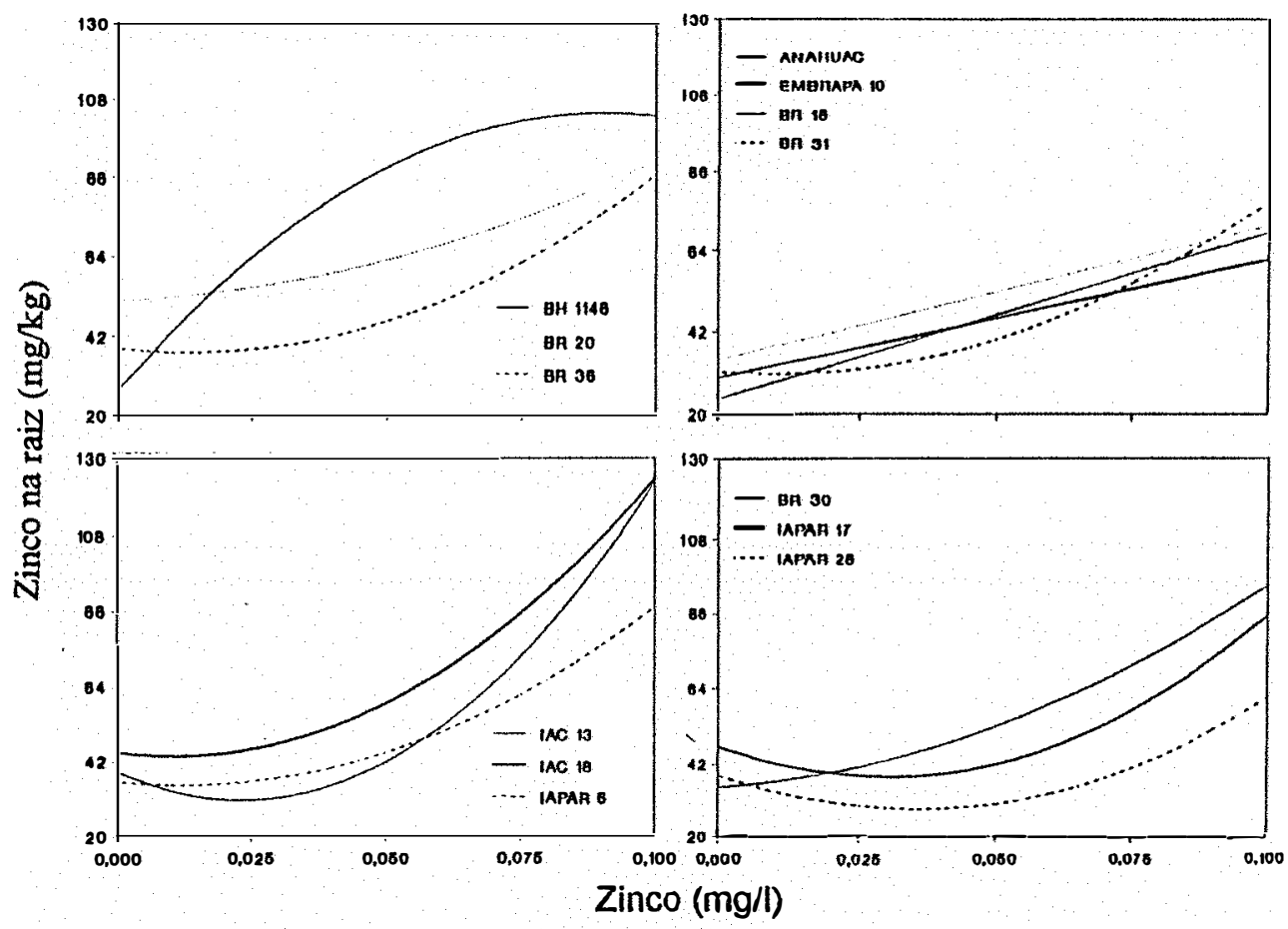

Figura 13. Teor de zinco nas raízes em função dos níveis de zinco. 


\subsubsection{Produção de massa seca da parte aérea e das raízes}

As análises de variância dos resultados de produção de massa seca mostraram que as cultivares responderam de maneira distinta ao zinco, porém não houve resposta aos níveis de zinco utilizados. Na Tabela 24 são apresentados os resultados relativos à produção de massa seca da parte aérea.

Tabela 24. Produção de massa seca da parte aérea (g), das cultivares em função da aplicação de zinco.

\begin{tabular}{|c|c|}
\hline Cultivar & Média \\
\hline BH 1146 & $0,35 \mathrm{a}$ \\
\hline IAC 18-Xavantes & $0,32 \mathrm{ab}$ \\
\hline BR 31-Miriti & $0,32 \mathrm{ab}$ \\
\hline BR 30-Cadiuéu & $0,31 \mathrm{bc}$ \\
\hline IAC 13-Lorena & $0,28 \mathrm{~cd}$ \\
\hline EMBRAPA 10-Guajá & 0,26 \\
\hline Anahuac & 0,26 \\
\hline BR 36-Ianomami & 0,26 \\
\hline BR 18-Terena & 0,26 \\
\hline BR 20-Guató & 0,25 \\
\hline IAPAR 6-Tapejara & 0,25 \\
\hline IAPAR 17-Caiuá & 0,25 \\
\hline IAPAR 17-Caeté & 0,25 \\
\hline IAPAR 28-Igapó & 0,23 \\
\hline
\end{tabular}

Médias seguidas de mesma letra não diferem pelo teste de Duncan, ao nível de $5 \%$ de significância.

Pelos resultados da Tabela 24 verifica-se que a cultivar BH 1146, de ciclo precoce, foi a mais produtiva e a IAPAR 28-Igapó, de ciclo intermediário, a menos produtiva. As demais cultivares situam-se em grupos intermediários e com produções 
diferenciadas. Com relação à produção de massa seca das raízes, o comportamento das cultivares foi semelhante ao que ocorreu na parte aérea. $\mathrm{Na}$ Tabela 25 estão os resultados relativos à massa seca das raizes.

Tabela 25. Produção de massa seca das raízes (g), das cultivares em função da aplicação de zinco.

\begin{tabular}{|c|c|c|}
\hline Cultivar & Mé & édia \\
\hline BH 1146 & 0,20 & $\mathrm{a}$ \\
\hline IAC 18-Xavantes & 0,18 & $a b$ \\
\hline BR 20-Guató & 0,16 & bc \\
\hline BR 31-Miriti & 0,16 & bcd \\
\hline BR 30-Cadiuéu & 0,16 & bcd \\
\hline BR 36-Ianomami & 0,16 & bcd \\
\hline IAPAR 6-Tapejara & 0,15 & cde \\
\hline Anahuac & 0,14 & cde \\
\hline BR 18-Terena & 0,14 & cde \\
\hline BR 17-Caiuá & 0,14 & def \\
\hline EMBRAPA 10-Guajá & 0,14 & def \\
\hline IAC 13-Lorena & 0,13 & ef \\
\hline IAPAR 17-Caeté & 0,13 & ef \\
\hline IAPAR 28-Igapó & 0,12 & $\mathrm{f}$ \\
\hline
\end{tabular}

Médias seguidas de mesma letra não diferem pelo teste de Duncan, ao nível de $5 \%$ de significância.

\subsubsection{Acúmulo de zinco na parte aérea e nas raízes}

As análises de variância do acúmulo de zinco na parte aérea e nas raízes mostraram que ocorreram respostas significativas para os níveis e cultivares em função do zinco. A interação entre níveis e cultivares ocorreu na parte aérea nas raízes. 
As equações de regressão entre acúmulo de zinco em função dos níveis estudados estão nas Tabelas 26 e 27.

Tabela 26. Equações de regressão e coeficientes de determinação $\left(R^{2}\right)$ entre acúmulo de zinco na parte aérea e níveis de zinco na solução nutritiva.

\begin{tabular}{llc}
\hline Cultivar & \multicolumn{1}{c}{ Equação } & $\mathrm{R}^{2}$ \\
\hline Anahuac & $\mathrm{Y}=8,9537-57,7139 \mathrm{X}+1037,09 \mathrm{X}^{2}$ & $0,609^{*}$ \\
BH 1146 & $\mathrm{Y}=13,4874-132,361 \mathrm{X}+1535,51 \mathrm{X}^{2}$ & $0,534^{*}$ \\
EMBRAPA 10-Guajá & $\mathrm{Y}=8,18667+51,8095 \mathrm{X}$ & $0,619^{*}$ \\
BR 17-Caiuá & $\mathrm{Y}=6,75333+45,9428 \mathrm{X}$ & $0,379^{*}$ \\
BR 18-Terena & $\mathrm{Y}=6,17958+168,888 \mathrm{X}-975,273 \mathrm{X}^{2}$ & $0,676^{* *}$ \\
BR 20-Guató & $\mathrm{Y}=5,52897+97,1006 \mathrm{X}-381,091 \mathrm{X}^{2}$ & $0,711^{* *}$ \\
BR 31-Miriti & $\mathrm{Y}=10,3733+76,5333 \mathrm{X}$ & $0,411^{*}$ \\
BR 36-Ianomami & $\mathrm{Y}=4,84103+237,233 \mathrm{X}-1413,58 \mathrm{X}^{2}$ & $0,764^{* *}$ \\
IAC 13-Lorena & $\mathrm{Y}=5,09140+288,119 \mathrm{X}-1963,15 \mathrm{X}^{2}$ & $0,851^{* *}$ \\
IAC 18-Xavantes & $\mathrm{Y}=5,03285+225,263 \mathrm{X}-1324,12 \mathrm{X}^{2}$ & $0,693^{* *}$ \\
BR 30-Cadiuéu & $\mathrm{Y}=5,83406+188,572 \mathrm{X}-1392,48 \mathrm{X}^{2}$ & $0,710^{* *}$ \\
IAPAR 6-Tapejara & $\mathrm{Y}=4,62476+202,932 \mathrm{X}-1236,73 \mathrm{X}^{2}$ & $0,656^{* *}$ \\
IAPAR 17-Caeté & $\mathrm{Y}=5,14097+315,207 \mathrm{X}-2167,76 \mathrm{X}^{2}$ & $0,626^{*}$ \\
IAPAR 28-Igapó & $\mathrm{Y}=4,43194+209,948 \mathrm{X}-1090,18 \mathrm{X}^{2}$ & $0,738^{* *}$ \\
& & \\
\hline
\end{tabular}

Nas cultivares BH 1146 e Anahuac os acúmulos de zinco na parte aérea decresceram até os níveis 0,043 e $0,028 \mathrm{mg} \mathrm{Zn} / \mathrm{l}$, respectivamente, e após esses níveis as taxas de acúmulo foram crescentes (Figura 14a e c). A cultivar BR 20-Guató apresentou aumentos crescentes no acúmulo até o nível estimado de 0,127 mg $\mathrm{Zn} / 1$ (Figura 14a). BR 17-Caiuá, BR 31-Miriti e EMBRAPA 10-Guajá responderam de forma linear e crescente aos níveis de zinco aplicados (Figura 14a e c). IAC 13-Lorena e 
IAPAR 17-Caeté apresentaram aumentos crescentes no acúmulo de zinco até o nível de 0,073 mg Zn/l e com decréscimos após esse nível (Figura 14b e d). As demais cultivares, BR 30-Cadiuéu, IAPAR 6-Tapejara, BR 36-Ianomami, IAC 18-Xavantes, BR 18-Terena e IAPAR 28-Igapó apresentaram aumentos no acúmulo de zinco na parte aérea nos niveis 0,$068 ; 0,082 ; 0,084 ; 0,085,0,087$ e $0,096 \mathrm{mg} \mathrm{Zn/l}$, respectivamente (Figura 14a, $b, c$ ed).

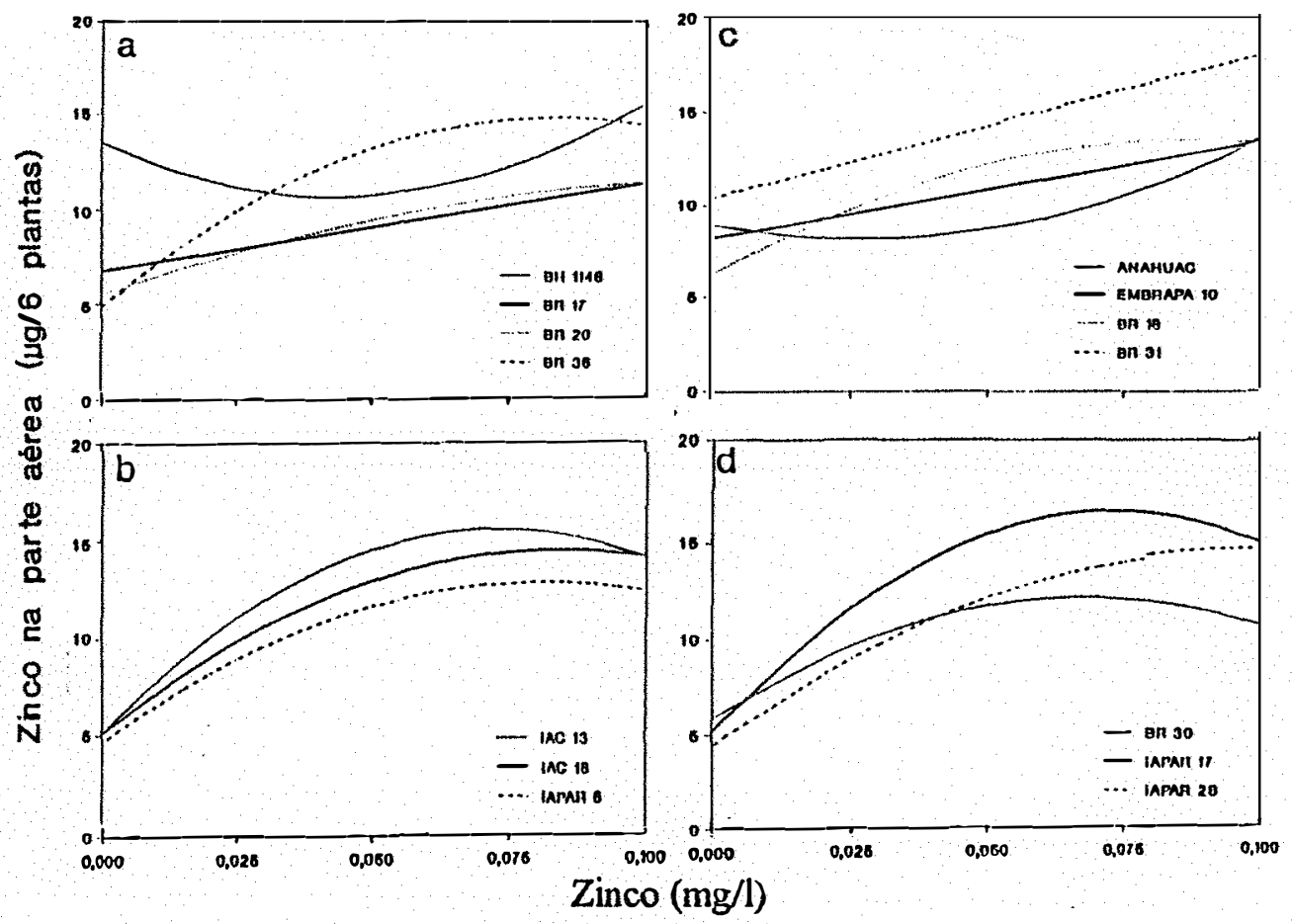

Figura 14. Acúmulo de zinco na parte aérea das plantas de trigo. 
Tabela 27. Equações de regressão e coeficientes de determinação $\left(\mathrm{R}^{2}\right)$ entre acúmulo de zinco nas raízes e níveis de zinco na solução nutritiva.

\begin{tabular}{lll}
\hline Cultivar & \multicolumn{1}{c}{ Equação } & $\mathrm{R}^{2}$ \\
\hline Anahuac & $\mathrm{Y}=3,32133+70,4076 \mathrm{X}$ & $0,746^{* *}$ \\
BH 1146 & $\mathrm{Y}=5,67943+300,891 \mathrm{X}-1575,39 \mathrm{X}^{2}$ & $0,778^{* *}$ \\
EMBRAPA 10-Guajá & $\mathrm{Y}=4,28067+44,5371 \mathrm{X}$ & $0,465^{*}$ \\
BR 18-Terena & $\mathrm{Y}=4,37931+100,04 \mathrm{X}-491,758 \mathrm{X}^{2}$ & $0,728^{* *}$ \\
BR 20-Guató & $\mathrm{Y}=10,3861-70,1879 \mathrm{X}+1143,52 \mathrm{X}^{2}$ & $0,699^{* *}$ \\
BR 30-Cadiuéu & $\mathrm{Y}=6,09661-3,82551 \mathrm{X}+816,484 \mathrm{X}^{2}$ & $0,717^{* *}$ \\
BR 31-Miriti & $\mathrm{Y}=5,24361-59,4188 \mathrm{X}+1383,15 \mathrm{X}^{2}$ & $0,778^{* *}$ \\
BR 36-Ianomami & $\mathrm{Y}=6,51485-52,7637 \mathrm{X}+1171,88 \mathrm{X}^{2}$ & $0,734^{* *}$ \\
IAC 13-Lorena & $\mathrm{Y}=1 /(0,253528-1,74672 \mathrm{X})$ & $0,824^{* *}$ \\
IAC 18-Xavantes & $\mathrm{Y}=7,46382-28,7966 \mathrm{X}+1897,46 \mathrm{X}^{2}$ & $0,742^{* *}$ \\
IAPAR 6-Tapejara & $\mathrm{Y}=5,80085-78,577 \mathrm{X}+1609,21 \mathrm{X}^{2}$ & $0,845^{* *}$ \\
IAPAR 17-Caeté & $\mathrm{Y}=5,64167-43,0333 \mathrm{X}+870,666 \mathrm{X}^{2}$ & $0,540^{*}$ \\
IAPAR 28-Igapó & $\mathrm{Y}=4,59815-91,3097 \mathrm{X}+1277,45 \mathrm{X}^{2}$ & $0,876^{* *}$ \\
& & \\
\hline
\end{tabular}

As cultivares Anahuac e EMBRAPA 10-Guajá tiveram acúmulos crescentes de zinco nas raízes, de forma linear, em função dos níveis de zinco avaliados (Figura 15a). BR 31-Miriti, IAPAR 17-Caeté, BR 36-Ianomami e IAPAR 6-Tapejara comportaram-se de maneira semelhante, com pequenos decréscimos no acúmulo de zinco nas raízes com os níveis $\quad 0,021 ; 0,025 ; 0,022$ e $0,024 \mathrm{mg} \mathrm{Zn/l,} \mathrm{respectivamente,} \mathrm{e,}$ após, com taxas de crescimento aumentando com os níveis de zinco avaliados (Figura $15 a, b, c$ e d).

A cultivar BR 18-Terena apresentou aumentos crescentes no acúmulo de zinco pelas raízes, atingindo o máximo com $0,102 \mathrm{mg} \mathrm{Zn/l} \mathrm{(Figura} \mathrm{15a).} \mathrm{A} \mathrm{cultivar}$ 
BH 1146 atingiu o máximo de acúmulo de zinco nas raízes com o nível de $0,095 \mathrm{mg} \mathrm{Zn/1}$ (Figura 15c). BR 30-Cadiuéu e IAC 18-Xavantes também tiveram comportamento semelhante no acúmulo de zinco nas raízes, com taxas de crescimento a partir dos níveis 0,002 e $0,008 \mathrm{mg} \mathrm{Zn} /$, respectivamente (Figura $15 \mathrm{~b}$ e d). As cultivares BR 20-Guató e IAPAR 28-Igapó apresentaram menor acúmulo de zinco nas raízes com os níveis 0,031 e $0,036 \mathrm{mg} \mathrm{Zn} / \mathrm{l} \mathrm{e}$, após, aumentos nos teores desse nutriente (Figura $15 \mathrm{~b} \mathrm{e} \mathrm{c).}$

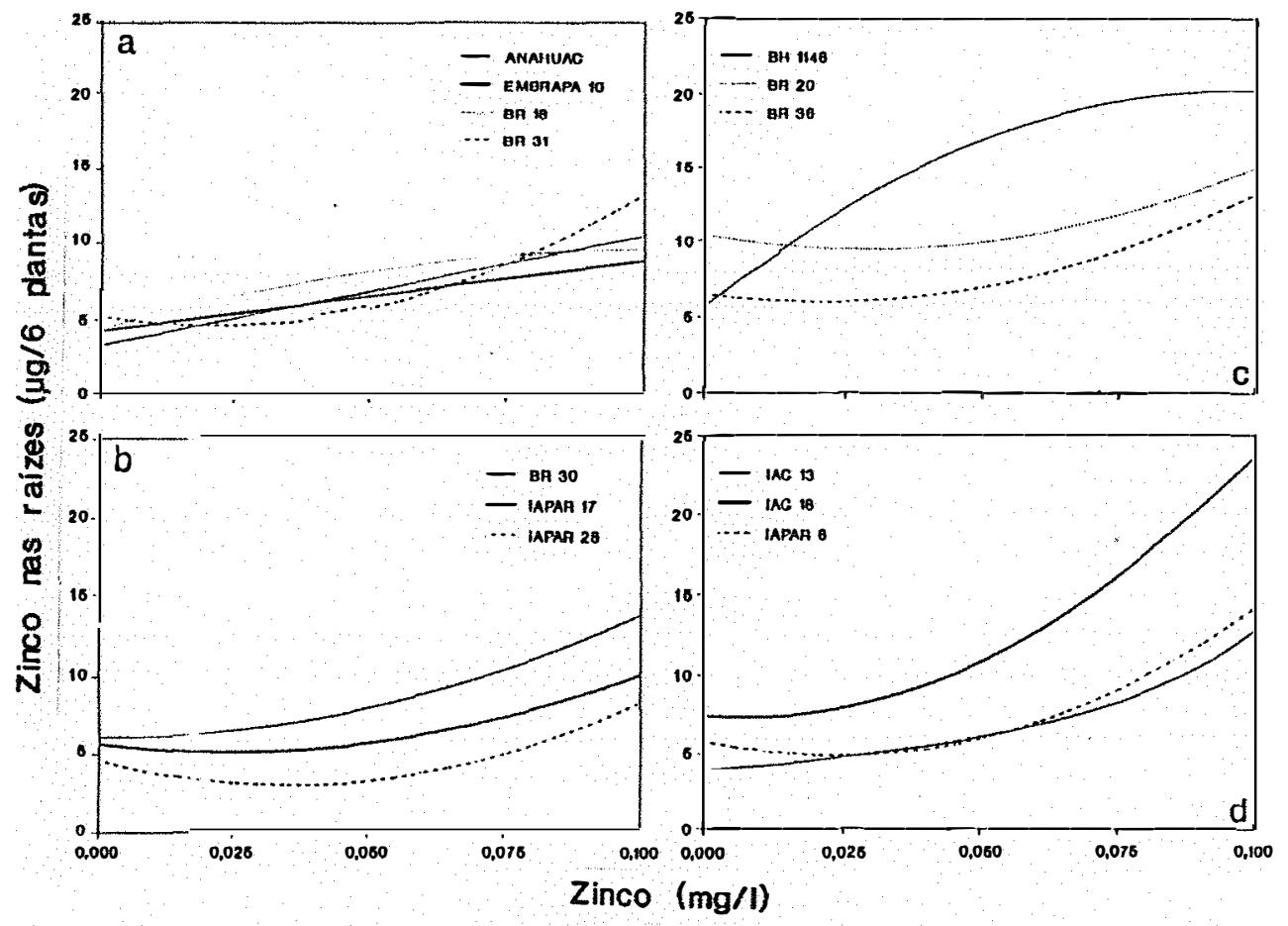

Figura 15. Acúmulo de zinco nas raízes das plantas de trigo. 


\subsubsection{Eficiência de utilização de zinco}

A análise de variância dos resultados de eficiência de utilização de zinco pela parte aérea mostrou que houve diferença entre os níveis e cultivares estudados. Houve também interação significativa entre níveis e cultivares.

Na Tabela 28 são apresentados os desdobramentos das interações para cada cultivar.

Tabela 28 Equações de regressão e coeficientes de determinação $\left(R^{2}\right)$ entre níveis de zinco e acúmulo na parte aérea.

\begin{tabular}{lll}
\hline Cultivar & \multicolumn{1}{c}{ Equação } & \multicolumn{1}{c}{$\mathrm{R}^{2}$} \\
\hline Anahuac & $\mathrm{Y}=6,78918+37,0324 \sqrt{\mathrm{X}}-135,449 \mathrm{X}$ & $0,565^{*}$ \\
EMBRAPA 10-Guajá & $\mathrm{Y}=1 /(0,10145+0,95542 \mathrm{X})$ & $0,620^{* *}$ \\
BR 18-Terena & $\mathrm{Y}=6,85397+60,2673 \mathrm{X}-825,091 \mathrm{X}^{2}$ & $0,517^{*}$ \\
BR 30-Cadiuéu & $\mathrm{Y}=15,4958-172,210 \mathrm{X}+957,211 \mathrm{X}^{2}$ & $0,768^{* *}$ \\
BR 31-Miriti & $\mathrm{Y}=11,4209-40,1341 \sqrt{\mathrm{X}}+79,2275 \mathrm{X}$ & $0,868^{* *}$ \\
BR 36-Ianomami & $\mathrm{Y}=1 /(0,115698+1,18554 \mathrm{X})$ & $0,743^{* *}$ \\
IAC 13-Lorena & $\mathrm{Y}=1 /(0,104295+0,923468 \mathrm{X})$ & $0,390^{*}$ \\
IAC 18-Xavantes & $\mathrm{Y}=14,5687-153,134 \mathrm{X}+900,849 \mathrm{X}^{2}$ & $0,628^{*}$ \\
IAPAR 6-Tapejara & $\mathrm{Y}=13,0189-232,471 \mathrm{X}+1532,97 \mathrm{X}^{2}$ & $0,867^{* *}$ \\
IAPAR 17-Caeté & $\mathrm{Y}=9,07918-135,01 \mathrm{X}+877,212 \mathrm{X}^{2}$ & $0,742^{* *}$ \\
IAPAR 28-Igapó & $\mathrm{Y}=8,78454-102,957 \mathrm{X}+656,969 \mathrm{X}^{2}$ & $0,502^{*}$ \\
\hline
\end{tabular}

As cultivares tiveram comportamento diferenciado em relação à eficiência de utilização de zinco. Algumas delas apresentaram maior índice de eficiência 
no nível $0,025 \mathrm{mg} \mathrm{Zn} / \mathrm{l}$ e em outras a eficiência diminuiu a partir do nível zero até $0,100 \mathrm{mg} \mathrm{Zn/l}$ (Figura 16 e Tabela 29).

As cultivares Anahuac, BH 1146 e BR 20-Guató tiveram comportamento semelhante. Anahuac atingiu a máxima eficiência de utilização de zinco pela parte aérea com o nível de $0,019 \mathrm{mg} \mathrm{Zn} / \mathrm{l}$, enquanto que as cultivares $\mathrm{BH} 1146 \mathrm{e}$ BR 20-Guató foi com o nível de $0,025 \mathrm{mg} \mathrm{Zn/l} \mathrm{(Figura} 16$ e Tabela 29). A cultivar BR 18-Terena atingiu a máxima eficiência com o nível $0,036 \mathrm{mg} \mathrm{Zn} / \mathrm{l}$ e nos demais níveis ocorreram decréscimos (Figura 16a). EMBRAPA 10-Guajá, BR 36-Ianomami e IAC 13Lorena comportaram-se de maneira semelhante, com decréscimos a partir do nível zero $\mathrm{mg} \mathrm{Zn} / \mathrm{l}$ (Figura 16a e c). Na BR 31-Miriti a eficiência de utilização decresceu até o nível $0,064 \mathrm{mg} \mathrm{Zn/l} \mathrm{e} \mathrm{a} \mathrm{partir} \mathrm{desse} \mathrm{nível} \mathrm{permaneceu} \mathrm{praticamente} \mathrm{constante} \mathrm{(Figura} \mathrm{16a).}$ BR 30-Cadiuéu e IAC 18-Xavantes também tiveram comportamento semelhante, com decréscimos na eficiência de utilização de zinco até os níveis 0,090 e $0,085 \mathrm{mg} \mathrm{Zn/l}$ (Figura 16b e c). As cultivares IAPAR 6-Tapejara, IAPAR 17-Caeté e IAPAR 28-Igapó apresentaram decréscimos na eficiência de utilização até os níveis 0,$076 ; 0,077$ e 0,078 $\mathrm{mg} \mathrm{Zn/l,} \mathrm{respectivamente} \mathrm{(Figura} 16 \mathrm{~b} \mathrm{e} \mathrm{c).}$

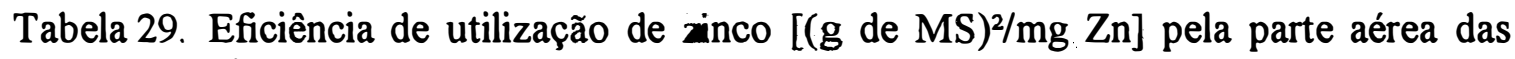
plantas.

\begin{tabular}{lrrrr}
\hline & \multicolumn{4}{c}{ Zinco (mg/l) } \\
\cline { 2 - 5 } Cultivar & 0,000 & 0,025 & 0,050 & 0,100 \\
\hline BH 1146 & $8,90 \mathrm{~b}$ & $13,01 \mathrm{a}$ & $9,97 \mathrm{~b}$ & $8,50 \mathrm{~b}$ \\
BR 17-Caiuá & $6,79 \mathrm{a}$ & $8,72 \mathrm{a}$ & $7,64 \mathrm{a}$ & $6,26 \mathrm{a}$ \\
BR 20-Guató & $7,95 \mathrm{~b}$ & $10,32 \mathrm{a}$ & $6,69 \mathrm{~b}$ & $6,66 \mathrm{~b}$ \\
\hline
\end{tabular}

Médias seguidas da mesma letra, na horizontal não diferem pelo teste de Duncan, ao nível de $5 \%$ de significância. 


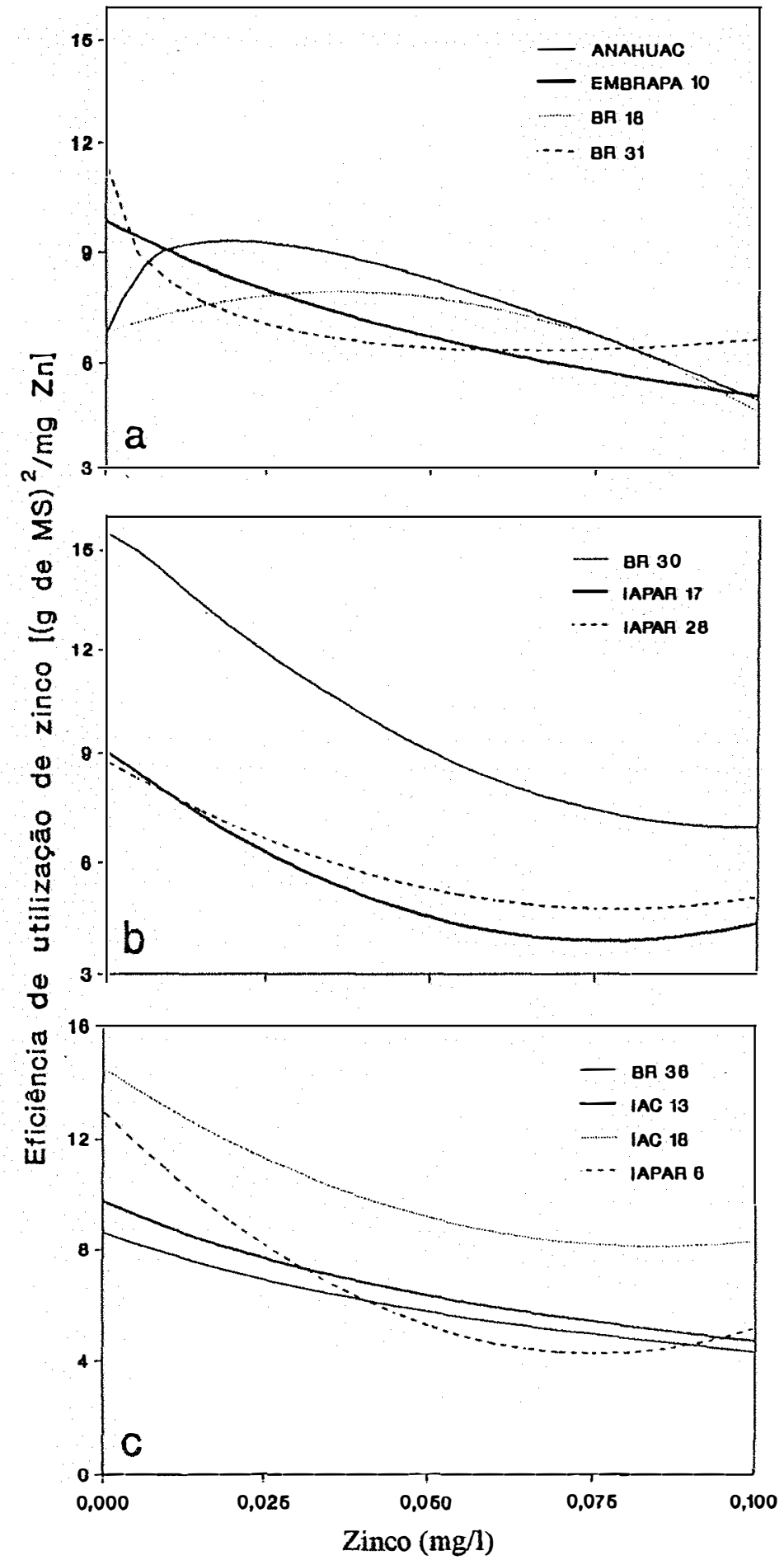

Figura 16. Eficiência de utilização de zinco pela parte aérea das plantas de trigo. 


\section{CONCLUSÕES}

Nas condições em que foram desenvolvidos os experimentos, os resultados obtidos permitem concluir que a adição de boro e zinco proporcionou aumentos dos teores desses elementos nos solos e nas plantas sem, no entanto, influir no rendimento de grãos. No Latossolo Roxo distrófico a adição de $0,8 \mathrm{mg} \mathrm{B} / \mathrm{dm}^{3}$ foi suficiente para obter rendimentos de massa seca de palha estatisticamente igual à dose máxima.

Nos experimentos na câmara de crescimento as cultivares responderam de modo diferenciado à adição de boro e zinco e aos níveis avaliados. Para a maioria delas, a eficiência de utilização de boro e zinco diminuiu com o aumento dos níveis dos nutrientes. No experimento com boro, as cultivares BR 10-Formosa e BR 17-Caiuá foram mais eficientes que as demais na utilização do nutriente. E, no experimento com zinco, as mais eficientes foram Anahuac e BR 18-Terena.

Com relação à produção de massa seca da parte aérea e das raízes, as cultivares mais produtivas, no experimento com boro, foram IAC 18-Xavantes, BR 17Caiuá, BR 20-Guató e BH 1146. E, no experimento com zinco, as mais produtivas foram BH 1146, IAC 18-Xavantes e BR 31-Miriti. 


\section{REFERÊNCIAS BIBLIOGRÁFICAS}

AHMAD, I.; KHATTAK, J.K.; PERVEEN, S. Effect of boron on the yield and crude protein content of wheat (Triticum aestivum L.). Pakistan Journal of Scientific and Industrial Research, Karachi, 22(5):248-50, Oct. 1979.

ASANA, R.D. \& WILLIAMS, R.F. The effect of temperature stress on grain development in wheat. Australian Journal of Agricultural Research, East Melbourne, 16:1-13, 1965.

AUBERT, H. \& PINTA, M. Trace elements in soils. Amsterdam, Elsevier, 1977. $395 p$.

BANSAL, R.L.; SINGH, S.P.; NAYYAR, V.K. The critical zinc deficiency level and response to zinc application of wheat on typic ustochsepts. Experimental Agriculture, Cambridge, 26:303-6, 1990.

BATAGLIA, O.C. \& RAIJ, B. van. Eficiência de extratores na determinação de boro em solos. Revista Brasileira de Ciência do Solo, Campinas, 14(1):25-31, jan./abr. 1990.

BRADFORD, G.R. Boron. In: CHAPMAN, H.D., ed. Diagnostic criteria for plants and soils. Riverside, University of California, 1966. p.33-61.

BRASIL SOBRINHO, M.O.C. Levantamento do teor de boro em alguns solos do Estado de São Paulo. Piracicaba, 1965. 135p. (Livre Docência. Escola Superior de Agricultura "Luiz de Queiroz"/USP). 
BROWN, A.L.; QUICK, J.; EDDINGS, J.L. A comparison of analytical methods for soil zinc. Soil Science Society of America Proceedings, Madison, 35(1):105-7, 1971.

CAMARGO, O.A.; MONIZ, A.C.; JORGE, J.A.; VALADARES, J.A.M.S. Métodos de análises química, mineralógica e física de solos do Instituto Agronômico. Campinas, IAC, 1986. 94p. (Boletim Técnico, 106).

CAMARGO, O.A.; VALADARES, J.M.A.S.; DECHEN, A.R. Efeitos do pH e da incubação na extração do manganês, zinco, cobre e ferro no solo. Revista Brasileira de Ciência do Solo, Campinas, 6(2):83-8, maio/ago. 1982.

CAMARGO, P.N. de \& SILVA, O. Manual de adubação foliar. São Paulo, La Libresia/Herba, 1975. 258p.

CAMPBELL, C.A. \& DAVIDSON, H.R. Effect of temperature, nitrogen fertilization and moisture stress on yield, yield components, protein content and moisture use efficiency of Manitou spring wheat. Canadian Journal of Plant Science, Ottawa, 59(4):963-74, Oct. 1979.

CARTWRIGHT, B.; TILLER, K.G.; ZARCINAS, B.A.; SPOUNCER, L.R. The chemical assessment of the boron status of soils. Australian Journal of Soil Research, East Melbourne, 21:321-32, 1983.

CASAGRANDE, J.C. O boro em solos do município de Piracicaba. Piracicaba, 1978. 122p. (Mestrado - Escola Superior de Agricultura "Luiz de Queiroz"/USP).

CHOWDHURY, S.I. \& WARDLAW, I.F. The effect of temperature on kernel development in cereals. Australian Journal of Agricultural Research, East Melbourne, 29(2):205-23, mar. 1978. 
COX, F.R. \& KAMPRATH, E.J. Micronutrient soil tests. In: MORTVEDT, J.J.; GIORDANO, P.M.; LINDSAY, W.L., ed. Micronutrients in agriculture. Madison, Soil Science Society of America, 1972. p.289-317.

DELL, B. \& WILSON, S.A. Effect of zinc supply on growth of three species of eucalyptus seedlings and wheat. Plant and Soil, Dordrecht, 88(3):377-84, 1985.

DENNIS, E.J. Micronutrientes: uma nova dimensão na agricultura. In: FUNDAÇÃO CARGILL. Micronutrientes. 2.ed. Campinas, Fundação Cargill, 1987. cap.1, p.3-20.

ELLIS, B.G. \& KNEZEK, B.D. Adsorption reactions of micronutrients in soils. In: MORTVEDT, J.J.; GIORDANO, P.M.; LINDSAY, W.L., ed. Micronutrients in agriculture. Madison, Soil Science Society of America, 1972. p.59-78.

EMBRAPA. Unidade de Execução de Pesquisa de Âmbito Estadual de Dourados (MS).

BR 17-Caiuá e BR 18-Terena: cultivares de trigo para Mato Grosso do Sul. Dourados, EMBRAPA-UEPAE Dourados/EMBRAPA-SPSB, 1987. If.

FAO (Roma, Itália). Crops. FAO. Production yearbook, Roma, 44:67-85, 1991.

FERREIRA, M.E. \& CRUZ, M.C.P. da. Seleção de extratores químicos para avaliação da disponibilidade de zinco em solos do estado de São Paulo. Pesquisa

Agropecuária Brasileira, Brasília, 27(2):293-304, fev. 1992.

FLEMING, G.A. Essential micronutrients I: boron and molybdenum. In: DAVIES, B.E., ed. Applied soil trace elements. Chichester, John Wiley, 1980. cap.5, p.155-97.

FLOSS, E.L. Avaliação da toxicidade do alumínio em genótipos de aveia. Piracicaba, 1992. 296p. (Doutorado-Escola Superior de Agricultura "Luiz de Queiroz"/USP). 
FURLANI, P.R. \& HANNA, L.G. Avaliação da tolerância de plantas de arroz e milho ao alumínio em solução nutritiva. Revista Brasileira de Ciência do Solo, Campinas, 8(2):205-8, maio/ago. 1984.

GALRÃO, E.Z. \& SOUSA, D.M.G. de. Efeito do boro na esterilidade masculina do trigo em um solo orgânico de várzea. Revista Brasileira de Ciência do Solo, Campinas, 12(2):147-52, maio/ago. 1988.

GUPTA, U.C. Interaction effects of boron and lime of barley. Soil Science Society of America Proceedings, Madison, 36(2):332-4, 1972.

GUPTA, U.C. Boron nutrition of crops. Advances in Agronomy, New York, 31:273$307,1979$.

GUPTA, U.C.; MACLEOD, J.A.; STERLING, J.D.E. Effects of boron and nitrogen on grain yield and boron and nitrogen concentrations of barley and wheat. Soil Science Society of America Journal, Madison, 40(5):723-6, Sep./Oct. 1976.

HODGSON, J.F.; LINDSAY, W.L.; TRIERWEILER, J.F. Micronutrient cation complexing in soil solution. II. Complexing of zinc and copper in displacing solution from calcareous soils. Soil Science Society of America Proceedings, Madison, 30:723-6, 1966.

HOROWITZ, A. \& DANTAS, H.S. Geoquímica dos elementos menores nos solos de Pernambuco. IV. Zinco na zona Litoral-Mata. Pesquisa Agropecuária Brasileira, Série Agronomia, Rio de Janeiro, 11(12):27-35, 1976.

HUNT, L.A.; POORTEN, G. van der; PARARAJASINGHAM, S. Postanthesis temperature effects on duration and rate of grain filling in some winter and spring wheats. Canadian Journal of Plant Science, Ottawa, 71(3):609-17, July 1991.

IBGE (Rio de Janeiro, RJ). Aspectos das atividades agropecuárias, extração vegetal e pesca. Anuário Estatístico do Brasil, Rio de Janeiro, 52:537-66, 1993. 
KABATA-PENDIAS, A. \& PENDIAS, H. Elements of group II. In: . Trace elements in soils and plants. Boca Raton, CRC Press, 1985a. cap.7, p.91-123.

KABATA-PENDIAS, A. \& PENDIAS, H. Elements of group III. In: Trace elements in soils and plants. Boca Raton, CRC Press, 1985b. cap.8, p.127-49.

KEREN, R.; BINGHAM, F.T.; RHOADES, J.D. Effect of clay content in soil on boron uptake and yield of wheat. Soil Science Society of America Journal, Madison, 49(6):1466-70, Nov./Dec. 1985.

KNEZEK, B.D. \& ELLIS, B.G. Essential micronutrients IV. Copper, iron, manganese and zinc. In: DAVIES, B., ed. Applied soil trace elements. Chichester, John Wiley, 1980. cap.8, p.259-86.

LINDSAY, W.L. Zinc in soils and plant nutrition. Advances in Agronomy. New York, 24:147-81, 1972.

LINDSAY, W.L. \& NORVELL, W.A. Development of a DTPA soil test for zinc, iron, manganese, and copper. Soil Science Society of America Journal, Madison, 42(3):421-8, May./Jun. 1978.

LOPES, A.S. Características e propriedades químicas da camada superficial $(0-20 \mathrm{~cm})$ dos solos sob «cerrado». In: Solos sob «cerrado»; características, propriedades e manejo. Piracicaba, Instituto da Potassa \& Fosfato; Instituto Internacional da Potassa, 1983. p.10-48.

LOPEZ RITAS, J. \& LOPEZ MELIDA, J. El diagnóstico de suelos e plantas: métodos de campo y laboratório. 3.ed. Madrid, Mundi-Prensa, 1978. 337p.

MALAVOLTA, E. Micronutrientes na adubação. São Paulo, Nutriplant Indústria e Comércio, 1986. 70p. 
MALAVOLTA, E. Nutrição mineral de plantas. In: CURSO DE ATUALIZAÇÃO EM FERTILIDADE DO SOLO, Ilha Solteira, 1987. Trabalhos apresentados. Campinas, Fundação Cargill, 1987. p.33-101. (Fundação Cargill, 128).

MALAVOLTA, E.; HAAG, H.P.; MELLO, F.A.F.; BRASIL SOBRINHO, M.O.C. Nutrição mineral e adubação de plantas cultivadas. São Paulo, Pioneira, 1974. $752 p$.

MALAVOLTA, E.; VITTI, G.C.; OLIVEIRA, S.A. de. Avaliação do estado nutricional das plantas; princípios e aplicações. Piracicaba, POTAFOS, 1989. $201 \mathrm{p}$.

MATO GROSSO DO SUL. Secretaria de Estado de Planejamento e de Ciência e Tecnologia. Classes de erodibilidade. In: Susceptibilidade à erosão da macrorregião da bacia do Paraná. Campo Grande, 1992. p.152-6.

MELSTED, S.W.; MOTTO, H.L.; PECK, T.R. Critical plant nutrient composition values useful in interpreting plant analysis data. Agronomy Journal, Madison, 61(1):17-20, Jan./Feb. 1969.

MITRA, A.K. \& JANA, P.K. Effect of doses and method of boron application on wheat in acid Terai soils of north Bengal. Indian Journal of Agronomy, New Delhi, 36(1):72-4, Mar. 1991.

MOTA, F.S. da. Clima e zoneamento para a triticultura no Brasil. In: FUNDAÇÃO CARGILL. Trigo no Brasil. Campinas, 1982. v.1, p.29-58.

OLSEN, S.R. Micronutrient interactions. In: MORTVEDT, J.J.; GIORDANO, P.M.; LINDSAY, W.L., ed. Micronutrients in agriculture. Madison, Soil Science Society of America, 1972. p.243-64.

PARARAJASINGHAM, S. \& HUNT, L.A. Wheat spike temperature in relation to base temperature for grain filling duration. Canadian Journal of Plant Science, Ottawa, 71(1):63-9, Jan. 1991. 
PAUL, J.G.; RATHJEN, A.J.; CARTWRIGHT, B. Tolerance to high concentrations of boron for the amphiploid of Triticum aestivum x Agropyron elongatum. Plant and Soil, Dordrecht, 133:297-9, 1991.

RAIJ, B. van. \& QUAGGIO, J.A. Métodos de análise de solo para fins de fertilidade. Campinas, IAC, 1983. 31p. (Boletim Técnico, 81).

RAJ, H. \& GUPTA, V.K. Effect of organic manures, lime and zinc on growth and zinc nutrition of wheat. Journal of the Indian Society of Soil Science, New Delhi, 34(3):639-40, 1986.

RASHID, A. \& FOX, R.L. Evaluating internal requeriments of grain crops by seed analysis. Agronomy Journal, Madison, 84(3):469-74, May/June 1992.

REEVE, E. \& SHIVE, J.W. Potassium-boron and calcium-boron relationships in plant nutrition. Soil Science, Baltimore, 57:1-14, 1944.

SIDDIQI, M.Y. \& GLASS, A.D.M. Utilization index: a modified approach to the estimation and comparasion of nutrient utilization efficiency in plants. Journal of Plant Nutrition, New York, 4(3):289-302, 1981.

SILVA, A.R. da \& ANDRADE, J.M.V. de. Efeito de micronutrientes no chochamento do trigo de sequeiro e nas culturas de soja e arroz, em Latossolo VermelhoAmarelo. Pesquisa Agropecuária Brasileira, Brasília, 18(6):593-601, jun. 1983.

SIMS, J.R. \& BINGHAM, F.T. Retention of boron by layer silicates, sesquioxides, and soil materials. I. Layer silicates. Soil Science Society of America Proceedings, Madison, 31:728-32, 1967.

SINGH, A.P.; SAKAL, R.; THAKUR, K.N.; SINHA, H. Response of wheat to zinc and its critical level in Old Alluvium soils. Journal of Agricultural Science, Cambridge, 95(1):175-9, Aug. 1980. 
SINHA, N.P.; SINGH, R.; PRASAD, B. Uptake of zinc by different varieties of wheat as influenced by zinc carriers in calcareious soil. The Madras Agricultural Journal, Coimbatore, 71(1):25-31, 1984.

SOFIELD, I.; EVANS, L.T ; COOK, M.G.; WARDLAN, I.F. Factors influencing the rate and duration of grain filling in wheat. Australian Journal of Plant Physiology, East Melbourne, 4(5):785-97, 1977.

SPIERTZ, J.H.J. Grain growth and distribution of dry matter in the wheat plant as influenced by temperature, light energy and ear size. Netherland Journal of Agricultural Science, Wageningen, 22:207-20, 1974.

TISDALE, S.L.; NELSON, W.L.; BEATON, J.D. Micronutrients and other beneficial elements in soils and fertilizers. In: Soil fertility and fertilizers. 4.ed. New York, MacMillan, 1985. cap.9, p.350-413.

TOLLENAAR, M.; MIHALLOVIC, M.; AGUILERA, A. Temperature response of dry matter accumulation, leaf photosynthesis, and chlorophyll fluorescence in old and new maize hybrid during early development. Canadian Journal of Plant Science, Ottawa, 71(2):353-9, Apr. 1991.

VALADARES, J.M.A.S. \& CATANI, R.A. Zinco em solos do Estado de São Paulo. I. Zinco total. In: CONGRESSO BRASILEIRO DE CIÊNCIA DO SOLO, 14., Santa Maria, 1973. Anais. Santa Maria, Universidade Federal de Santa Maria; Sociedade Brasileira de Ciência do Solo, 1974. p.291-3.

VIETS JUNIOR, F.G. \& LINDSAY, W.L. Testing soils for zinc, copper, manganese, and iron. In: WALSH, L.M.; BEATON, J.D., ed. Soils testing and plant analysis. Madison, Soil Science Society of America, 1983. p.153-72.

WIEGAND, C.L. \& CUELLAR, J.A. Duration of grain filling and kernel weight of wheat as affected by temperature. Crop Science, Madison, 21(1):95-101, Jan./Feb. 1981. 
YADAV, O.P. \& MANCHANDA, H.R. Boron tolerance studies in gram and wheat grown on a sierozem sand soil. Journal of the Indian Society of Soil Science, New Delhi, 27(2):174-80, 1979. 
APÊNDICE 
Apêndice 1. Análise de variância do comprimento da parte aérea do experimento com boro em câmara de crescimento.

\begin{tabular}{lrrrrr}
\hline Causas da variação & G.L. & \multicolumn{1}{c}{ S.Q. } & Q.M. & F & Prob. > F \\
\hline Blocos & 2 & 24,6547619 & & & \\
Niveis de boro (PP) & 3 & 442,5952381 & 147,5317460 & 22,1232 & 0,00188 \\
Residuo (A) & 6 & 40,0119048 & 6,6686508 & & \\
\hline Parcelas & 11 & 507,2619048 & & & \\
Cultivares (SP) & 13 & 689,8095238 & 53,0622711 & 26,1953 & 0,00001 \\
PP x SP & 39 & 118,2380952 & 3,0317460 & 1,4967 & 0,05505 \\
Residuo (B) & 104 & 210,6666667 & 2,0256410 & & \\
\hline Total & 167 & 1525,9761905 & & & \\
\hline
\end{tabular}

Coeficiente de variação $(A)=2,857 \% \quad$ Média geral $=24,154762$

Coeficiente de variação $(B)=5,892 \%$

1

Apêndice 2. Análise de variância do comprimento da raiz do experimento com boro em câmara de crescimento.

\begin{tabular}{lrrrrr}
\hline Causas da variação & G.L. & \multicolumn{1}{c}{ S.Q. } & Q.M. & F & Prob. > F \\
\hline Blocos & 2 & 39,1904762 & & & \\
Niveis de boro (PP) & 3 & 4560,9047619 & 1520,3015873 & 1,7795 & 0,25056 \\
Resíduo (A) & 6 & 5125,9523810 & 854,3253968 & & \\
\hline Parcelas & 11 & 9726,0476190 & & & \\
Cultivares (SP) & 13 & 4535,1190476 & 348,8553114 & 34,4377 & 0,00001 \\
PP x SP & 39 & 822,9285714 & 21,1007326 & 2,0830 & 0,00197 \\
Resíduo (B) & 104 & 1053,5238095 & 10,1300366 & & \\
\hline Total & 167 & $16.137,6190476$ & & & \\
\hline
\end{tabular}

Coeficiente de variação $(\mathrm{A})=13,676 \% \quad$ Média geral $=57,119049$

Coeficiente de variação $(B)=5,572 \%$ 
Apêndice 3. Análise de variância do teor de boro na massa seca da parte aérea das plantas no experimento em câmara de crescimento.

\begin{tabular}{lrrrrr}
\hline Causas da variação & G.L. & S.Q. & Q.M. & F & Prob. > F \\
\hline Blocos & 2 & 32903,0833333 & & & \\
Niveis de boro (PP) & 3 & 341013,5714286 & 113671,1904762 & 96,5385 & 0,00017 \\
Residuo (A) & 6 & 7064,8214286 & 1177,4702381 & & \\
\hline Parcelas & 11 & 380981,4761905 & & & \\
Cultivares (SP) & 13 & 35091,4047619 & 2699,3388278 & 4,4780 & 0,00003 \\
PP x SP & 39 & 32474,2619048 & 832,6733822 & 1,3814 & 0,10028 \\
Residuo (B) & 104 & 62690,7619048 & 602,7957875 & & \\
\hline Total & 167 & 511237,9047619 & & & \\
\hline
\end{tabular}

Coeficiente de variação $(A)=9,601 \% \quad$ Média geral $=95,523800$

Coeficiente de variação $(B)=25,702 \%$

Apêndice 4. Análise de variância do teor de boro na massa seca das raízes no experimento em câmara de crescimento.

\begin{tabular}{lrrrrr}
\hline Causas da variação & \multicolumn{1}{c}{ G.L. } & S.Q. & Q.M. & F & Prob. > F \\
\hline Blocos & 2 & 424465,5833333 & & & \\
Níveis de boro (PP) & 3 & 83205,7797619 & 27735,2599206 & 4,7109 & 0,05129 \\
Resíduo (A) & 6 & 35324,5595238 & 5887,4265873 & & \\
\hline Parcelas & 11 & 542995,9226190 & & & \\
Cultivares (SP) & 13 & 41669,0297619 & 3205,3099817 & 1,3774 & 0,18250 \\
PP x SP & 39 & 107501,4702381 & 2756,4479548 & 1,1845 & 0,24694 \\
Resíduo (B) & 104 & 242011,8571429 & 2327,0370879 & & \\
\hline Total & 167 & 934178,2797619 & & & \\
\hline
\end{tabular}


Apêndice 5. Análise de variância da produção de massa seca da parte aérea das plantas no experimento em câmara de crescimento.

\begin{tabular}{lcclll}
\hline Causas da variação & G.L. & S.Q. & Q.M. & F & Prob. > F \\
\hline Blocos & 2 & 0,0460714 & & & \\
Níveis de boro (PP) & 3 & 0,0263690 & 0,0087897 & 5,7532 & 0,03414 \\
Resíduo (A) & 6 & 0,0091667 & 0,0015278 & & \\
\hline Parcelas & 11 & 0,0816071 & & & \\
Cultivares (SP) & 13 & 1,0319643 & 0,0793819 & 30,4158 & 0,00001 \\
PP x SP & 39 & 0,1344643 & 0,0034478 & 1,3211 & 0,13454 \\
Resíduo (B) & 104 & 0,2714286 & 0,0026099 & & \\
\hline Total & 167 & 1,5194642 & & & \\
\hline
\end{tabular}

Coeficiente de variação $(A)=3,0 \% \quad$ Média geral $=0,348214$

Coeficiente de variação $(B)=14,671 \%$

Apêndice 6. Análise de variância da produção de massa seca das raízes das plantas no experimento em câmara de crescimento.

\begin{tabular}{lccccr}
\hline Causas da variação & G.L. & S.Q. & Q.M. & F & Prob. > F \\
\hline Blocos & 2 & 0,0067857 & & & \\
Níveis de boro (PP) & 3 & 0,1861905 & 0,0620635 & 21,8741 & 0,00193 \\
Resíduo (A) & 6 & 0,0170238 & 0,0028373 & & \\
\hline Parcelas & 11 & 0,2100000 & & & \\
Cultivares (SP) & 13 & 0,4111905 & 0,0316300 & 21,0610 & 0,00001 \\
PP x SP & 39 & 0,1054762 & 0,0027045 & 1,8008 & 0,00982 \\
Resíduo (B) & 104 & 0,1561905 & 0,0015018 & & \\
\hline Total & 167 & 0,8828571 & & & \\
\hline
\end{tabular}

Coeficiente de variação $(\mathrm{A})=4,429 \% \quad$ Média geral $=0,321429$

Coeficiente de variação $(B)=12,057 \%$ 
Apêndice 7. Análise de variância do acúmulo de boro pela parte aérea das plantas no experimento em câmara de crescimento.

\begin{tabular}{lrrrrr}
\hline Causas da variação & G.L. & \multicolumn{1}{c}{ S.Q. } & Q.M. & F & Prob. > F \\
\hline Blocos & 2 & 253,1329434 & & & \\
Níveis de boro (PP) & 3 & 55310,3998416 & 18436,7999472 & 512,4635 & 0,00004 \\
Residuo (A) & 6 & 215,8608287 & 35,9768048 & & \\
\hline Parcelas & 11 & 55779,3936137 & & & \\
Cultivares (SP) & 13 & 9544,2359200 & 734,1719938 & 11,8340 & 0,00001 \\
PP x SP & 39 & 9805,0430879 & 251,4113612 & 4,0525 & 0,00001 \\
Resíduo (B) & 104 & 6452,0856616 & 62,0392852 & & \\
\hline Total & 167 & 81580,7582832 & & & \\
\hline
\end{tabular}

Coeficiente de variação $(\mathrm{A})=4,854 \% \quad$ Média geral $=33,0256$

Coeficiente de variação $(B)=23,850 \%$

Apêndice 8. Análise de variância do acúmulo de boro pelas raízes das plantas no experimento em câmara de crescimento.

\begin{tabular}{lrrrrr}
\hline Causas da variação & G.L. & \multicolumn{1}{c}{ S.Q. } & Q.M. & F & Prob. $>$ F \\
\hline Blocos & 2 & 807,6968294 & & & \\
Niveis de boro. (PP) & 3 & 18523,1842638 & 6174,3947546 & 20,5971 & 0,00218 \\
Residuo (A) & 6 & 1798,6234042 & 299,7705674 & & \\
\hline Parcelas & 11 & 21129,5044974 & & & \\
Cultivares (SP) & 13 & 25528,3256151 & 1963,7173550 & 20,0591 & 0,00001 \\
PP x SP & 39 & 41084,3238082 & 1053,4442002 & 10,7608 & 0,00001 \\
Resíduo (B) & 104 & 10181,2669155 & 97,8967973 & & \\
\hline Total & 167 & 97923,4208363 & & & \\
\hline
\end{tabular}

Coeficiente de variação $(A)=9,113 \% \quad$ Média geral $=50,7768$

Coeficiente de variação $(B)=19,486 \%$ 
Apêndice 9. Análise de variância da eficiência de utilização de boro pelas plantas no experimento em câmara de crescimento.

\begin{tabular}{lrrrrr}
\hline Causas da variação & G.L. & \multicolumn{1}{c}{ S.Q. } & Q.M. & F & Prob. > F \\
\hline Blocos & 2 & 88,0200188 & & & \\
Niveis de boro (PP) & 3 & 2526,4290972 & 842,1430324 & 30,1774 & 0,00103 \\
Residuo (A) & 6 & 167,4385430 & 27,9064238 & & \\
\hline Parcelas & 11 & 2781,8876590 & & & \\
Cultivares (SP) & 13 & 1261,2729194 & 97,0209938 & 18,9891 & 0,00001 \\
PP x SP & 39 & 2989,4981956 & 76,6537999 & 15,0028 & 0,00001 \\
Residuo (B) & 104 & 531,3674585 & 5,1093025 & & \\
\hline Total & 167 & 7564,0262325 & & & \\
\hline
\end{tabular}

Coeficiente de variação $(\mathrm{A})=23,591 \% \quad$ Média geral $=5,9847$

Coeficiente de variação $(B)=37,769 \%$

Apêndice 10. Análise de variância do comprimento da parte aérea do experimento com zinco em câmara de crescimento.

\begin{tabular}{lrrrrr}
\hline Causas da variação & G.L. & S.Q. & Q.M. & F & Prob. > F \\
\hline Blocos & 2 & 40,9404762 & & & \\
Niveis de zinco (PP) & 3 & 39,2619048 & 13,0873016 & 1,1489 & 0,40365 \\
Residuo (A) & 6 & 68,3452381 & 11,3908730 & & \\
\hline Parcelas & 11 & 148,5476190 & & & \\
Cultivares (SP) & 13 & 763,1666667 & 58,7051282 & 16,2355 & 0,00001 \\
PP x SP & 39 & 133,0714286 & 3,4120879 & 0,9436 & 0,56990 \\
Residuo (B) & 104 & 376,0476190 & 3,6158425 & & \\
\hline Total & 167 & 1420,8333333 & & & \\
\hline
\end{tabular}

Coeficiente de variação $(A)=3,936 \% \quad$ Média geral $=22,916700$

Coeficiente de variação $(B)=8,298 \%$ 
Apêndice 11. Análise de variância do comprimento da raiz do experimento com zinco em câmara de crescimento.

\begin{tabular}{lrrrrr}
\hline Causas da variação & G.L. & S.Q. & Q.M. & F & Prob. > F \\
\hline Blocos & 2 & 36,7500000 & & & \\
Níveis de zinco (PP) & 3 & 227,3511905 & 75,7837302 & 0,5970 & 0,64198 \\
Residuo (A) & 6 & 761,6309524 & 126,9384921 & & \\
\hline Parcelas & 11 & 1025,7321429 & & \\
Cultivares (SP) & 13 & 2456,2916667 & 188,9455128 & 28,5774 & 0,00001 \\
PP x SP & 39 & 193,7321429 & 4,9674908 & 0,7513 & 0,84324 \\
Resíduo (B) & 104 & 687,6190476 & 6,6117216 & & \\
\hline Total & 167 & & 4363,3750000 & & \\
\hline
\end{tabular}

Coeficiente de variação $(\mathrm{A})=8,057 \% \quad$ Média geral $=37,375000$

Coeficiente de variação $(B)=6,880 \%$

Apêndice 12. Análise de variância do teor de zinco na massa seca da parte aérea no experimento em câmara de crescimento.

\begin{tabular}{lrrrrr}
\hline Causas da variação & G.L. & S.Q. & Q.M. & F & Prob. > F \\
\hline Blocos & 2 & 147,0000000 & & & \\
Níveis de zinco (PP) & 3 & 12841,2857143 & 4280,4285714 & 140,7815 & 0,00011 \\
Resíduo (A) & 6 & 182,4285714 & 30,4047619 & & \\
\hline Parcelas & 11 & 13170,7142857 & & & \\
Cultivares (SP) & 13 & 2683,2380952 & 206,4029304 & 5,8080 & 0,00001 \\
PP x SP & 39 & 3762,7142857 & 96,4798535 & 2,7149 & 0,00009 \\
Resíduo (B) & 104 & 3695,9047619 & 35,5375458 & & \\
\hline Total & 167 & 23312,5714286 & & & \\
\hline
\end{tabular}

Coeficiente de variação $(A)=3,915 \% \quad$ Média geral $=37,642900$

Coeficiente de variação $(B)=15,837 \%$ 
Apêndice 13. Análise de variância do teor de zinco na massa seca das raízes no experimento em câmara de crescimento.

\begin{tabular}{lrrrrr}
\hline Causas da variação & G.L. & \multicolumn{1}{c}{ S.Q. } & Q.M. & F & Prob. > F \\
\hline Blocos & 2 & 2593,8571429 & & & \\
Níveis de zinco (PP) & 3 & 52296,5892857 & 17432,1964286 & 19,6398 & 0,00240 \\
Residuo (A) & 6 & 5325,5714286 & 887,5952381 & & \\
\hline Parcelas & 11 & 60216,0178571 & & & \\
Cultivares (SP) & 13 & 15476,8630952 & 1190,5279304 & 12,0624 & 0,00001 \\
PP x SP & 39 & 15036,4940476 & 385,5511294 & 3,9064 & 0,00001 \\
Resíduo (B) & 104 & 10264,5714886 & 98,6978022 & & \\
\hline Total & 167 & 100993,9464286 & & & \\
\hline
\end{tabular}

Coeficiente de variação $(A)=15,456 \% \quad$ Média geral $=51,517900$

Coeficiente de variação $(B)=19,284 \%$

Apêndice 14. Análise de variância da massa seca da parte aérea do experimento com zinco em câmara de crescimento.

\begin{tabular}{lcclll}
\hline Causas da variação & G.L. & S.Q. & Q.M. & F & Prob. > F \\
\hline Blocos & 2 & 0,0001869 & & & \\
Níveis de zinco (PP) & 3 & 0,0363256 & 0,0121085 & 3,2798 & 0,10062 \\
Residuo (A) & 6 & 0,0221512 & 0,0036919 & & \\
\hline Parcelas & 11 & 0,0586637 & & & \\
Cultivares (SP) & 13 & 0,1983768 & 0,0152598 & 9,6890 & 0,00001 \\
PP x SP & 39 & 0,0585494 & 0,0015013 & 0,9532 & 0,55506 \\
Resíduo (B) & 104 & 0,1637952 & 0,0015750 & & \\
\hline Total & 167 & 0,4793851 & & & \\
\hline
\end{tabular}

Coeficiente de variação $(\mathrm{A})=5,899 \% \quad$ Média geral $=0,275298$ Coeficiente de variação $(B)=14,416 \%$ 
Apêndice 15. Análise de variância da massa seca das raízes do experimento com zinco em câmara de crescimento.

\begin{tabular}{lccccc}
\hline Causas da variação & G.L. & S.Q. & Q.M. & F & Prob. > F \\
\hline Blocos & 2 & 0,0030619 & & & \\
Niveis de zinco (PP) & 3 & 0,0014714 & 0,0004905 & 0,1942 & 0,89629 \\
Residuo (A) & 6 & 0,0151571 & 0,0025262 & & \\
\hline Parcelas & 11 & 0,0196905 & & & \\
Cultivares (SP) & 13 & 0,0632619 & 0,0048663 & 8,6590 & 0,00001 \\
PP x SP & 39 & 0,0183619 & 0,0004708 & 0,8378 & 0,73094 \\
Resíduo (B) & 104 & 0,0584476 & 0,0005620 & & \\
\hline Total & 167 & 0,1597619 & & & \\
\hline
\end{tabular}

Coeficiente de variação $(\mathrm{A})=\mathbf{8 , 9 8 4} \% \quad$ Média geral $=0,149524$

Coeficiente de variação $(B)=15,855 \%$

Apêndice 16. Análise de variância do acúmulo de zinco na parte aérea das plantas no experimento em câmara de crescimento.

\begin{tabular}{lrrrrr}
\hline Causas da variação & G.L. & \multicolumn{1}{c}{ S.Q. } & Q.M. & F & Prob. > F \\
\hline Blocos & 2 & 4,6428825 & & & \\
Níveis de zinco (PP) & 3 & 1289,4850708 & 429,8283569 & 41,4652 & 0,00059 \\
Resíduo (A) & 6 & 62,1959730 & 10,3659955 & & \\
\hline Parcelas & 11 & 1356,3239263 & & & \\
Cultivares (SP) & 13 & 327,5354886 & 25,1950376 & 4,9240 & 0,00001 \\
PP x SP & 39 & 363,6653292 & 9,3247520 & 1,8224 & 0,00867 \\
Resíduo (B) & 104 & 532,1426020 & 5,1167558 & & \\
\hline Total & 167 & 2579,6673461 & & & \\
\hline
\end{tabular}

Coeficiente de variação $(A)=8,160 \% \quad$ Média geral $=10,544900$

Coeficiente de variação $(B)=21,451 \%$ 
Apêndice 17. Análise de variância do acúmulo de zinco nas raízes no experimento em câmara de crescimento.

\begin{tabular}{|c|c|c|c|c|c|}
\hline Causas da variação & G.L. & S.Q. & Q.M. & $\mathrm{F}$ & Prob. $>\mathrm{F}$ \\
\hline Blocos & 2 & 40,3684762 & & & \\
\hline Níveis de zinco (PP) & 3 & 1560,6668260 & 520,2222753 & 30,7176 & 0,00100 \\
\hline Resíduo (A) & 6 & 101,6137194 & 16,9356199 & & \\
\hline Parcelas & 11 & 1702,6490216 & & & \\
\hline Cultivares (SP) & 13 & 1073,6875632 & 82,5913510 & 21,3320 & 0,00001 \\
\hline$P P \times S P$ & 39 & 622,4383524 & 15,9599578 & 4,1222 & 0,00001 \\
\hline Resíduo (B) & 104 & 402,6579768 & 3,8717113 & & \\
\hline Total & 167 & 3801,4329140 & & & \\
\hline
\end{tabular}

Coeficiente de variação $(\mathrm{A})=13,657 \% \quad$ Média geral $=8,053510$

Coeficiente de variação $(B)=24,432 \%$

Apêndice 18. Análise de variância da eficiência de utilização de zinco no experimento em câmara de crescimento.

\begin{tabular}{lrrrrr}
\hline Causas da variação & G.L. & \multicolumn{1}{c}{ S.Q. } & Q.M. & F & Prob. > F \\
\hline Blocos & 2 & 8,8845083 & & & \\
Níveis de zinco (PP) & 3 & 419,5285204 & 139,8428401 & 24,4873 & 0,00154 \\
Resíduo (A) & 6 & 34,2650562 & 5,7108427 & & \\
\hline Parcelas & 11 & 462,6780849 & & & \\
Cultivares (SP) & 13 & 387,0582567 & 29,7737121 & 12,2773 & 0,00001 \\
PP x SP & 39 & 334,0392565 & 8,5651091 & 3,5319 & 0,00001 \\
Residuo (B) & 104 & 252,2107150 & 2,4251030 & & \\
\hline Total & 167 & 1435,9863131 & & & \\
\hline
\end{tabular}

Coeficiente de variação $(\mathrm{A})=7,987 \% \quad$ Média geral $=7,996370$

Coeficiente de variação $(B)=19,475 \%$ 